\title{
Ethanol Demand in United States Regional Production of Oxygenate-limited Gasoline
}

\author{
G. R. Hadder \\ Center for Transportation Analysis \\ Oak Ridge National Laboratory \\ Oak Ridge, Tennessee
}

\author{
August 2000 \\ Prepared for \\ Office of Fuels Development \\ Office of Transportation Technologies \\ U.S. Department of Energy \\ Prepared by the \\ OAK RIDGE NATIONAL LABORATORY \\ Oak Ridge, Tennessee 37831 \\ managed by \\ UT-BATTELLE, LLC \\ for the \\ U. S. DEPARTMENT OF ENERGY \\ under contract DE-AC05-00OR22725
}





\section{TABLE OF CONTENTS}

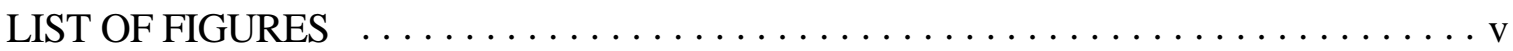

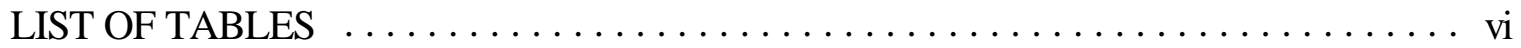

ACRONYMS AND ABBREVIATIONS $\ldots \ldots \ldots \ldots \ldots \ldots \ldots \ldots \ldots \ldots \ldots$ vii

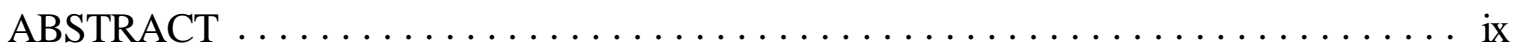

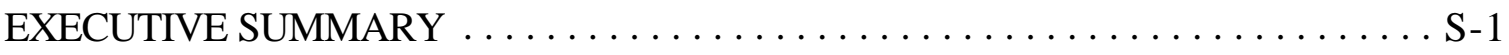

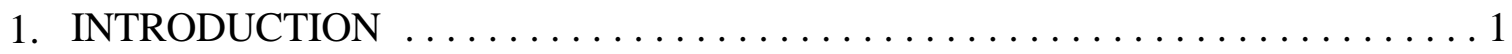

2. THE ORNL REFINERY YIELD MODEL $\ldots \ldots \ldots \ldots \ldots \ldots \ldots \ldots \ldots \ldots$

3. THE ORNL-RYM REPRESENTATION OF CLEANER GASOLINES $\ldots \ldots \ldots \ldots 7$

3.1 FORMULA AND EMISSIONS STANDARDS $\ldots \ldots \ldots \ldots \ldots \ldots \ldots$

3.2 REPRESENTATION OF NON-LINEAR EMISSIONS MODELS IN A

LINEAR PROGRAM $\ldots \ldots \ldots \ldots \ldots \ldots \ldots \ldots \ldots \ldots \ldots \ldots \ldots$

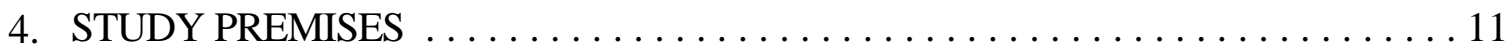

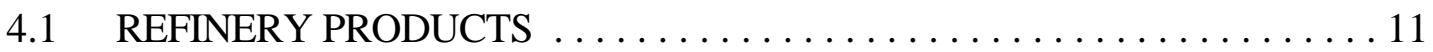

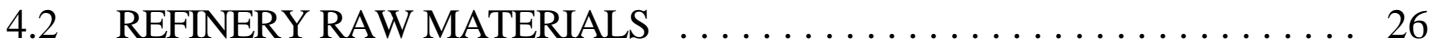

4.3 PRODUCT REVENUES AND RAW MATERIAL COSTS $\ldots \ldots \ldots \ldots .27$

4.4 FEDERAL TAX IMPLICATIONS FOR ETHANOL CONCENTRATIONS ............................. 27

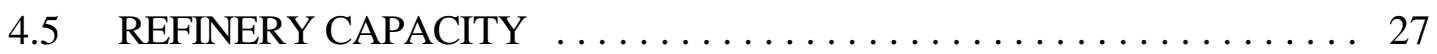

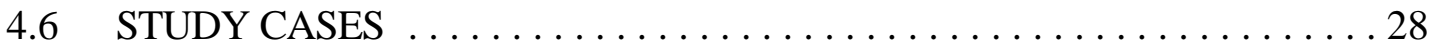

5. THE DEMAND FOR ETHANOL USED IN U.S. REGIONAL OXYGENATELIMITED GASOLINE PRODUCTON IN YEAR 2006 ................. 31

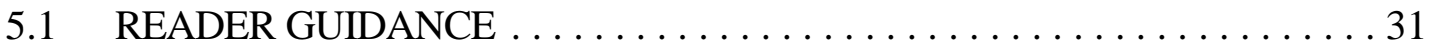

5.2 PADD I+III, SUMMER REFERENCE CONDITIONS $\ldots \ldots \ldots \ldots \ldots . \ldots 31$

5.3 PADD I+III, SUMMER WITH 3 PERCENT MAXIMUM MTBE . . . . . . 54

5.4 PADD I+III, WINTER WITH 3 PERCENT MAXIMUM MTBE . . . . . . 56 
5.5 PADD I+III, ANNUAL WITH 3 PERCENT MAXIMUM MTBE . . . . . . . 58

5.6 PADD II, SUMMER REFERENCE CONDITIONS . . . . . . . . . . . . . . 60

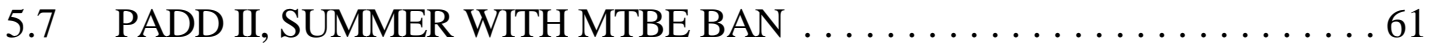

5.8 PADD II, WINTER WITH MTBE BAN . . . . . . . . . . . . . 62

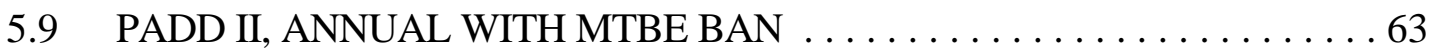

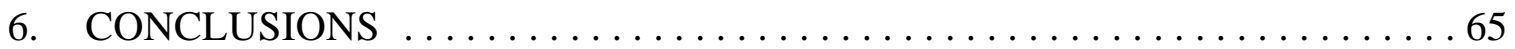

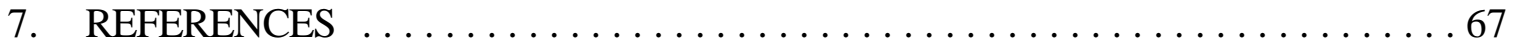




\section{LIST OF FIGURES}

Fig. S-1. Annual ethanol demand with reduced MTBE in PADD I+III gasoline type production, Year 2006 - 3\% max MTBE - 30 ppm sulfur

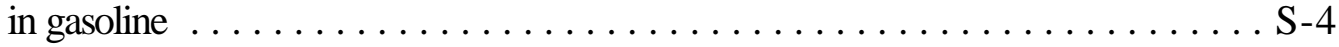

Fig. S-2. Annual ethanol demand with MTBE ban in PADD II gasoline type production, Year 2006 - 30 ppm sulfur in gasoline . . . . . . . . . . . . S-4

Fig. 1. Oxygenate demand in Reference case PADD I+III gasoline production, Year 2006 summer - 30 ppm sulfur in gasoline . . . . . . . . . . . . . . 32

Fig. 2. Ethanol demand in Reference case PADD I+III gasoline type production, Year 2006 summer - 30 ppm sulfur in gasoline . . . . . . . . . . . . . . . . . 54

Fig. 3. Ethanol demand with reduced MTBE in PADD I+III gasoline production, Year 2006 summer - 3\% max MTBE - 30 ppm sulfur in gasoline . . . . . . . . . 55

Fig. 4. Octane value in PADD I+III gasoline production, Year 2006 summer - $30 \mathrm{ppm}$ sulfur in gasoline . . . . . . . . . . . . . . . . . . 56

Fig. 5. Seasonal ethanol demand with reduced MTBE in PADD I+III gasoline production, Year 2006 - 3\% max MTBE - 30 ppm sulfur in gasoline . . . . . . . 57

Fig. 6. Seasonal ethanol demand with reduced MTBE in PADD I+III production of gasoline with no low sulfur requirement, Year 2006 - 3\% max MTBE . . . . . 58

Fig. 7. Blendstock tradeoffs with reduced MTBE in PADD I+III winter gasoline production, Year 2006 - 3\% max MTBE - 30 ppm sulfur in gasoline . . . . . . 58

Fig. 8. Annual ethanol demand with reduced MTBE in PADD I+III gasoline production, Year 2006 summer - 3\% max MTBE - 30 ppm sulfur in gasoline . . . . . . . . . . . . . . . . . . . . . . . . 59

Fig. 9. Annual ethanol demand with reduced MTBE in PADD I+III gasoline type production, Year 2006 summer - 3\% max MTBE - 30 ppm sulfur in gasoline . . . . . . . . . . . . . . . . . . . . . . . . . . 59

Fig. 10. Oxygenate demand in Reference case PADD II gasoline production, Year 2006 summer - 30 ppm sulfur in gasoline . . . . . . . . . . . . . . 60

Fig. 11. Ethanol demand in Reference case PADD II gasoline type production, Year 2006 summer -30 ppm sulfur in gasoline . . . . . . . . . . . . . . 61

Fig. 12. Ethanol demand in PADD II gasoline production, Year 2006 summer - 30 ppm sulfur in gasoline . . . . . . . . . . . . . . . . . 62

Fig. 13. Ethanol demand with MTBE ban in PADD II gasoline production, Year 2006 summer - 30 ppm sulfur in gasoline . . . . . . . . . . . . . . . . . 63

Fig. 14. Seasonal ethanol demand with MTBE ban in PADD II gasoline production, Year 2006 summer - no low sulfur requirement for gasoline . . . . . . . . . . . 64

Fig. 15. Annual ethanol demand with MTBE ban in PADD II gasoline production, Year 2006 - 30 ppm sulfur in gasoline 


\section{LIST OF TABLES}

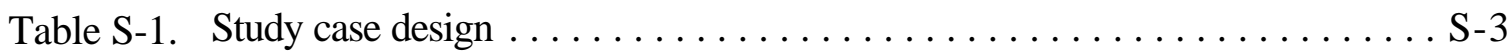

Table 1. Formula and emissions performance standards for the federal RFG

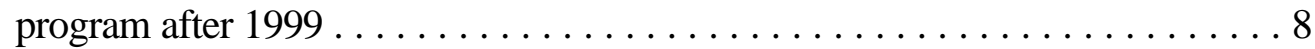

Table 2. PADD I+III raw materials and products for year 2006 summer Reference conditions ............................. 12

Table 3. PADD I+III process capacity for year 2006 summer Reference conditions ................................... 13

Table 4. PADD I+III raw materials and products for year 2006 summer

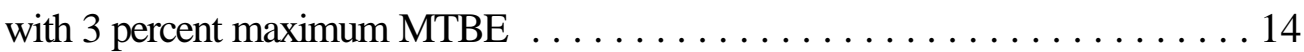

Table 5. PADD I+III process capacity for year 2006 summer with 3 percent

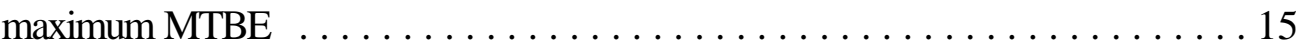

Table 6. PADD I+III raw materials and products for year 2006 winter with 3 percent maximum MTBE . .......................... 16

Table 7. PADD I+III process capacity for year 2006 winter with 3 percent

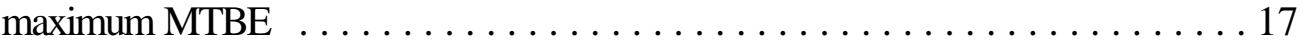

Table 8. PADD II raw materials and products for year 2006 summer Reference conditionk8

Table 9. PADD II process capacity for year 2006 summer Reference conditions . . . . . 19

Table 10. PADD II raw materials and products for year 2006 summer MTBE ban . . . . 20

Table 11. PADD II process capacity for year 2006 summer MTBE ban . . . . . . . . 21

Table 12. PADD II raw materials and products for year 2006 winter MTBE ban . . . . . 22

Table 13. PADD II process capacity for year 2006 winter MTBE ban . . . . . . . . 23

Table 14. PADD I+ III specifications for emissions performance standards for

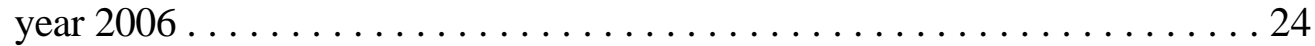

Table 15. PADD II specifications for emissions performance standards for

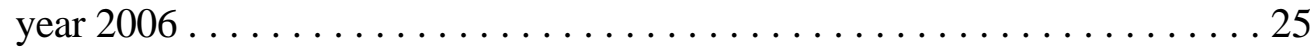

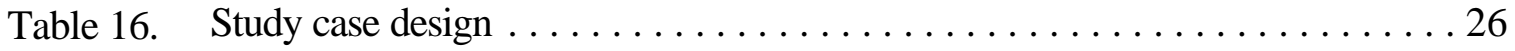

Table 17. Gasoline properties ................................. 33

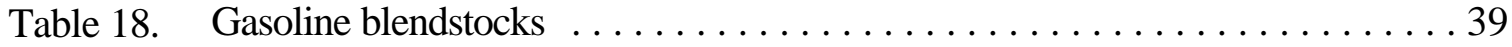

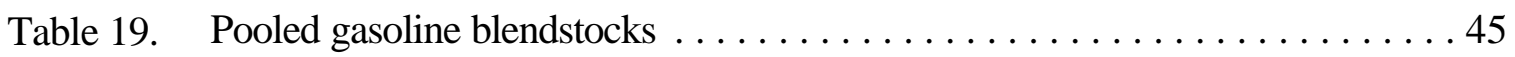

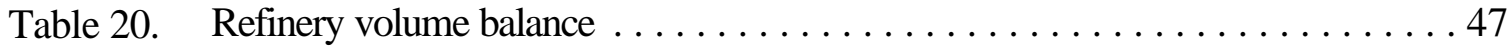

Table 21. Hydrogen balance for refineries . . . . . . . . . . . . . . . . . . . 49

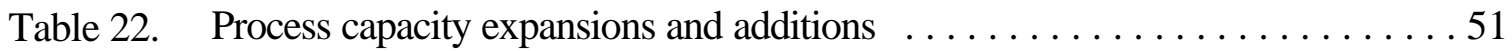

Table 23. Cost of process capacity expansions and additions $\ldots \ldots \ldots \ldots \ldots \ldots . \ldots \ldots 2$

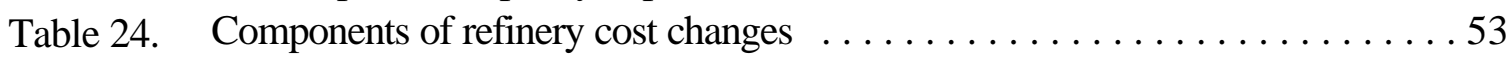

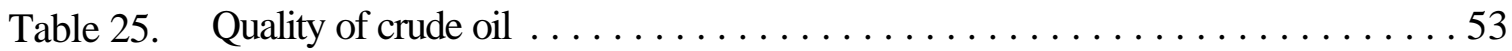




\section{ACRONYMS AND ABBREVIATIONS}

\begin{tabular}{|c|c|}
\hline $\mathrm{AEO}$ & Annual Energy Outlook \\
\hline API & American Petroleum Institute \\
\hline ASTM & American Society for Testing and Materials \\
\hline BGY & Billion gallons per year \\
\hline CAAA & Clean Air Act Amendments of 1990 \\
\hline $\mathrm{CG}$ & Conventional gasoline \\
\hline $\mathrm{C} 4 \mathrm{~s}$ & Butane and related 4-carbon molecules \\
\hline DCF & Discounted cash flow \\
\hline DOE & Department of Energy \\
\hline EIA & Energy Information Administration \\
\hline EPA & Environmental Protection Agency \\
\hline $\mathrm{EtOH}$ & Ethanol \\
\hline E200 & The cumulative volume percent evaporated at $200^{\circ} \mathrm{F}$ in ASTM test \\
\hline & D86-87: Distillation of Petroleum Products \\
\hline $\mathrm{E} 300$ & The cumulative volume percent evaporated at $300^{\circ} \mathrm{F}$ in ASTM test \\
\hline & D86-87: Distillation of Petroleum Products \\
\hline $\mathrm{F}$ & Fahrenheit \\
\hline FCC & Fluid catalytic cracking \\
\hline FOE & Fuel oil equivalent \\
\hline FY & Fiscal year \\
\hline LSG & Low sulfur gasoline \\
\hline M & Motor octane number \\
\hline $\max$ & Maximum \\
\hline $\mathrm{MBD}$ & Thousand barrels per day \\
\hline MBCD & Thousand barrels per calendar day \\
\hline MBPD & Thousand barrels per day \\
\hline MBSD & Thousand barrels per stream day \\
\hline $\mathrm{mg} / \mathrm{mi}$ & Milligrams per mile \\
\hline
\end{tabular}




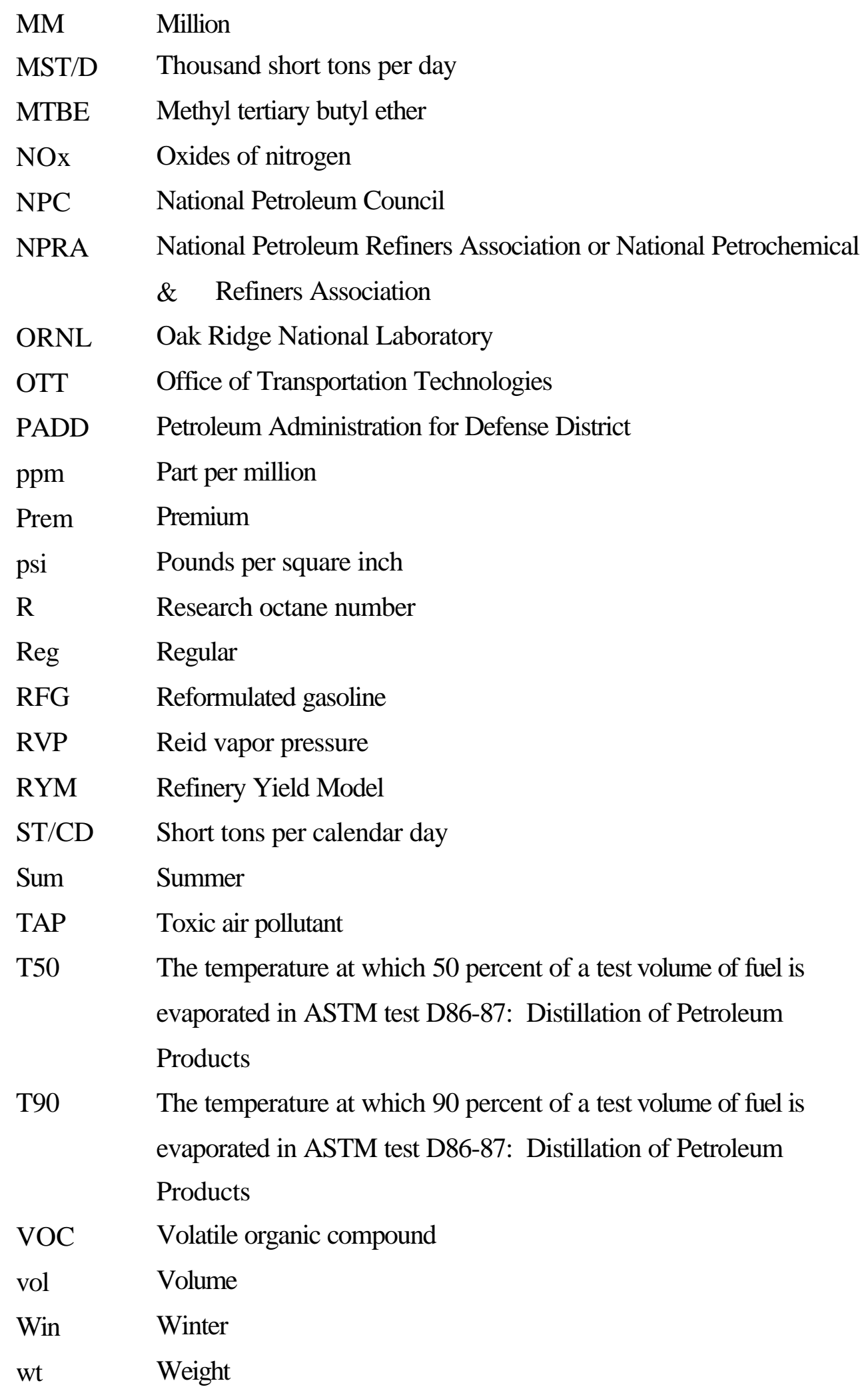




\begin{abstract}
Ethanol competes with methyl tertiary butyl ether (MTBE) to satisfy oxygen, octane, and volume requirements of certain gasolines. However, MTBE has water quality problems that may create significant market opportunities for ethanol. Oak Ridge National Laboratory (ORNL) has used its Refinery Yield Model to estimate ethanol demand in gasolines with restricted use of MTBE. Reduction of the use of MTBE would increase the costs of gasoline production and possibly reduce the gasoline output of U.S. refineries. The potential gasoline supply problems of an MTBE ban could be mitigated by allowing a modest 3 vol percent MTBE in all gasoline. In the U.S. East and Gulf Coast gasoline producing regions, the 3 vol percent MTBE option results in costs that are 40 percent less than an MTBE ban. In the U.S. Midwest gasoline producing region, with already high use of ethanol, an MTBE ban has minimal effect on ethanol demand unless gasoline producers in other regions bid away the local supply of ethanol. The ethanol/MTBE issue gained momentum in March 2000 when the Clinton Administration announced that it would ask Congress to amend the Clean Air Act to provide the authority to significantly reduce or eliminate the use of MTBE; to ensure that air quality gains are not diminished as MTBE use is reduced; and to replace the existing oxygenate requirement in the Clean Air Act with a renewable fuel standard for all gasoline. Premises for the ORNL study are consistent with the Administration announcement, and the ethanol demand curve estimates of this study can be used to evaluate the impact of the Administration principles and related policy initiatives.
\end{abstract}




\section{EXECUTIVE SUMMARY}

The Energy Policy Act of 1992 (the Act) outlined a national energy strategy that called for reducing the nation's dependency on petroleum imports. The Act directed the Secretary of Energy to establish a program to promote and expand the use of renewable fuels. The Office of Transportation Technologies (OTT) within the U.S. Department of Energy (DOE) has evaluated a wide range of potential fuels and has concluded that cellulosic ethanol is one of the most promising near-term prospects. Ethanol is widely recognized as a clean fuel that helps reduce emissions of toxic air pollutants. Furthermore, cellulosic ethanol produces less greenhouse gas emissions than gasoline or any of the other alternative transportation fuels being considered by DOE.

Most ethanol is now produced from corn. While some growth in the corn-based ethanol industry is anticipated, its expansion is constrained by the competing food uses of corn. DOE believes that cellulosic ethanol technology has the potential to significantly increase domestic ethanol production and is currently funding research to advance cellulosic ethanol conversion techniques. Cellulosic ethanol can be produced from agricultural residues and biocrops specifically designed for the energy market.

Ethanol has the potential to displace petroleum in two distinct markets. The blend market is characterized by gasoline/ethanol mixtures containing 10 percent or less ethanol by volume. The neat market is characterized by ethanol/gasoline mixtures containing 85 percent or more ethanol by volume. The blend market has significant advantages with respect to early market penetration. First, gasoline/ethanol blends can be used in all gasoline-powered automobiles and light trucks on the road today. Neat ethanol fuels require specially adapted engines and can be used in only a small percent of the current vehicle fleet. Second, ethanol blends are compatible with the existing retail infrastructure. Because of the need for separate service station tanks and pumps, neat ethanol fuels will require substantial infrastructure investments. Third, ethanol used in blends is valued as an octane enhancer and an oxygenate. Ethanol used in neat fuels will have to compete with gasoline on a mileage or energy content basis, but ethanol has only about two-thirds the energy content of gasoline.

Ethanol competes with methyl tertiary butyl ether (MTBE) to satisfy oxygen, octane, and volume requirements of certain gasolines. However, MTBE has water quality problems that may create significant market opportunities for ethanol. The use of MTBE in the reformulated gasoline (RFG) program has resulted in growing detections of MTBE in drinking water, with between 5 percent and 10 percent of community drinking water supplies in high oxygenate use areas showing at least detectable amounts of MTBE. There have been important debates about the air quality benefits and water quality problems of MTBE. In November, 1998, the 
U.S. Environmental Protection Agency (EPA) Administrator appointed a Blue Ribbon Panel to investigate the air quality benefits and water quality concerns associated with oxygenates in gasoline. The Panel generally agreed that less MTBE should be used in the reformulated gasoline program. Given the Panel recommendations, the EPA Administrator announced that "We must begin to significantly reduce the use of MTBE in gasoline as quickly as possible without sacrificing the gains we've made in achieving cleaner air."

In support of the Office of Fuels Development in the DOE OTT, Oak Ridge National Laboratory (ORNL) has used its refinery yield model (ORNL-RYM) to estimate ethanol demand in gasolines with restricted use of oxygenates. ORNL-RYM is a linear program representing 50 refining processes which can be used to produce 40 different products from more than 100 crude oils. An investment module provides for the addition of processing capacity. ORNL-RYM tracks a comprehensive set of gasoline properties, including formula and emissions standards required by the Clean Air Act Amendments of 1990.

If there is a mandated reduction of MTBE in gasoline, some MTBE could be replaced by highoctane, high toxicity, high-aromatics gasoline blendstocks. With current gasolines emitting less than the statutory limits for toxic air pollutants, it is possible that toxic air pollutants could increase with these high-aromatics replacement blendstocks. This study assumes that new regulations will not allow "toxics-backsliding" (no increase of toxics above recently observed levels). With toxics-backsliding not allowed, low toxicity blendstocks like alkylates are likely to be favored over high-aromatics replacement stocks.

Data for the study are based on information published by DOE, the U.S. Energy Information Administration, the National Petroleum Council, the National Petrochemical \& Refiners Association, and industry journals. The study design is shown in Table S-1. Study cases estimate refinery demand curves for ethanol in a low sulfur gasoline world; with or without a partial or full ether ban; and with or without an oxygen content specification.

There are three key premises for the ethanol demand study. First, it is assumed that gasoline blending is optimized, with minimum giveaway of gasoline quality. Modeled refineries can produce subgrade gasolines for shipment to blenders who add optimal volumes of ethanol to produce finished gasoline. Second, ethanol handling and logistics costs in refining/blending are assumed to be 5 cents per gallon. Third, it is assumed that consumers are indifferent to ethanol blends, neither seeking nor avoiding these gasolines.

Ethanol demand is analyzed for gasoline production in Petroleum Administration for Defense District I (PADD I, the U.S. East Coast), PADD II (U.S. Midwest) and PADD III (U.S. Gulf Coast). These regions account for about 80 percent of U.S. gasoline production. Annualized ethanol demand curves for the regions are shown in Figs. S-1 and S-2. 
Table S-1. Study case design

\begin{tabular}{|c|c|c|c|c|c|c|}
\hline Case & 1 & 2 & 3 & 4 & 5 & 6 \\
\hline General & $\begin{array}{c}\text { Referenc } \\
\mathrm{e}\end{array}$ & $\begin{array}{l}3 \% \text { vol } \\
\max \\
\text { MTBE }\end{array}$ & $\begin{array}{l}3 \% \text { vol } \\
\max \\
\text { MTBE }\end{array}$ & Reference & Ether Ban & Ether Ban \\
\hline Region & $\begin{array}{c}\text { East/Gulf } \\
\text { Coasts }\end{array}$ & $\begin{array}{c}\text { East/Gulf } \\
\text { Coasts }\end{array}$ & $\begin{array}{c}\text { East/Gulf } \\
\text { Coasts }\end{array}$ & Midwest & Midwest & Midwest \\
\hline Year & 2006 & 2006 & 2006 & 2006 & 2006 & 2006 \\
\hline Season & Sum & Sum & Win & Sum & Sum & Win \\
\hline $\begin{array}{l}\text { RFG } \\
\text { oxygen } \\
w_{t} \%{ }^{a, b}\end{array}$ & $2.1-2.7$ & $\begin{array}{l}0-3.5(\mathrm{E}) \\
<0.5(\mathrm{M})\end{array}$ & $\begin{array}{l}0-3.5(\mathrm{E}) \\
<0.5(\mathrm{M})\end{array}$ & $2.1-3.5$ & $0-3.5$ & $0-3.5$ \\
\hline $\begin{array}{l}\mathrm{CG} \\
\text { oxygen } \\
\mathrm{wt} \%{ }^{\mathrm{a}}\end{array}$ & $0-2.7$ & $0-3.5$ & $0-3.5$ & $0-3.5$ & $0-3.5$ & $0-3.5$ \\
\hline $\begin{array}{l}\text { Vol percent } \\
\text { ethanol in } \\
\mathrm{CG}^{\mathrm{c}}\end{array}$ & N/A & 10 & 10 & 10 & 10 & 10 \\
\hline $\begin{array}{l}\text { Gasoline } \\
\text { oxygenate }\end{array}$ & MTBE & $\begin{array}{l}\text { EtOH } \\
\text { MTBE }\end{array}$ & $\begin{array}{l}\text { EtOH } \\
\text { MTBE }\end{array}$ & $\begin{array}{l}\text { EtOH } \\
\text { MTBE }\end{array}$ & $\mathrm{EtOH}$ & $\mathrm{EtOH}$ \\
\hline $\begin{array}{l}\text { Gasoline } \\
\text { pools }^{\text {b }}\end{array}$ & $\begin{array}{c}\text { CG-M } \\
\text { CG-E } \\
\text { RFG-M-R } \\
\text { RFG-M-P } \\
\text { RFG-E-R } \\
\text { RFG-E-P }\end{array}$ & $\begin{array}{c}\text { CG-M } \\
\text { CG-E } \\
\text { RFG-M-R } \\
\text { RFG-M-P } \\
\text { RFG-E-R } \\
\text { RFG-E-P }\end{array}$ & $\begin{array}{c}\text { CG-M } \\
\text { CG-E } \\
\text { RFG-M-R } \\
\text { RFG-M-P } \\
\text { RFG-E-R } \\
\text { RFG-E-P }\end{array}$ & $\begin{array}{c}\text { CG-M } \\
\text { CG-E } \\
\text { RFG-M-R } \\
\text { RFG-M-P } \\
\text { RFG-E-R } \\
\text { RFG-E-P }\end{array}$ & $\begin{array}{c}\text { CG-N } \\
\text { CG-E } \\
\text { RFG-N-R } \\
\text { RFG-N-P } \\
\text { RFG-E-R } \\
\text { RFG-E-P }\end{array}$ & $\begin{array}{c}\text { CG-N } \\
\text { CG-E } \\
\text { RFG-N-R } \\
\text { RFG-N-P } \\
\text { RFG-E-R } \\
\text { RFG-E-P }\end{array}$ \\
\hline RFG share & \multicolumn{6}{|c|}{ Current } \\
\hline $\begin{array}{l}\text { Economic } \\
\text { premises }\end{array}$ & \multicolumn{6}{|c|}{ DOE Reference } \\
\hline $\begin{array}{l}\text { Ethanol } \\
\text { cost }\end{array}$ & N/A & Vary & Vary & Vary & Vary & Vary \\
\hline Other & \multicolumn{6}{|c|}{ Ratio-free refinery model/ low sulfur gasoline/ no toxics backsliding } \\
\hline
\end{tabular}




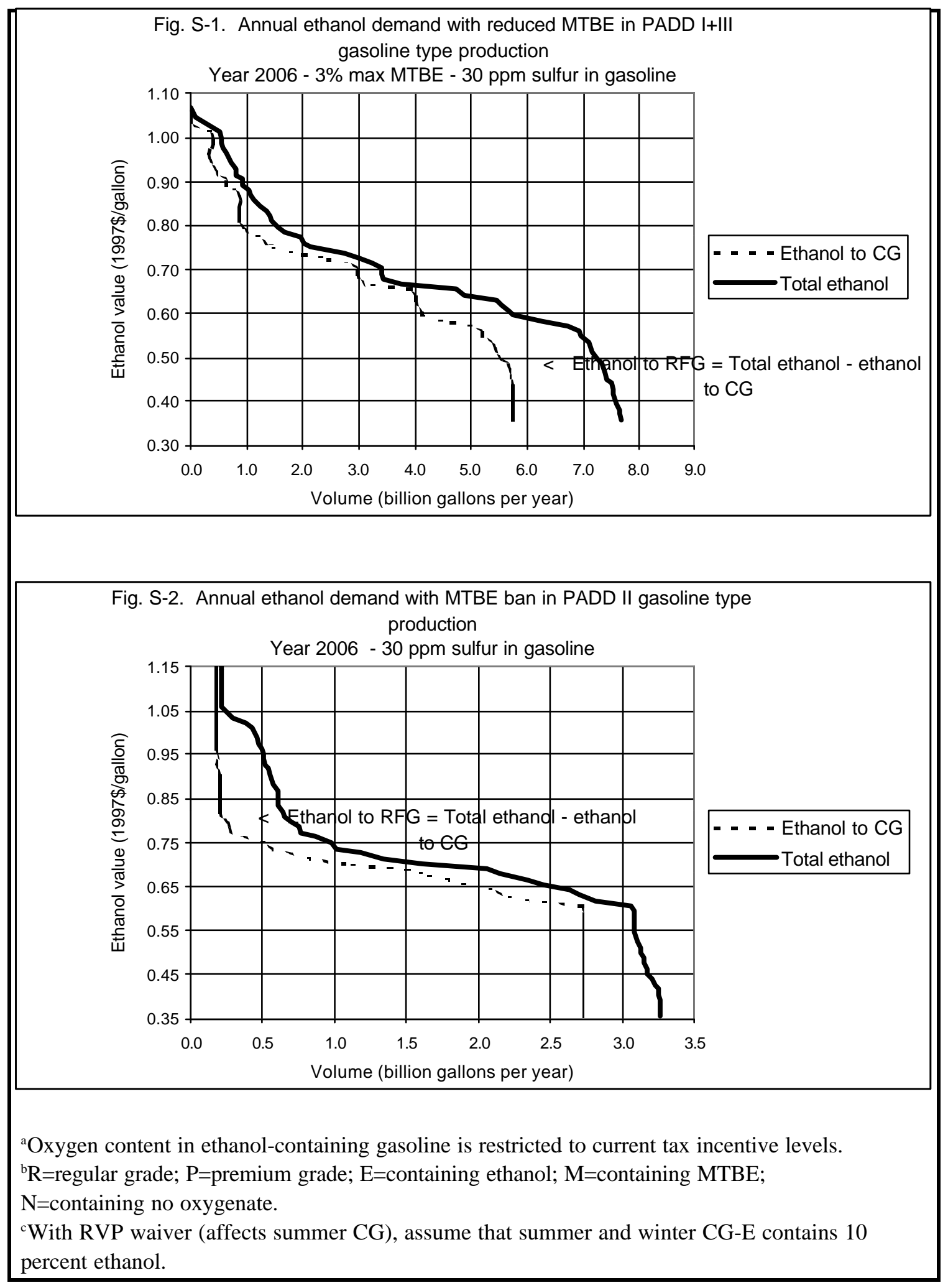


Marginal cost results show that volatility limits make summer RFG more difficult to produce with high-Reid vapor pressure (RVP) oxygenates like ethanol. Ethanol's value in conventional gasoline (CG) is enhanced by the 1 pound per square inch RVP waiver for 10 percent ethanol blends, and CG is typically the source of greatest demand for ethanol over the range of ethanol values.

Reduction of the use of MTBE would increase the costs of gasoline production and possibly reduce the gasoline output of U.S. refineries. MTBE is the dominant oxygenate in RFG, and gasoline production has evolved to depend on the attractive octane and volatility characteristics of MTBE. DOE has reported that elimination of MTBE is equivalent to a loss of up to 5 percent of the U.S. gasoline supply, when the octane-yield trade-offs for the replacement blendstocks are taken into account.

The potential gasoline supply problems of an MTBE ban could be mitigated by allowing a modest 3 vol percent MTBE in all gasoline. In PADD I+III, a 3 vol percent MTBE option results in costs that are 40 percent less than an MTBE ban. Major contributors to increased costs for a ban of MTBE are control of octane, volatility, and prevention of backsliding of toxic air pollutant emissions.

With a drop in MTBE production, more C4s (butane and related 4-carbon molecules) become available. Absent conversion of MTBE plants to production technologies that utilize isobutylene, ethanol is the primary substitute for MTBE in the summer. However, in the winter, ethanol may have to compete with directly-blended C4s.

PADD II has the highest regional use of ethanol, which provides about 90 percent of the total oxygenate volume now blended to that region's gasoline. Furthermore, the production share of RFG in PADD II is relatively low. Consequently, over much of ethanol's value range, a reduction in MTBE does not substantially change ethanol demand in PADD II gasoline production. An MTBE ban in PADD II gasoline production results in a cost increase of only 0.3 cents per gallon of RFG.

The ethanol/MTBE issue gained momentum in March 2000 when the Clinton Administration announced that it would ask Congress to amend the Clean Air Act to provide the authority to significantly reduce or eliminate the use of MTBE; to ensure that air quality gains are not diminished as MTBE use is reduced; and to replace the existing oxygenate requirement in the Clean Air Act with a renewable fuel standard for all gasoline.

The premises for this ORNL study are consistent with the Administration announcement, and the ethanol demand curve estimates of this study can be used to evaluate the impact of the Administration principles and related policy initiatives. 
S-6 


\section{INTRODUCTION}

The Energy Policy Act of 1992 outlined a national energy strategy that called for reducing the nation's growing dependency on imported petroleum. Recognizing the need to develop alternative transportation fuels, the Act directed the Secretary of Energy to establish a program to promote and expand the use of renewable fuels. The Office of Transportation Technologies (OTT) within the U.S. Department of Energy (DOE) has evaluated a wide range of potential fuels and has concluded that cellulosic ethanol is one of the most promising near-term prospects. Ethanol is a proven and publicly accepted fuel that has been used in the United States since the 1970s. It is widely recognized as a clean fuel that helps reduce emissions of toxic air pollutants. Furthermore, cellulosic ethanol produces less greenhouse gas emissions than gasoline, or for that matter, any of the other alternative transportation fuels being considered by DOE.

About 1.5 billion gallons per year (BGY) of ethanol are currently used in gasoline blends. Most of this ethanol is now produced from corn. While some growth in the corn-based ethanol industry is anticipated, its expansion is constrained by the competing uses of corn as a food crop. DOE believes that cellulosic ethanol technology has the potential to significantly increase domestic ethanol production and is currently funding research to advance cellulosic ethanol conversion techniques. Cellulosic ethanol can be produced from agricultural residues and genetically engineered biocrops specifically designed for the energy market.

Ethanol has the potential to displace petroleum in two distinct markets. The blend market is characterized by gasoline/ethanol mixtures containing 10 percent or less ethanol by volume. The neat market is characterized by ethanol/gasoline mixtures containing 85 percent or more ethanol by volume.

The blend market has significant advantages with respect to early market penetration. First, gasoline/ethanol blends can be used in all gasoline-powered automobiles and light trucks on the road today. Neat ethanol fuels require specially adapted engines and can be used in only a small percent of the current vehicle fleet. Second, ethanol blends are compatible with the existing service station infrastructure. Because of the need for separate service station tanks and pumps, neat ethanol fuels will require substantial infrastructure investments. Third, ethanol used in blends is valued as an octane enhancer and an oxygenate and not just for its energy content. Ethanol used in neat fuels will have to compete with gasoline on a mileage or energy content basis. Ethanol has about two-thirds the energy content of gasoline (Andress and Hadder, 1999). 
Ethanol competes with methyl tertiary butyl ether (MTBE) to satisfy oxygen, octane, and volume requirements of certain gasolines. However, MTBE has water quality problems that may create significant market opportunities for ethanol. The use of MTBE in the reformulated gasoline (RFG) program has resulted in growing detections of MTBE in drinking water, with between 5 percent and 10 percent of community drinking water supplies in high oxygenate use areas showing at least detectable amounts of MTBE. The great majority of these detections to date have been well below levels of public health concern, with approximately one percent rising to levels above 20 parts per billion. Detections at lower levels have, however, raised consumer taste and odor concerns that have caused water suppliers to stop using some water supplies and to incur costs of treatment and remediation. Private wells have also been contaminated, and these wells are less protected than public drinking water supplies and not monitored for chemical contamination. There is also evidence of contamination of surface waters, particularly during summer boating seasons.

The major source of groundwater contamination appears to be releases from underground gasoline storage systems. These systems have been upgraded over the last decade, likely resulting in reduced risk of leaks. However, approximately 20 percent of the storage systems have not yet been upgraded, and there continue to be reports of releases from some upgraded systems, due to inadequate design, installation, maintenance, and/or operation. In addition, many fuel storage systems (e.g., farms, small above-ground tanks) are not currently regulated by the U.S. Environmental Protection Agency (EPA). Beyond groundwater contamination from underground storage tank sources, the other major sources of water contamination appear to be small and large gasoline spills to ground and surface waters, and recreational water craft, particularly those with older motors, releasing unburned fuel to surface waters (U.S. EPA, 1999). There have been important debates about the air quality benefits and water quality problems of MTBE:

In November, 1998, EPA Administrator Carol M. Browner appointed a Blue Ribbon Panel to investigate the air quality benefits and water quality concerns associated with oxygenates in gasoline, and to provide independent advice and recommendations on ways to maintain air quality while protecting water quality. The Panel, which met six times from January - June 1999, heard presentations in Washington, the Northeast, and California about the benefits and concerns related to RFG and the oxygenates; gathered the best available information on the program and its effects; identified key data gaps; and evaluated a series of alternative recommendations based on their effects on air and water quality and the stability of fuel supply and cost (O'Keefe, 1999). The Panel agreed broadly, but not unanimously, that less MTBE should be used in the RFG program. Among many recommendations, the Panel urged the removal of the legal requirement that RFG contain 2 weight (wt) percent oxygen. Given the Panel recommendations, the EPA Administrator announced that "We must begin to significantly reduce the use of MTBE in gasoline as quickly as possible 
without sacrificing the gains we've made in achieving cleaner air" (Oil \& Gas Journal, 1999).

On November 9, 1998, New Hampshire Governor Jeanne Shaheen requested, on behalf of the New England Governor's Conference, that the Northeast States for Coordinated Air Use Management (NESCAUM) "Review the use and effectiveness of MTBE as a pollution reducing component of reformulated gasoline, consider what effective alternatives may exist that are consistent with statutory options or requirements, and make recommendations regarding the best course for the [Northeast] region to pursue in order to maximize air quality benefits and minimize public health threats." In August 1999, NESCAUM published recommendations for a multi-component strategy that includes legislative and regulatory initiatives to reduce the amount of MTBE in gasoline (NESCAUM, 1999).

On March 25, 1999, California Governor Gray Davis certified that there is significant risk to California's environment associated with continued use of MTBE in gasoline. He directed appropriate state regulatory agencies to devise and carry out a plan to begin immediate phase out of MTBE from California gasoline, with 100 percent removal achieved no later than December 31, 2002.

In Fiscal Year 1996 (FY96), DOE studied pathways for the corn ethanol industry to evolve into a biomass ethanol industry under two predetermined ethanol market share scenarios. Instead of using market assumptions, DOE's follow-up studies in FY97-99 started from "square one," and included a blend demand analysis, a neat demand analysis, and account for competition from gasoline, other alternative fuels, and oxygenates such as MTBE. Refinery modeling was used to estimate the blend demand for ethanol (Hadder, 1998). Given the concerns about the use of MTBE in gasoline, Oak Ridge National Laboratory (ORNL) has used its Refinery Yield Model (ORNL-RYM), in support of the Office of Fuels Development in the DOE OTT, to estimate ethanol demand in the production of gasolines with restricted use of oxygenates. 


\section{THE ORNL REFINERY YIELD MODEL}

ORNL-RYM is an enhanced personal computer version of the Refinery Yield Model of the Refinery Evaluation Modeling System (U.S. DOE, 1984a; U.S. DOE, 1984b; Tallett and Dunbar, 1988; Tallett et al., 1992). The refinery model is a linear program representing 50 refining processes (including new naphtha desulfurization technologies and other updates) which can be used to produce 40 different products from more than 100 crude oils. An investment module provides for the addition of processing capacity. ORNL-RYM tracks octane, Reid vapor pressure (RVP), oxygen content, sulfur, benzene, aromatics, total olefins, distillation points, and pollutant emissions on all gasoline component streams. In separate data tables in ORNL-RYM, gasoline blending components are identified; blending values are assigned to these components; and blending targets are set. Properties for distillates and jet fuels are handled in a similar fashion. ORNL-RYM incorporates gasoline blending to satisfy formula and emissions standards described by the EPA Complex Model, which predicts pollutant emissions in terms of gasoline properties (Korotney, 1993).

Overoptimization can occur as a result of ORNL-RYM's use of a modeling concept in which refinery hydrocarbon streams with identical distillation cut points are kept separate through different refining processes. Overoptimization of hydrocarbon processing tends to depress the use of ethanol in gasoline blending in the model (Hadder, 1998). Ratio constraints on refinery streams can be used to avoid unrealistic separation of streams with identical distillation cut points. With ratio constraints, the proportions of streams entering a process are constrained to equal the proportions of those streams produced at a source process. However, it has been demonstrated that the use of ratio constraints in regional refinery modeling can over-correct the stream separation problem, leading to overestimation of ethanol used in gasoline blending.

It is important to recognize that refineries within a region can vary widely in technical capability, and that refineries are subject to temporal variations in complex operations. Refining costs span a range, and this range has uncertainty. Given variations, uncertainties, and over/underoptimization possibilities, DOE has concluded that both ratio-free and ratioconstrained versions of ORNL-RYM can provide plausible estimates of the range of refining activities. The ratio-free model has been used in this study, for more conservative estimation of ethanol demand. 


\section{THE ORNL-RYM REPRESENTATION OF CLEANER GASOLINES}

\subsection{FORMULA AND EMISSIONS STANDARDS}

ORNL-RYM represents gasoline blending to satisfy formula and emissions standards mandated by the Clean Air Act Amendments of 1990 (CAAA). The CAAA include programs for oxygenated gasoline and for RFG. The oxygenated gasoline program requires that gasoline with a minimum oxygen content of $2.7 \mathrm{wt}$ percent be sold during winter months in cities not in compliance with carbon monoxide standards. RFG is required in nine areas with extreme or severe ozone pollution problems, and fifteen additional areas have chosen to voluntarily opt-in to the RFG program. The formula and emissions performance standards for RFG produced after 1999 are shown in Table 1 (U.S. EPA, 1994).

Emissions modeling provides a means for predicting the emissions performance of a gasoline, given other properties of the gasoline. The EPA Complex Model is a set of non-linear equations that predicts emissions of volatile organic compounds (VOCs), toxic air pollutants (TAPs), and oxides of nitrogen (NOx) in terms of gasoline properties including RVP, E200, E300, benzene, oxygen, sulfur, aromatics, and olefins contents (Korotney, 1993). The Complex Model has been used since March 1, 1997, to certify the emissions performance of gasolines.

While RFG accounts for about 33 percent of the nation's gasoline market, all gasolines are affected by the CAAA. Besides requiring RFG in the covered ozone nonattainment areas, the CAAA require that gasoline in all other areas not be any more polluting than it was in 1990. Without this "anti-dumping" provision, the potential exists for emissions from conventional gasoline (CG) to worsen as polluting fuel components are removed from RFG.

If there is a mandated reduction of MTBE in gasoline, some MTBE could be replaced by highoctane, high toxicity, high-aromatics gasoline blendstocks. With current gasolines emitting less than the statutory limits for toxic air pollutants, it is possible that toxic air pollutants could increase with these high-aromatics replacement blendstocks. This study assumes that new regulations will not allow "toxics-backsliding" (no increase of toxics above recently observed levels). With toxics-backsliding not allowed, low toxicity blendstocks like alkylates are likely to be favored over high-aromatics replacement stocks. 
Table 1. Formula and emissions performance standards for the federal RFG program after 1999

\begin{tabular}{|c|c|}
\hline Standard & $\begin{array}{l}\text { Phase } 2 \text { Environmental Protection Agency } \\
\text { final rule standards } \\
\text { (Beginning January 1, 2000) }\end{array}$ \\
\hline Oxygen content & $2 \mathrm{wt}$ percent minimum \\
\hline Benzene content & 1 vol percent maximum \\
\hline Additives & No additives with heavy metals \\
\hline $\begin{array}{l}\text { Volatile Organic Compounds } \\
\text { (VOCs include all oxygenated and } \\
\text { non-oxygenated hydrocarbons } \\
\text { except methane and ethane) }\end{array}$ & $\begin{array}{l}\text { Must be reduced during summer by } 25.9 \\
\text { percent on a per-gallon basis or by } 27.4 \text { percent } \\
\text { on an averaged basis. }{ }^{\text {a }} \text { Greater reduction is } \\
\text { required in southern states. }\end{array}$ \\
\hline $\begin{array}{l}\text { Toxic Air Pollutants } \\
\text { (TAPs consist of benzene, } 1,3 \\
\text { butadiene, formaldehyde, } \\
\text { acetaldehyde, and polycyclic } \\
\text { organic matter) }\end{array}$ & $\begin{array}{l}\text { Must be reduced year-round by } 20 \text { percent on a } \\
\text { per-gallon basis or by } 21.5 \text { percent on an } \\
\text { averaged basis. }\end{array}$ \\
\hline Nitrogen Oxides (NOx) & $\begin{array}{l}\text { Must be reduced during summer by } 5.5 \\
\text { percent on a per-gallon basis or by } 6.8 \text { percent } \\
\text { on an averaged basis. If summer averaging is } \\
\text { used, then there must be at least a } 3 \text { percent } \\
\text { reduction on a per-gallon basis. Must not } \\
\text { increase during winter on a per-gallon basis and } \\
\text { must be reduced by } 1.5 \text { percent on an averaged } \\
\text { basis. }\end{array}$ \\
\hline \multicolumn{2}{|c|}{$\begin{array}{l}{ }^{\text {a}} \text { For the per-gallon standard, every batch of RFG produced at the refinery must meet the same } \\
\text { emissions-performance requirements. For the averaged standard, different batches may vary } \\
\text { within limits, as long as the refinery's total RFG output meets the specified average emissions } \\
\text { performance requirement. }\end{array}$} \\
\hline
\end{tabular}

\subsection{REPRESENTATION OF NON-LINEAR EMISSIONS MODELS IN A LINEAR PROGRAM}

The non-linear Complex Model presents difficult adaptation problems for use in refinery linear programs. Each gasoline blending component has VOC, TAP, and NOx blending values that vary with overall gasoline composition. The Complex Model is represented in ORNL-RYM by a linear delta method in which off-line software computes coefficients of change of emissions with changes in a gasoline property. These coefficients are then used in the off-line software to 
compute emissions blending values for the gasoline blending components. ORNL-RYM is solved iteratively, until convergence of the objective function value. 


\section{STUDY PREMISES}

There are three key premises for the ethanol demand study. First, it is assumed that gasoline blending is optimized, with minimum giveaway of gasoline quality. Modeled refineries can produce subgrade gasolines for shipment to blenders who add optimal volumes of ethanol to produce finished gasoline. Second, ethanol handling and logistics costs in refining/blending are assumed to be 5 cents per gallon. Third, it is assumed that consumers are indifferent to ethanol blends, neither seeking nor avoiding these gasolines (Anderson et al., 1988).

Technical premises for regional and seasonal product slates and revenues, raw materials and costs, and process capacity data for the ethanol demand study are shown in Tables 2 through 13. These modeling data are based on information sources discussed in the following paragraphs.

\subsection{REFINERY PRODUCTS}

Refinery net production rates from the Petroleum Supply Annual 1998 (U.S. DOE, 1999a) are projected by using the Reference Case growth rates published in the Annual Energy Outlook 1999 (U.S. DOE, 1999b).

Some gasolines are pooled by combining volumes and properties of regular, mid-grade, and premium grades. The source data for octane estimates and for pooling is the 1996 American Petroleum Institute/National Petroleum Refiners Association Survey of Refining Operations and Product Quality (API/NPRA, 1997) and the NPRA Survey of U.S. Gasoline Quality and U.S. Refining Industry Capacity to Produce Reformulated Gasolines (NPRA, 1991).

The production shares of RFG are based on monthly production shares reported in the Petroleum Supply Annual 1998 (U.S. DOE, 1999a).

Tables 14 and 15 summarize the specifications for gasoline emissions performance standards. To prevent air quality backsliding, RFG is limited to maximum emissions corresponding to the lessor of (1) federal statutory requirements for Phase 2 RFG or (2) emissions calculated from gasoline quality data in the 1996 American Petroleum Institute/National Petroleum Refiners Association Survey of Refining Operations and Product Quality (API/NPRA, 1997). To prevent air quality backsliding, $\mathrm{CG}$ is limited to maximum allowable emissions corresponding to the lessor of (1) Phase 2 RVP volatility control and antidumping or (2) emissions calculated from gasoline quality data in the 
Table 2. PADD I+III raw materials and products for year 2006 summer reference conditions

\begin{tabular}{|c|c|c|c|c|c|}
\hline \multicolumn{3}{|c|}{ Raw materials } & \multicolumn{3}{|l|}{ Products } \\
\hline CRUDE/RAW MATERIAL & \$/BARREL & MBD & PRODUCT & \$/BARREL & MBD \\
\hline & & & PROCESS GAS C2-FOE & 14.88 & \\
\hline ALGERIAN SAHARAN & 24.50 & 11.2 & STILL GAS TO PETROCHEM & 14.88 & \\
\hline KUWAIT & 20.01 & 273.1 & ETHANE FOE & 14.88 & \\
\hline SAUDI ARABIAN LIGHT & 20.73 & 1701.7 & ETHANE FOE & 14.88 & \\
\hline UAE & 20.44 & 1.3 & ETHYLENE FOE & 14.88 & \\
\hline GABON & 19.98 & 239.6 & PROPYLENE TO PETROCHEM & 19.25 & \\
\hline INDONESIA MINAS & 20.54 & 13.8 & PROPANE FUEL (LPG) & 15.87 & \\
\hline INDONESIA ATTIKA & 23.56 & 13.8 & PROPANE TO PETROCHEM & 15.87 & \\
\hline NIGERIAN MEDIUM & 19.38 & 690.8 & NORMAL BUTANE & 18.92 & \\
\hline VEN BOSCAN & 13.12 & 349.0 & SURPLUS NC4 & 18.92 & \\
\hline VEN BACH & 15.52 & 476.5 & N BUTYLENE & 19.54 & \\
\hline VEN TJ MED & 18.55 & 603.9 & ISO BUTANE & 21.10 & \\
\hline ANGOLAN & 20.27 & 441.8 & ISO BUTYLENE & 20.66 & \\
\hline ARGENTINA & 19.49 & 81.6 & ${ }^{*} \mathrm{C} 2-\mathrm{C} 4$ PRODUCTION SUMS TO 3 & $319.4 \mathrm{MBD}$ & \\
\hline CAMEROON & 19.98 & 1.2 & CG POOL (CG-M) & 28.71 & \\
\hline CANADIAN INTERMED & 20.16 & 147.4 & CG/ETOH POOL (CG-E) & 28.71 & \\
\hline CHINA BLEND & 19.77 & 23.1 & ${ }^{*}$ CG PRODUCTION SUMS TO 3770 & $0.2 \mathrm{MBD} \mathrm{EQ}$ & JIVALENT \\
\hline COLOMBIAN & 20.20 & 290.1 & & & \\
\hline CONGO & 19.38 & 77.4 & RFG REGULAR (RFG-M-R) & 28.74 & \\
\hline ECUADOR & 19.97 & 48.3 & RFG REMIUM (RFG-M-P) & 31.71 & \\
\hline GUATEMALA & 20.85 & 26.5 & RFG REGULAR/ETOH (RFG-E-R) & 28.74 & \\
\hline EGYPT & 15.83 & 13.2 & RFG REMIUM/ETOH (RFG-E-P) & 31.71 & \\
\hline MALAYSIA & 21.69 & 21.8 & ${ }^{*}$ RFG PRODUCTION SUMS TO 12 & $48.2 \mathrm{MBD}$ & \\
\hline MEXICAN ISTHMUS & 20.62 & 716.7 & EQUIVALENT & & \\
\hline MEXICAN MAYA & 16.66 & 716.7 & AVIATION GAS & 32.54 & 14.7 \\
\hline NORWAY & 21.88 & 239.5 & MIL JET FUEL JP8 & 25.37 & 82.5 \\
\hline RUSSIA & 20.44 & 9.7 & & & \\
\hline TRINIDAD SWEET & 20.85 & 30.9 & COMMERCIAL JET A & 25.32 & 1038.7 \\
\hline TRINIDAD SOUR & 18.55 & 30.9 & 2D ON-HIGHWAY DIESEL & 25.57 & 1168.6 \\
\hline UK & 21.88 & 156.5 & HEATING OIL (NO2) & 23.97 & 814.9 \\
\hline YEMEN & 21.92 & 5.2 & RESIDUAL $<.3 S$ & 19.7 & \\
\hline OHIO LIGHT & 24.93 & 7.4 & NET RESIDUAL $0.7-1.0 \%$ & 17.01 & \\
\hline ALABAMA LIGHT & 23.82 & 40.4 & *RESID PRODUCTION SUMS TO & $<168.4 \mathrm{MBD}$ & \\
\hline LOUISIANA COND & 28.91 & 86.7 & & & \\
\hline LOUISIANA NORTH & 23.82 & 50.0 & BUNKER & 14.32 & \\
\hline LOUISIANA HVY SWEET & 21.49 & 432.3 & NAPHTHA TO P. CHEM & 24.22 & \\
\hline MISSISSIPPI HEY & 22.95 & 14.8 & AROMATICS TO P. CHEM & 35.35 & \\
\hline MISSISSIPPI BAX & 18.78 & 31.2 & (BENZENE $=21 \mathrm{MBD} ;$ TOLUENE & /XYLENE $=$ & $71 \mathrm{MBD})$ \\
\hline NEW MEXICO INT & 23.77 & 18.7 & & & \\
\hline NEW MEXICO SOUR & 21.72 & 38.3 & GAS OIL TO PETROCHEM & 21.90 & \\
\hline TEXAS CONDENSATE & 25.39 & 53.9 & *PETROCHEM PRODUCTION SUMS & TO 306.8 & MBD \\
\hline TEXAS GULF REF & 23.34 & 381.1 & LUBES \& WAXES & 29.52 & 148.7 \\
\hline TEXAS EAST & 23.18 & 60.9 & & & \\
\hline TEXAS HAWKINS & 19.84 & 122.6 & COKE ST/CD LOW SULF & 42.08 & \\
\hline TEXAS WEST INTERMED & 23.77 & 344.4 & COKE ST/CD HIGH SULF & 24.36 & \\
\hline TEXAS WEST SOUR & 22.00 & 82.8 & COKE ST/CD XTRA HI SULF & 5.86 & \\
\hline OKLA CEMENT & 21.78 & 27.4 & ROAD OIL \& ASPHALT & 17.00 & $<283.0$ \\
\hline CALIFORNIA ELK HILLS & 22.42 & 53.3 & SULFUR & 51.09 & \\
\hline NATURAL GAS (FOE) & 17.73 & & & & \\
\hline NATURAL GASOLINE & 21.22 & $<73.3$ & & & \\
\hline ISOBUTANE & 21.20 & $<30.6$ & & & \\
\hline NORMAL BUTANE & 19.02 & $<17.8$ & & & \\
\hline ETHANOL & 33.53 & & & & \\
\hline METHANOL & 21.41 & & & & \\
\hline MTBE & 35.47 & & & & \\
\hline NAPHTHA/REF FEED & 24.32 & $<82.5$ & & & \\
\hline GAS OIL HI S & 22.00 & $<116.1$ & & & \\
\hline
\end{tabular}


Table 3. PADD I+III process capacity for year 2006 summer Reference conditions

\begin{tabular}{|c|c|}
\hline PROCESS & $\begin{array}{c}\text { CAPACITY } \\
\text { MBSD }\end{array}$ \\
\hline CRUDE DISTILLATION & 9611.8 \\
\hline VACUUM DISTILLATION & 4311.0 \\
\hline FLUID CAT CRACKER & 3843.6 \\
\hline FCC MEROX & $>0.0$ \\
\hline HYDROCRACKER-2 STAGE & 617.6 \\
\hline HYDROCRACKER-LOW CONVER & 23.0 \\
\hline RESID HYDROCRACKER & 213.9 \\
\hline COKER-DELAYED & 1117.7 \\
\hline VISBREAKER & 35.5 \\
\hline SOLVENT DEASPHALTING & 252.8 \\
\hline LUBE + WAX PLANTS & 176.8 \\
\hline NAPHTHA HYDROTREATER & 2514.0 \\
\hline DISTILLATE HDS & 2420.1 \\
\hline MID DIST DEEP HT & 401.8 \\
\hline FCC FEED HYDROF INER & 976.2 \\
\hline ATM RESID DESULF & 290.9 \\
\hline HP SEMI REGEN REFORMER & 717.2 \\
\hline LP CYCLIC REFORMER & 628.9 \\
\hline LP CONTINUOUS REFORMER & 885.0 \\
\hline ALKYLATION PLANT & 735.3 \\
\hline CAT POLYMERIZATION & 54.3 \\
\hline DIMERSOL & 4.0 \\
\hline BUTANE ISOMERIZATION & 98.8 \\
\hline PEN/HEX ISOMERIZATION & 464.2 \\
\hline AROMATICS RECOVERY (BTX) & 256.5 \\
\hline MTBE (ETHEROL) & 113.4 \\
\hline OCTGAIN & 0.0 \\
\hline GASOLINE SYNSAT & 0.0 \\
\hline CDTECH/FCC NAPHTHA DESUL & 1112.2 \\
\hline ALKY OF BENZENE & 0.0 \\
\hline REFORMATE SPLITTER & 839.5 \\
\hline NAPHTHA SPLITTER & 867.5 \\
\hline FCC GASOLINE SPLR & 855.5 \\
\hline HYDROGEN PLT, MBPD FOE & 80.0 \\
\hline SULFUR PLANT, MST/D & 18.8 \\
\hline
\end{tabular}


Table 4. PADD I+III raw materials and products for year 2006 summer with 3 percent maximum MTBE

\begin{tabular}{|c|c|c|c|c|c|}
\hline \multicolumn{3}{|c|}{ Raw materials } & \multicolumn{3}{|l|}{ Products } \\
\hline CRUDE/RAW MATERIAL & \$/BARREL & MBD & PRODUCT & \$/BARREL & MBD \\
\hline ALGERIAN SAHARAN & 24.50 & 11.3 & PROCESS GAS C2-FOE & 14.88 & \\
\hline KUWAIT & 20.01 & 276.0 & STILL GAS TO PETROCHEM & 14.88 & \\
\hline SAUDI ARABIAN LIGHT & 20.73 & 1719.5 & ETHANE FOE & 14.88 & \\
\hline UAE & 20.44 & 1.3 & ETHANE FOE & 14.88 & \\
\hline GABON & 19.98 & 242.2 & ETHYLENE FOE & 14.88 & \\
\hline INDONESIA MINAS & 20.54 & 13.9 & PROPYLENE TO PETROCHEM & 19.25 & \\
\hline INDONESIA ATTIKA & 23.56 & 13.9 & PROPANE FUEL (LPG) & 15.87 & \\
\hline NIGERIAN MEDIUM & 19.38 & 698.0 & PROPANE TO PETROCHEM & 15.87 & \\
\hline VEN BOSCAN & 13.12 & 352.7 & NORMAL BUTANE & 18.92 & \\
\hline VEN BACH & 15.52 & 481.4 & SURPLUS NC4 & 18.92 & \\
\hline VEN TJ MED & 18.55 & 610.2 & N BUTYLENE & 19.54 & \\
\hline ANGOLAN & 20.27 & 446.5 & ISO BUTANE & 21.10 & \\
\hline ARGENTINA & 19.49 & 82.5 & ISO BUTYLENE & 20.66 & \\
\hline CAMEROON & 19.98 & 1.2 & ${ }^{*} \mathrm{C} 2-\mathrm{C} 4$ PRODUCTION SUMS TO & $319.4 \mathrm{MBD}$ & \\
\hline CANADIAN INTERMED & 20.16 & 148.9 & CG POOL (CG-M) & 28.71 & \\
\hline CHINA BLEND & 19.77 & 23.3 & CG/ETOH POOL (CG-E) & 28.71 & \\
\hline COLOMBIAN & 20.20 & 293.2 & ${ }^{*}$ CG PRODUCTION SUMS TO 377 & $0.2 \mathrm{MBD} \mathrm{EQ}$ & UIVALENT \\
\hline CONGO & 19.38 & 78.2 & & & \\
\hline ECUADOR & 19.97 & 48.8 & RFG REGULAR (RFG-M-R) & 28.74 & \\
\hline GUATEMALA & 20.85 & 26.8 & RFG REMIUM (RFG-M-P) & 31.71 & \\
\hline EGYPT & 15.83 & 13.3 & RFG REGULAR/ETOH (RFG-E-R) & 28.74 & \\
\hline MALAYSIA & 21.69 & 22.0 & RFG REMIUM/ETOH (RFG-E-P) & 31.71 & \\
\hline MEXICAN ISTHMUS & 20.62 & 724.2 & ${ }^{*}$ RFG PRODUCTION SUMS TO 12 & $48.2 \mathrm{MBD}$ & \\
\hline MEXICAN MAYA & 16.66 & 724.2 & EQUIVALENT & & \\
\hline NORWAY & 21.88 & 242.0 & AVIATION GAS & 32.54 & 14.7 \\
\hline RUSSIA & 20.44 & 9.8 & MIL JET FUEL JP8 & 25.37 & 82.5 \\
\hline TRINIDAD SWEET & 20.85 & 31.3 & & & \\
\hline TRINIDAD SOUR & 18.55 & 31.3 & COMMERCIAL JET A & 25.32 & 1038.7 \\
\hline UK & 21.88 & 158.2 & 2D ON-HIGHWAY DIESEL & 25.57 & 1168.6 \\
\hline YEMEN & 21.92 & 5.2 & HEATING OIL (NO2) & 23.97 & 814.9 \\
\hline OHIO LIGHT & 24.93 & 7.5 & RESIDUAL $<.3 \mathrm{~S}$ & 19.7 & \\
\hline ALABAMA LIGHT & 23.82 & 40.8 & NET RESIDUAL $0.7-1.0 \div$ & 17.01 & \\
\hline LOUISIANA COND & 28.91 & 87.6 & *RESID PRODUCTION SUMS TO & $<168.4 \mathrm{MBD}$ & \\
\hline LOUISIANA NORTH & 23.82 & 50.5 & & & \\
\hline LOUISIANA HVY SWEET & 21.49 & 436.8 & BUNKER & 14.32 & \\
\hline MISSISSIPPI HEY & 22.95 & 15.0 & NAPHTHA TO P. CHEM & 24.22 & \\
\hline MISSISSIPPI BAX & 18.78 & 31.6 & AROMATICS TO P. CHEM & 35.35 & \\
\hline NEW MEXICO INT & 23.77 & 18.9 & (BENZENE $=21 \mathrm{MBD} ;$ TOLUENE & $/ \mathrm{XYLENE}=$ & $71 \mathrm{MBD})$ \\
\hline NEW MEXICO SOUR & 21.72 & 38.7 & GAS OIL TO PETROCHEM & 21.90 & \\
\hline TEXAS CONDENSATE & 25.39 & 54.4 & *PETROCHEM PRODUCTION SUMS & TO 306.8 & MBD \\
\hline TEXAS GULF REF & 23.34 & 385.1 & LUBES \& WAXES & 29.52 & 148.7 \\
\hline TEXAS EAST & 23.18 & 61.5 & & & \\
\hline TEXAS HAWKINS & 19.84 & 123.9 & COKE ST/CD LOW SULF & 42.08 & \\
\hline TEXAS WEST INTERMED & 23.77 & 348.0 & COKE ST/CD HIGH SULF & 24.36 & \\
\hline TEXAS WEST SOUR & 22.00 & 83.6 & COKE ST/CD XTRA HI SULF & 5.86 & \\
\hline OKLAHOMA CEMENT & 21.78 & 27.7 & ROAD OIL \& ASPHALT & 17.00 & $<283.0$ \\
\hline CALIFORNIA ELK HILLS & 22.42 & 53.8 & SULFUR & 51.09 & \\
\hline NATURAL GAS (FOE) & 17.73 & & & & \\
\hline NATURAL GASOLINE & 21.22 & $<73.3$ & & & \\
\hline ISOBUTANE & 21.20 & $<30.6$ & & & \\
\hline NORMAL BUTANE & 19.02 & $<17.8$ & & & \\
\hline ETHANOL & 33.53 & & & & \\
\hline METHANOL & 21.41 & & & & \\
\hline MTBE & 35.47 & & & & \\
\hline NAPHTHA/REF FEED & 24.32 & $<82.5$ & & & \\
\hline GAS OIL HI $S$ & 22.00 & $<116.1$ & & & \\
\hline
\end{tabular}


Table 5. PADD I+III process capacity for year 2006 summer with 3 percent maximum

\section{MTBE}

\begin{tabular}{|c|c|}
\hline PROCESS & $\begin{array}{c}\text { CAPACITY } \\
\text { MBSD }\end{array}$ \\
\hline CRUDE DISTILLATION & 9611.8 \\
\hline VACUUM DISTILLATION & 4311.0 \\
\hline FLUID CAT CRACKER & 3843.6 \\
\hline FCC MEROX & $>0.0$ \\
\hline HYDROCRACKER-2 STAGE & 617.6 \\
\hline HYDROCRACKER-LOW CONVER & 23.0 \\
\hline RESID HYDROCRACKER & 213.9 \\
\hline COKER-DELAYED & 1117.7 \\
\hline VISBREAKER & 35.5 \\
\hline SOLVENT DEASPHALTING & 252.8 \\
\hline LUBE + WAX PLANTS & 176.8 \\
\hline NAPHTHA HYDROTREATER & 2514.0 \\
\hline DISTILLATE HDS & 2420.1 \\
\hline MID DIST DEEP HT & 401.8 \\
\hline FCC FEED HYDROFINER & 976.2 \\
\hline ATM RESID DESULF & 290.9 \\
\hline HP SEMI REGEN REFORMER & 717.2 \\
\hline LP CYCLIC REFORMER & 628.9 \\
\hline LP CONTINUOUS REFORMER & 885.0 \\
\hline ALKYLATION PLANT & 735.3 \\
\hline CAT POLYMERIZATION & 54.3 \\
\hline DIMERSOL & 4.0 \\
\hline BUTANE ISOMERIZATION & 98.8 \\
\hline PEN/HEX ISOMERIZATION & 470.7 \\
\hline AROMATICS RECOVERY (BTX) & 256.5 \\
\hline MTBE (ETHEROL) & 113.4 \\
\hline OCTGAIN & 0.0 \\
\hline GASOLINE SYNSAT & 0.0 \\
\hline CDTECH/FCC NAPHTHA DESUL & 1112.2 \\
\hline ALKY OF BENZENE & 0.0 \\
\hline REFORMATE SPLITTER & 839.5 \\
\hline NAPHTHA SPLITTER & 867.5 \\
\hline FCC GASOLINE SPLR & 855.5 \\
\hline HYDROGEN PLT, MBPD FOE & 80.0 \\
\hline SULFUR PLANT, MST/D & 18.8 \\
\hline
\end{tabular}


Table 6. PADD I+III raw materials and products for year 2006 winter with 3 percent maximum MTBE

\begin{tabular}{|c|c|c|c|c|c|}
\hline \multicolumn{3}{|c|}{ Raw mat erials } & \multicolumn{3}{|c|}{ Prod uct s } \\
\hline CRUDE/RAW MATERIAL & \$/BARREL & MBD & PRODUCT & \$/BARREL & MBD \\
\hline ALGERIAN SAHARAN & 24.82 & 11.4 & PROCESS GAS C2-FOE & 15.99 & \\
\hline KUWAIT & 20.22 & 264.6 & STILL GAS TO PETROCHEM & 15.99 & \\
\hline SAUDI ARABIAN LIGHT & 20.95 & 1648.6 & ETHANE FOE & 15.99 & \\
\hline UAE & 20.66 & 1.2 & ETHANE FOE & 15.99 & \\
\hline GABON & 20.18 & 232.2 & ETHYLENE FOE & 15.99 & \\
\hline INDONESIA MINAS & 20.75 & 13.3 & PROPYLENE TO PETROCHEM & 20.68 & \\
\hline INDONESIA ATTIKA & 23.86 & 13.3 & PROPANE FUEL (LPG) & 17.05 & \\
\hline NIGERIAN MEDIUM & 19.56 & 669.2 & PROPANE TO PETROCHEM & 17.05 & \\
\hline VEN BOSCAN & 13.14 & 338.2 & NORMAL BUTANE & 20.33 & \\
\hline VEN BACH & 15.60 & 461.5 & SURPLUS NC4 & 20.33 & \\
\hline VEN TJ MED & 18.71 & 585.0 & N BUTYLENE & 20.99 & \\
\hline ANGOLAN & 20.48 & 428.1 & ISO BUTANE & 22.67 & \\
\hline ARGENTINA & 19.68 & 79.1 & ISO BUTYLENE & 22.20 & \\
\hline CAMEROON & 20.18 & 1.2 & CG POOL (CG-M) & 26.96 & \\
\hline CANADIAN INTERMED & 20.37 & 142.8 & CG/ETOH POOL (CG-E) & 26.96 & \\
\hline CHINA BLEND & 19.96 & 22.3 & *CG PRODUCTION SUMS TO 3535 & $5.2 \mathrm{MBD} \mathrm{EQ}$ & QUIVALENT \\
\hline COLOMBIAN & 20.41 & 281.1 & & & \\
\hline CONGO & 19.56 & 75.0 & RFG REGULAR (RFG-M-R) & 27.60 & \\
\hline ECUADOR & 20.17 & 46.8 & RFG REMIUM (RFG-M-P) & 32.03 & \\
\hline GUATEMALA & 21.07 & 25.7 & RFG REGULAR/ETOH (RFG-E-R) & 27.60 & \\
\hline EGYPT & 15.92 & 12.8 & RFG REMIUM/ETOH (RFG-E-P) & 32.03 & \\
\hline MALAYSIA & 21.94 & 21.1 & *RFG PRODUCTION SUMS TO 131 & $13.7 \mathrm{MBD}$ & \\
\hline MEXICAN ISTHMUS & 20.84 & 694.3 & EQUIVALENT & & \\
\hline MEXICAN MAYA & 16.77 & 694.3 & AVIATION GAS & 32.86 & 13.6 \\
\hline NORWAY & 22.13 & 232.0 & MIL JET FUEL JP8 & 24.85 & 80.4 \\
\hline RUSSIA & 20.65 & 9.4 & & & \\
\hline TRINIDAD SWEET & 21.07 & 30.0 & COMMERCIAL JET A & 24.80 & 1083.3 \\
\hline TRINIDAD SOUR & 18.71 & 30.0 & 2D ON-HIGHWAY DIESEL & 25.04 & 1169.4 \\
\hline UK & 22.13 & 151.7 & HEATING OIL (NO2) & 24.94 & 815.2 \\
\hline YEMEN & 22.17 & 5.0 & RESIDUAL $<.3 S$ & 19.65 & \\
\hline OHIO LIGHT & 25.32 & 7.2 & NET RESIDUAL $0.7-1.0 \%$ & 16.96 & \\
\hline ALABAMA LIGHT & 24.21 & 39.1 & BUNKER & 14.90 & \\
\hline LOUISIANA COND & 29.30 & 84.0 & NAPHTHA TO P. CHEM & 22.47 & \\
\hline LOUISIANA NORTH & 24.21 & 48.4 & AROMATICS TO P. CHEM & 33.60 & \\
\hline LOUISIANA HVY SWEET & 21.88 & 418.8 & (BENZENE < $41.9 \mathrm{MBD}$ & & \\
\hline MISSISSIPPI HEY & 23.34 & 14.4 & TOLUENE/XYLENE $=71$ TO 129. & $5 \mathrm{MBD})$ & \\
\hline MISSISSIPPI BAX & 19.16 & 30.3 & GAS OIL TO PETROCHEM & 22.87 & \\
\hline NEW MEXICO INT & 24.15 & 18.1 & *PETROCHEM PRODUCTION SUMS & TO 300.8 & MBD \\
\hline NEW MEXICO SOUR & 22.10 & 37.1 & LUBES \& WAXES & 29.85 & 149.0 \\
\hline TEXAS CONDENSATE & 25.78 & 52.2 & & & \\
\hline TEXAS GULF REF & 23.73 & 369.2 & COKE ST/CD LOW SULF & 42.54 & \\
\hline TEXAS EAST & 23.56 & 59.0 & COKE ST/CD HIGH SULF & 24.63 & \\
\hline TEXAS HAWKINS & 20.23 & 118.8 & COKE ST/CD XTRA HI SULF & 5.92 & \\
\hline TEXAS WEST INTERMED & 24.15 & 333.6 & ROAD OIL \& ASPHALT & 17.19 & $<191.1$ \\
\hline TEXAS WEST SOUR & 22.38 & 80.2 & SULFUR & 53.67 & \\
\hline OKLAHOMA CEMENT & 22.17 & 26.6 & & & \\
\hline CALIFORNIA ELK HILLS & 22.80 & 51.6 & & & \\
\hline NATURAL GAS (FOE) & 17.93 & & & & \\
\hline NATURAL GASOLINE & 19.47 & $<70.8$ & & & \\
\hline ISOBUTANE & 22.77 & $<30.6$ & & & \\
\hline NORMAL BUTANE & 20.43 & $<95.6$ & & & \\
\hline ETHANOL & 47.24 & & & & \\
\hline METHANOL & 19.66 & & & & \\
\hline MTBE & 33.72 & & & & \\
\hline NAPHTHA/REF FEED & 22.57 & $<82.5$ & & & \\
\hline GAS OIL HI S & 22.97 & $<116.1$ & & & \\
\hline
\end{tabular}


Table 7. PADD I+III process capacity for year 2006 winter with 3 percent maximum MTBE

(with summer investment capacity added)

\begin{tabular}{|c|c|}
\hline PROCESS & $\begin{array}{c}\text { CAPACITY } \\
\text { MBSD }\end{array}$ \\
\hline CRUDE DISTILLATION & 9687.1 \\
\hline VACUUM DISTILLATION & 4311.0 \\
\hline FLUID CAT CRACKER & 4049.0 \\
\hline FCC MEROX & $>0.0$ \\
\hline HYDROCRACKER-2 STAGE & 617.6 \\
\hline HYDROCRACKER-LOW CONVER & 23.0 \\
\hline RESID HYDROCRACKER & 249.5 \\
\hline COKER-DELAYED & 1117.7 \\
\hline VISBREAKER & 35.5 \\
\hline SOLVENT DEASPHALTING & 252.8 \\
\hline LUBE + WAX PLANTS & 176.8 \\
\hline NAPHTHA HYDROTREATER & 2571.3 \\
\hline DISTILLATE HDS & 2420.1 \\
\hline MID DIST DEEP HT & 401.8 \\
\hline FCC FEED HYDROFINER & 976.2 \\
\hline ATM RESID DESULF & 290.9 \\
\hline HP SEMI REGEN REFORMER & 717.2 \\
\hline LP CYCLIC REFORMER & 628.9 \\
\hline LP CONTINUOUS REFORMER & 959.8 \\
\hline ALKYLATION PLANT & 764.8 \\
\hline CAT POLYMERIZATION & 54.4 \\
\hline DIMERSOL & 4.0 \\
\hline BUTANE ISOMERIZATION & 98.8 \\
\hline PEN/HEX ISOMERIZATION & 499.9 \\
\hline AROMATICS RECOVERY (BTX) & 256.5 \\
\hline MTBE (ETHEROL) & 113.4 \\
\hline OCTGAIN & 0.0 \\
\hline GASOLINE SYNSAT & 0.0 \\
\hline CDTECH/FCC NAPHTHA DESUL & 1183.0 \\
\hline ALKY OF BENZENE & 0.0 \\
\hline REFORMATE SPLITTER & 839.5 \\
\hline NAPHTHA SPLITTER & 867.5 \\
\hline FCC GASOLINE SPLR & 855.5 \\
\hline HYDROGEN PLT, MBPD FOE & 80.0 \\
\hline SULFUR PLANT, MST/D & 19.3 \\
\hline
\end{tabular}


Table 8. PADD II raw materials and products for year 2006 summer Reference conditions

\begin{tabular}{|c|c|c|c|c|c|}
\hline \multicolumn{3}{|c|}{ Raw materials } & \multicolumn{3}{|l|}{ Products } \\
\hline CRUDE/RAW MATERIAL & \$/BARREL & MBD & PRODUCT & \$/BARREL & MBD \\
\hline & & & PROCESS GAS C2-FOE & 15.54 & \\
\hline KUWAIT & 20.01 & 35.1 & STILL GAS TO PETROCHEM & 15.54 & \\
\hline SAUDI ARABIAN HEAVY & 18.88 & 3.8 & ETHANE FOE & 15.54 & \\
\hline SAUDI ARABIAN MEDIUM & 19.79 & 1.9 & ETHANE FOE & 15.54 & \\
\hline SAUDI ARABIAN LIGHT & 20.73 & 206.2 & ETHYLENE FOE & 15.54 & \\
\hline SAUDI BERRI & 22.66 & 15.0 & PROPYLENE TO PETROCHEM & 20.10 & \\
\hline IRAQ & 20.86 & 37.1 & PROPANE FUEL (LPG) & 16.57 & \\
\hline UAE & 20.44 & 1.7 & PROPANE TO PETROCHEM & 16.57 & \\
\hline GABON & 19.98 & 1.1 & NORMAL BUTANE & 19.75 & \\
\hline INDONESIA MINAS & 20.54 & 3.0 & SURPLUS NC4 & 19.75 & \\
\hline INDONESIA ATTIKA & 23.56 & 2.8 & N BUTYLENE & 20.40 & \\
\hline NIGERIAN FORCADOS & 20.45 & 22.2 & ISO BUTANE & 22.03 & \\
\hline NIGERIAN MEDIUM & 19.38 & 79.5 & ISO BUTYLENE & 21.57 & \\
\hline NIGERIAN LIGHT & 23.97 & 15.4 & CG POOL (CG-M) & 29.77 & \\
\hline VEN BOSCAN & 13.12 & 87.4 & CG/ETOH POOL (CG-E) 2 & 29.77 & \\
\hline VEN BACH & 15.52 & 74.9 & *CG PRODUCTION SUMS TO 1697. & $.0 \mathrm{MBD}$ EQUI & IVALENT \\
\hline VEN TJ MED & 18.55 & 0.4 & & & \\
\hline ANGOLAN & 20.27 & 104.9 & RFG REGULAR (RFG-M-R) & 29.80 & \\
\hline ARGENTINA & 19.49 & 0.8 & RFG REMIUM (RFG-M-P) & 32.77 & \\
\hline CANADIAN HVY & 17.10 & 381.3 & RFG REGULAR/ETOH (RFG-E-R) 2 & 29.80 & \\
\hline CANADIAN LLOYD & 18.72 & 373.7 & RFG REMIUM/ETOH (RFG-E-P) 3 & 32.77 & \\
\hline CANADIAN INTERPR & 20.72 & 150.0 & 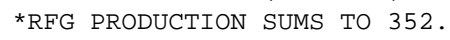 & $.9 \mathrm{MBD} E Q U I$ & IVALENT \\
\hline CANADIAN FED & 23.19 & 78.8 & & & \\
\hline CANADIAN RANGLD & 23.12 & 142.4 & AVIATION GAS & 33.60 & 4.9 \\
\hline COLOMBIAN & 20.20 & 123.9 & MIL JET FUEL JP8 & 26.48 & 14.0 \\
\hline CONGO & 19.38 & 5.0 & & & \\
\hline ECUADOR & 19.97 & 2.5 & COMMERCIAL JET A & 26.43 & 262.2 \\
\hline MALAYSIA & 21.69 & 0.4 & 2D ON-HIGHWAY DIESEL & 26.63 & 657.3 \\
\hline MEXICAN ISTHMUS & 20.62 & 35.4 & HEATING OIL (NO2) & 25.03 & 262.9 \\
\hline MEXICAN MAYA & 16.66 & 45.0 & & & \\
\hline NORWAY & 21.88 & 19.3 & RESIDUAL $<.3 .3$ & 20.45 & \\
\hline UK & 21.88 & 31.0 & NET RESIDUAL $0.7-1.0 \div$ & 17.76 & \\
\hline ALABAMA HEAVY & 19.97 & 7.0 & ${ }^{*}$ RESID PRODUCTION SUMS TO $<6$ & $68.2 \mathrm{MBD}$ & \\
\hline ALASKA NORTH SLOPE & 19.72 & 3.9 & $\begin{array}{ll}\text { BUNKER } & 1\end{array}$ & 15.07 & \\
\hline LOUISIANA LIGHT & 22.63 & 139.3 & NAPHTHA TO P. CHEM & 25.28 & \\
\hline LOUISIANA HVY SWEET & 21.49 & 111.4 & AROMATICS TO P. CHEM 3 & 36.41 & \\
\hline MISSISSIPPI HEY & 22.95 & 40.1 & (BENZENE <2.3 MBD; TOLUENE/X & XYLENE $<15$. & $.8 \mathrm{MBD})$ \\
\hline ILLINOIS SWEET & 24.03 & 29.3 & & & \\
\hline INDIANA SWEET & 23.34 & 4.7 & GAS OIL TO PETROCHEM & 22.96 & \\
\hline KANSAS SWEET & 24.25 & 79.5 & *PETROCHEM PRODUCTION SUMS T & TO $<68.1 \mathrm{MB}$ & BD \\
\hline KENTUCKY SWEET & 23.34 & 8.9 & LUBES \& WAXES 3 & 30.82 & 28.6 \\
\hline MICHIGAN SWEET & 24.03 & 30.9 & & & \\
\hline OKLAHOMA CEMET & 21.78 & 56.2 & COKE ST/CD LOW SULF & 43.94 & \\
\hline OKLAHOMA COND & 26.00 & 6.3 & COKE ST/CD HIGH SULF & 25.43 & \\
\hline OKLAHOMA GARBER & 24.25 & 65.9 & COKE ST/CD XTRA HI SULF & 6.12 & \\
\hline SOUTH DAKOTA SWEET & 22.92 & 3.1 & ROAD OIL \& ASPHALT & 17.75 & $<215.9$ \\
\hline NEW MEXICO INTER & 23.77 & 158.8 & SULFUR & 53.34 & \\
\hline COLORADO RANGLEY & 22.84 & 1.1 & & & \\
\hline MONTANA SOUR & 19.29 & 0.2 & & & \\
\hline WYOMING SOUR & 19.29 & 16.5 & & & \\
\hline WYOMING SWEET & 22.92 & 14.7 & & & \\
\hline TEXAS EAST & 23.18 & 139.3 & & & \\
\hline TEXAS SCURRY & 23.60 & 52.9 & & & \\
\hline TEXAS WEST INTERMEDIATE & 23.77 & 172.7 & & & \\
\hline TEXAS SOUR & 22.00 & 463.9 & & & \\
\hline
\end{tabular}


Table 8 (Continued). PADD II raw materials and products for year 2006 summer Reference conditions

\begin{tabular}{|c|c|c|c|c|c|}
\hline \multicolumn{3}{|c|}{ Raw materials } & \multicolumn{3}{|c|}{ Products } \\
\hline CRUDE/RAW MATERIAL & \$/BARREL & MBD & PRODUCT & \$/BARREL & MBD \\
\hline NATURAL GAS (FOE) & 18.51 & & & & \\
\hline NATURAL GASOLINE & 22.28 & $<39.3$ & & & \\
\hline ISOBUTANE & 22.13 & $<46.1$ & & & \\
\hline NORMAL BUTANE & 19.85 & $<32.2$ & & & \\
\hline ETHANOL & 30.10 & & & & \\
\hline METHANOL & 22.49 & & & & \\
\hline MTBE & 36.53 & & & & \\
\hline NAPHTHA/REF FEED & 25.38 & $<27.2$ & & & \\
\hline GAS OIL MED $S$ & 23.06 & $<29.8$ & & & \\
\hline GASOLINE BLEND STOCKS & 37.72 & $<17.6$ & & & \\
\hline
\end{tabular}

Table 9. PADD II process capacity for year 2006 summer Reference conditions

\begin{tabular}{|c|c|}
\hline PROCESS & $\begin{array}{c}\text { CAPACITY } \\
\text { MBSD }\end{array}$ \\
\hline CRUDE DISTILLATION & 4008.5 \\
\hline VACUUM DISTILLATION & 1491.4 \\
\hline FLUID CAT CRACKER & 1555.9 \\
\hline MEROX & $>0.0$ \\
\hline HYDROCRACKER-2 STAGE & 325.4 \\
\hline HYDROCRACKER-LOW CONVER & 12.5 \\
\hline COKER-DELAYED & 421.2 \\
\hline SOLVENT DEASPHALTING & 37.4 \\
\hline LUBE + WAX PLANTS & 34.5 \\
\hline NAPHTHA HYDROTREATER & 1319.0 \\
\hline DISTILLATE HDS & 764.6 \\
\hline MID DIST DEEP HT & 326.0 \\
\hline FCC FEED HYDROFINER & 540.0 \\
\hline ATM RESID DESULF & 66.8 \\
\hline HP SEMI REGEN REFORMER & 279.3 \\
\hline LP CYCLIC REFORMER & 155.3 \\
\hline LP CONTINUOUS REFORMER & 629.8 \\
\hline ALKYLATION PLANT & 351.5 \\
\hline CAT POLYMERIZATION & 13.6 \\
\hline DIMERSOL & 5.2 \\
\hline BUTANE ISOMERIZATION & 22.7 \\
\hline PEN/HEX ISOMERIZATION & 258.5 \\
\hline AROMATICS RECOVERY (BTX) & 51.2 \\
\hline MTBE (ETHEROL) & 13.8 \\
\hline OCTGAIN & 0.0 \\
\hline GASOLINE SYNSAT & 0.0 \\
\hline CDTECH/FCC NAPHTHA DESUL & 442.8 \\
\hline ALKY OF BENZENE & 0.0 \\
\hline REFORMATE SPLITTER & 297.9 \\
\hline NAPHTHA SPLITTER & 173.0 \\
\hline FCC GASOLINE SPLR & 175.3 \\
\hline HYDROGEN PLT, MBPD FOE & 23.2 \\
\hline SULFUR PLANT,MST/D & 6.6 \\
\hline
\end{tabular}


Table 10. PADD II raw materials and products for year 2006 summer MTBE ban

\begin{tabular}{|c|c|c|c|c|c|}
\hline \multicolumn{3}{|c|}{ Raw materials } & \multicolumn{3}{|l|}{ Products } \\
\hline CRUDE/RAW MATERIAL & \$/BARREL & MBD & PRODUCT & \$/BARREL & MBD \\
\hline & & & PROCESS GAS C2-FOE & 15.54 & \\
\hline KUWAIT & 20.01 & 35.2 & STILL GAS TO PETROCHEM & 15.54 & \\
\hline SAUDI ARABIAN HEAVY & 18.88 & 3.8 & ETHANE FOE & 15.54 & \\
\hline SAUDI ARABIAN MEDIUM & 19.79 & 1.9 & ETHANE FOE & 15.54 & \\
\hline SAUDI ARABIAN LIGHT & 20.73 & 206.7 & ETHYLENE FOE & 15.54 & \\
\hline SAUDI BERRI & 22.66 & 15.0 & PROPYLENE TO PETROCHEM & 20.10 & \\
\hline IRAQ & 20.86 & 37.2 & PROPANE FUEL (LPG) & 16.57 & \\
\hline $\mathrm{UAE}$ & 20.44 & 1.7 & PROPANE TO PETROCHEM & 16.57 & \\
\hline GABON & 19.98 & 1.1 & NORMAL BUTANE & 19.75 & \\
\hline INDONESIA MINAS & 20.54 & 3.0 & SURPLUS NC4 & 19.75 & \\
\hline INDONESIA ATTIKA & 23.56 & 2.8 & N BUTYLENE & 20.40 & \\
\hline NIGERIAN FORCADOS & 20.45 & 22.3 & ISO BUTANE & 22.03 & \\
\hline NIGERIAN MEDIUM & 19.38 & 79.7 & ISO BUTYLENE & 21.57 & \\
\hline NIGERIAN LIGHT & 23.97 & 15.4 & CG POOL (CG-M) & 29.77 & \\
\hline VEN BOSCAN & 13.12 & 87.6 & CG/ETOH POOL (CG-E) & 29.77 & \\
\hline VEN BACH & 15.52 & 75.1 & *CG PRODUCTION SUMS TO 1697 & $.0 \mathrm{MBD}$ EQUI & IVALENT \\
\hline VEN TJ MED & 18.55 & 0.4 & & & \\
\hline ANGOLAN & 20.27 & 105.1 & RFG REGULAR (RFG-M-R) & 29.80 & \\
\hline ARGENTINA & 19.49 & 0.8 & RFG REMIUM (RFG-M-P) & 32.77 & \\
\hline CANADIAN HVY & 17.10 & 382.3 & RFG REGULAR/ETOH (RFG-E-R) & 29.80 & \\
\hline CANADIAN LLOYD & 18.72 & 374.6 & RFG REMIUM/ETOH (RFG-E-P) & 32.77 & \\
\hline CANADIAN INTERPR & 20.72 & 150.4 & 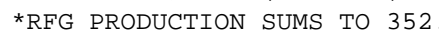 & $.9 \mathrm{MBD}$ EQUI & IVALENT \\
\hline CANADIAN FED & 23.19 & 79.0 & & & \\
\hline CANADIAN RANGLD & 23.12 & 142.7 & AVIATION GAS & 33.60 & 4.9 \\
\hline COLOMBIAN & 20.20 & 124.2 & MIL JET FUEL JP8 & 26.48 & 14.0 \\
\hline CONGO & 19.38 & 5.0 & & & \\
\hline ECUADOR & 19.97 & 2.5 & COMMERCIAL JET A & 26.43 & 262.2 \\
\hline MALAYSIA & 21.69 & 0.4 & 2D ON-HIGHWAY DIESEL & 26.63 & 657.3 \\
\hline MEXICAN ISTHMUS & 20.62 & 35.5 & HEATING OIL (NO2) & 25.03 & 262.9 \\
\hline MEXICAN MAYA & 16.66 & 45.1 & & & \\
\hline NORWAY & 21.88 & 19.3 & RESIDUAL $<.3 \mathrm{~S}$ & 20.45 & \\
\hline UK & 21.88 & 31.1 & NET RESIDUAL $0.7-1.0 \div$ & 17.76 & \\
\hline ALABAMA HEAVY & 19.97 & 7.0 & ${ }^{*}$ RESID PRODUCTION SUMS TO < & $68.2 \mathrm{MBD}$ & \\
\hline ALASKA NORTH SLOPE & 19.72 & 3.9 & BUNKER & 15.07 & \\
\hline LOUISIANA LIGHT & 22.63 & 139.6 & NAPHTHA TO P. CHEM & 25.28 & \\
\hline LOUISIANA HVY SWEET & 21.49 & 111.7 & AROMATICS TO P. CHEM & 36.41 & \\
\hline MISSISSIPPI HEY & 22.95 & 40.2 & (BENZENE <2.3 MBD; TOLUENE/ & XYLENE $<15$. & $.8 \mathrm{MBD})$ \\
\hline ILLINOIS SWEET & 24.03 & 29.4 & & & \\
\hline INDIANA SWEET & 23.34 & 4.7 & GAS OIL TO PETROCHEM & 22.96 & \\
\hline KANSAS SWEET & 24.25 & 79.7 & *PETROCHEM PRODUCTION SUMS & $\mathrm{TO}<68.1 \mathrm{MB}$ & BD \\
\hline KENTUCKY SWEET & 23.34 & 8.9 & LUBES \& WAXES & 30.82 & 28.6 \\
\hline MICHIGAN SWEET & 24.03 & 30.9 & & & \\
\hline OKLAHOMA CEMET & 21.78 & 56.4 & COKE ST/CD LOW SULF & 43.94 & \\
\hline OKLAHOMA COND & 26.00 & 6.3 & COKE ST/CD HIGH SULF & 25.43 & \\
\hline OKLAHOMA GARBER & 24.25 & 66.1 & COKE ST/CD XTRA HI SULF & 6.12 & \\
\hline SOUTH DAKOTA SWEET & 22.92 & 3.1 & ROAD OIL \& ASPHALT & 17.75 & $<215.9$ \\
\hline NEW MEXICO INTER & 23.77 & 159.2 & SULFUR & 53.34 & \\
\hline COLORADO RANGLEY & 22.84 & 1.2 & & & \\
\hline MONTANA SOUR & 19.29 & 0.2 & & & \\
\hline WYOMING SOUR & 19.29 & 16.5 & & & \\
\hline WYOMING SWEET & 22.92 & 14.7 & & & \\
\hline TEXAS EAST & 23.18 & 139.6 & & & \\
\hline TEXAS SCURRY & 23.60 & 53.1 & & & \\
\hline TEXAS WEST INTERMEDIATE & 23.77 & 173.2 & & & \\
\hline TEXAS SOUR & 22.00 & 465.0 & & & \\
\hline
\end{tabular}


Table 10 (Continued). PADD II raw materials and products for year 2006 summer MTBE ban

\begin{tabular}{|c|c|c|c|c|c|}
\hline \multicolumn{3}{|c|}{ Raw materials } & \multicolumn{3}{|c|}{ Products } \\
\hline CRUDE/RAW MATERIAL & \$/BARREL & MBD & PRODUCT & \$/BARREL & MBD \\
\hline NATURAL GAS (FOE) & 18.51 & & & & \\
\hline NATURAL GASOLINE & 22.28 & $<39.3$ & & & \\
\hline ISOBUTANE & 22.13 & $<46.1$ & & & \\
\hline NORMAL BUTANE & 19.85 & $<32.2$ & & & \\
\hline ETHANOL & 33.99 & & & & \\
\hline NAPHTHA/REF FEED & 25.38 & $<27.2$ & & & \\
\hline GAS OIL MED $S$ & 23.06 & $<29.8$ & & & \\
\hline GASOLINE BLEND STOCKS & 37.72 & $<17.6$ & & & \\
\hline
\end{tabular}

Table 11. PADD II process capacity for year 2006 summer MTBE ban

\begin{tabular}{|c|c|}
\hline PROCESS & $\begin{array}{l}\text { CAPACITY } \\
\text { MBSD }\end{array}$ \\
\hline CRUDE DISTILLATION & 4008.5 \\
\hline VACUUM DISTILLATION & 1491.4 \\
\hline FLUID CAT CRACKER & 1555.9 \\
\hline MEROX & $>0.0$ \\
\hline HYDROCRACKER-2 STAGE & 325.4 \\
\hline HYDROCRACKER-LOW CONVER & 12.5 \\
\hline COKER-DELAYED & 427.6 \\
\hline SOLVENT DEASPHALTING & 37.4 \\
\hline LUBE + WAX PLANTS & 34.5 \\
\hline NAPHTHA HYDROTREATER & 1319.0 \\
\hline DISTILLATE HDS & 764.6 \\
\hline MID DIST DEEP HT & 326.0 \\
\hline FCC FEED HYDROFINER & 540.0 \\
\hline ATM RESID DESULF & 66.8 \\
\hline HP SEMI REGEN REFORMER & 279.3 \\
\hline LP CYCLIC REFORMER & 155.3 \\
\hline LP CONTINUOUS REFORMER & 629.8 \\
\hline ALKYLATION PLANT & 351.5 \\
\hline CAT POLYMERIZATION & 13.6 \\
\hline DIMERSOL & 5.2 \\
\hline BUTANE ISOMERIZATION & 22.7 \\
\hline PEN/HEX ISOMERIZATION & 258.5 \\
\hline AROMATICS RECOVERY (BTX) & 51.2 \\
\hline MTBE (ETHEROL) & 13.8 \\
\hline OCTGAIN & 0.0 \\
\hline GASOLINE SYNSAT & 0.0 \\
\hline CDTECH/FCC NAPHTHA DESUI & 442.8 \\
\hline ALKY OF BENZENE & 0.0 \\
\hline REFORMATE SPLITTER & 297.9 \\
\hline NAPHTHA SPLITTER & 173.0 \\
\hline FCC GASOLINE SPLR & 284.6 \\
\hline HYDROGEN PLT, MBPD FOE & 27.8 \\
\hline SULFUR PLANT, MST/D & 6.6 \\
\hline
\end{tabular}


Table 12. PADD II raw materials and products for year 2006 winter MTBE ban

\begin{tabular}{|c|c|c|c|c|c|}
\hline \multicolumn{3}{|c|}{ Raw materials ${ }^{a}$} & \multicolumn{3}{|l|}{ Products } \\
\hline CRUDE/RAW MATERIAL & \$/BARREL & MBD & PRODUCT & \$/BARREL & MBD \\
\hline ALGERIAN SAHARAN & 24.50 & 4.4 & PROCESS GAS C2-FOE & 15.73 & \\
\hline KUWAIT & 20.01 & 106.4 & STILL GAS TO PETROCHEM & 15.73 & \\
\hline SAUDI ARABIAN LIGHT & 20.73 & 662.8 & ETHANE FOE & 15.73 & \\
\hline $\mathrm{UAE}$ & 20.44 & 0.5 & ETHANE FOE & 15.73 & \\
\hline GABON & 19.98 & 93.3 & ETHYLENE FOE & 15.73 & \\
\hline INDONESIA MINAS & 20.54 & 5.4 & PROPYLENE TO PETROCHEM & 20.35 & \\
\hline INDONESIA ATTIKA & 23.56 & 5.4 & PROPANE FUEL (LPG) & 16.78 & \\
\hline NIGERIAN MEDIUM & 19.38 & 269.0 & PROPANE TO PETROCHEM & 16.78 & \\
\hline VEN BOSCAN & 13.12 & 135.9 & NORMAL BUTANE & 20.00 & \\
\hline VEN BACH & 15.52 & 185.6 & SURPLUS NC4 & 20.00 & \\
\hline VEN TJ MED & 18.55 & 235.2 & N BUTYLENE & 20.65 & \\
\hline ANGOLAN & 20.27 & 172.1 & ISO BUTANE & 22.30 & \\
\hline ARGENTINA & 19.49 & 31.8 & ISO BUTYLENE & 21.84 & \\
\hline CAMEROON & 19.98 & 0.5 & CG POOL (CG-M) & 27.18 & \\
\hline CANADIAN INTERMED & 20.16 & 57.4 & CG/ETOH POOL (CG-E) & 27.18 & \\
\hline CHINA BLEND & 19.77 & 9.0 & ${ }^{*}$ CG PRODUCTION SUMS TO 1753. & $3.0 \mathrm{MBD} E Q U I$ & IVALENT \\
\hline COLOMBIAN & 20.20 & 113.0 & & & \\
\hline CONGO & 19.38 & 30.1 & RFG REGULAR (RFG-M-R) & 28.07 & \\
\hline ECUADOR & 19.97 & 18.8 & RFG REMIUM (RFG-M-P) & 29.75 & \\
\hline GUATEMALA & 20.85 & 10.3 & RFG REGULAR/ETOH (RFG-E-R) 2 & 28.07 & \\
\hline EGYPT & 15.83 & 5.1 & RFG REMIUM/ETOH (RFG-E-P) & 29.75 & \\
\hline MALAYSIA & 21.69 & 8.5 & ${ }^{*}$ RFG PRODUCTION SUMS TO 330. & $.5 \mathrm{MBD} E Q U I$ & IVALENT \\
\hline MEXICAN ISTHMUS & 20.62 & 279.1 & & & \\
\hline MEXICAN MAYA & 16.66 & 279.1 & AVIATION GAS & 33.91 & 4.7 \\
\hline NORWAY & 21.88 & 93.3 & MIL JET FUEL JP 8 & 26.79 & 13.7 \\
\hline RUSSIA & 20.44 & 3.8 & & & \\
\hline TRINIDAD SWEET & 20.85 & 12.0 & COMMERCIAL JET A & 26.74 & 283.9 \\
\hline TRINIDAD SOUR & 18.55 & 12.0 & 2D ON-HIGHWAY DIESEL & 26.94 & 637.4 \\
\hline UK & 21.88 & 61.0 & HEATING OIL (NO2) & 25.34 & 255.0 \\
\hline YEMEN & 21.92 & 2.0 & & & \\
\hline OHIO LIGHT & 24.93 & 2.9 & RESIDUAL $<.3$. & 20.71 & \\
\hline ALABAMA LIGHT & 23.82 & 15.7 & NET RESIDUAL $0.7-1.0 \%$ & 17.98 & \\
\hline LOUISIANA COND & 28.91 & 33.8 & BUNKER & 15.26 & \\
\hline LOUISIANA NORTH & 23.82 & 19.5 & NAPHTHA TO P. CHEM & 22.69 & \\
\hline LOUISIANA HVY SWEET & 21.49 & 168.4 & AROMATICS TO P. CHEM & 33.82 & \\
\hline MISSISSIPPI HEY & 22.95 & 5.8 & (BENZENE $<2.3 \mathrm{MBD} ;$ TOLUENE/X & XYLENE $<15$. & $.8 \mathrm{MBD})$ \\
\hline MISSISSIPPI BAX & 18.78 & 12.2 & & & \\
\hline NEW MEXICO INT & 23.77 & 7.3 & GAS OIL TO PETROCHEM & 23.27 & \\
\hline NEW MEXICO SOUR & 21.72 & 14.9 & *PETROCHEM PRODUCTION SUMS T & $\mathrm{TO}<48.4 \mathrm{MB}$ & IBD \\
\hline TEXAS CONDENSATE & 25.39 & 21.0 & LUBES \& WAXES 3 & 31.20 & 28.0 \\
\hline TEXAS GULF REF & 23.34 & 148.4 & & & \\
\hline TEXAS EAST & 23.18 & 61.5 & COKE ST/CD LOW SULF & 44.49 & \\
\hline TEXAS HAWKINS & 19.84 & 123.9 & COKE ST/CD HIGH SULF & 25.75 & \\
\hline TEXAS WEST INTERMED & 23.77 & 134.1 & COKE ST/CD XTRA HI SULF & 6.20 & \\
\hline TEXAS WEST SOUR & 22.00 & 32.2 & ROAD OIL \& ASPHALT & 17.97 & $<167.8$ \\
\hline OKLAHOMA CEMENT & 21.78 & 10.7 & SULFUR & 54.01 & \\
\hline CALIFORNIA ELK HILLS & 22.42 & 20.8 & & & \\
\hline NATURAL GAS (FOE) & 18.74 & & & & \\
\hline NATURAL GASOLINE & 19.66 & $<43.5$ & & & \\
\hline ISOBUTANE & 22.41 & $<50.1$ & & & \\
\hline NORMAL BUTANE & 20.10 & & & & \\
\hline ETHANOL & 29.92 & & & & \\
\hline NAPHTHA/REF FEED & 22.79 & $<36.8$ & & & \\
\hline GAS OIL MED $S$ & 23.37 & $<30.1$ & & & \\
\hline
\end{tabular}


Table 13. PADD II process capacity for year 2006 winter MTBE ban

\begin{tabular}{|c|c|}
\hline PROCESS & $\begin{array}{c}\text { CAPACITY } \\
\text { MBSD }\end{array}$ \\
\hline CRUDE DISTILLATION & 4008.5 \\
\hline VACUUM DISTILLATION & 1491.4 \\
\hline FLUID CAT CRACKER & 1555.9 \\
\hline MEROX & $>0.0$ \\
\hline HYDROCRACKER-2 STAGE & 325.4 \\
\hline HYDROCRACKER-LOW CONVER & 12.5 \\
\hline COKER-DELAYED & 427.6 \\
\hline SOLVENT DEASPHALTING & 37.4 \\
\hline LUBE + WAX PLANTS & 34.5 \\
\hline NAPHTHA HYDROTREATER & 1319.0 \\
\hline DISTILLATE HDS & 764.6 \\
\hline MID DIST DEEP HT & 326.0 \\
\hline FCC FEED HYDROFINER & 540.0 \\
\hline ATM RESID DESULF & 66.8 \\
\hline HP SEMI REGEN REFORMER & 279.3 \\
\hline LP CYCLIC REFORMER & 155.3 \\
\hline LP CONTINUOUS REFORMER & 629.8 \\
\hline ALKYLATION PLANT & 351.5 \\
\hline CAT POLYMERIZATION & $13 \cdot 6$ \\
\hline DIMERSOL & 5.2 \\
\hline BUTANE ISOMERIZATION & 22.7 \\
\hline PEN/HEX ISOMERIZATION & 258.5 \\
\hline AROMATICS RECOVERY (BTX) & 51.2 \\
\hline MTBE (ETHEROL) & 13.8 \\
\hline OCTGAIN & 0.0 \\
\hline GASOLINE SYNSAT & 0.0 \\
\hline CDTECH/FCC NAPHTHA DESUL & 464.1 \\
\hline ALKY OF BENZENE & 0.0 \\
\hline REFORMATE SPLITTER & 297.9 \\
\hline NAPHTHA SPLITTER & 173.0 \\
\hline FCC GASOLINE SPLR & 284.6 \\
\hline HYDROGEN PLT, MBPD FOE & 27.8 \\
\hline SULFUR PLANT, MST/D & 6.6 \\
\hline
\end{tabular}


Table 14. PADD I+ III specifications for emissions performance standards for year 2006

\begin{tabular}{|c|c|}
\hline Summer & Winter \\
\hline 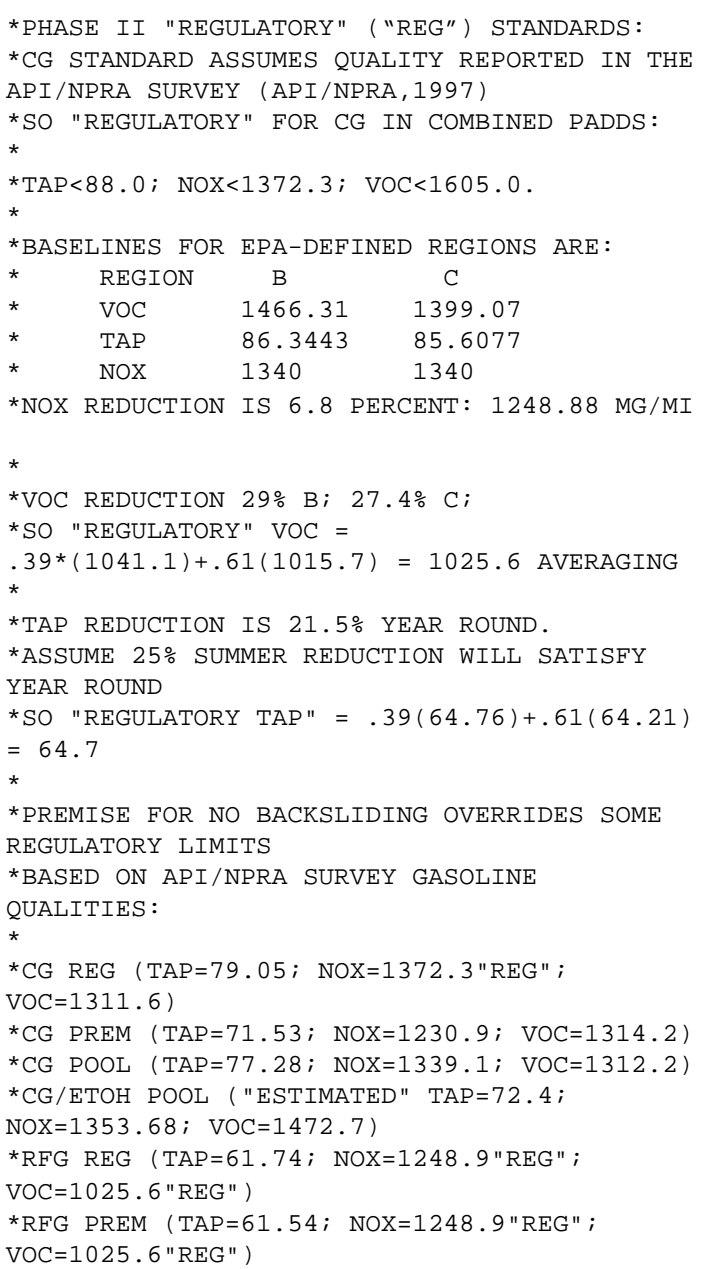 & $\begin{array}{l}\text { *ABSENT BACKSLIDING DATA, USE BASELINE } \\
\text { FACTORS: WINTER/SUMMER }=1540 / 1340 \text { FOR NOX; } \\
\text { 127.24/86.64 FOR TAP. } \\
\text { *WINTER CG POOL (TAP=113.5; NOX=1540) } \\
\text { *WINTER CG/ETOH POOL ("ESTIMATED" TAP=106.3; } \\
\text { NOX=1555.7) } \\
\text { *WINTER RFG REG (TAP=90.67; NOX=1516.9, A } \\
\text { 1.5\% REDUCTION) } \\
\text { *WINTER RFG PREM (TAP=90.37; NOX=1516.9, A } \\
\text { 1.5\% REDUCTION) }\end{array}$ \\
\hline
\end{tabular}


Table 15. PADD II specifications for emissions performance standards for year 2006

\begin{tabular}{|c|c|}
\hline Summer & Winter \\
\hline 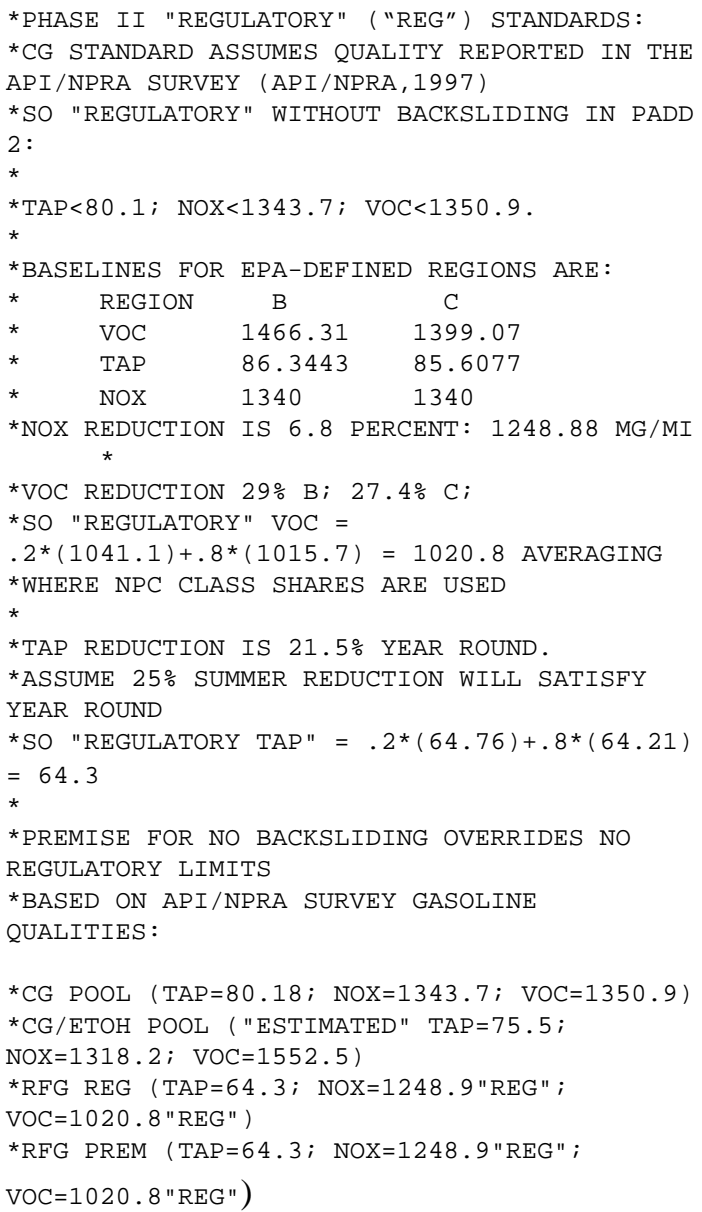 & $\begin{array}{l}\text { *ABSENT BACKSLIDING DATA, USE BASELINE } \\
\text { FACTORS: WINTER/SUMMER }=1540 / 1340 \text { FOR NOX; } \\
127.24 / 86.64 \text { FOR TAP. } \\
\text { *WINTER CG POOL (TAP=117.8; NOX=1544) } \\
\text { *WINTER CG/ETOH POOL ("ESTIMATED" TAP }=110.9 ; \\
\text { NOX=1514.9) } \\
\text { *WINTER RFG REG (TAP=94.43; NOX=1516.9, A } \\
\text { 1.5\% REDUCTION) } \\
\text { *WINTER RFG PREM (TAP }=94.43 ; \text { NOX=1516.9, A } \\
1.5 \% \text { REDUCTION) }\end{array}$ \\
\hline
\end{tabular}

1996 American Petroleum Institute/National Petroleum Refiners Association Survey of Refining Operations and Product Quality (API/NPRA, 1997).

For a given case, the model represents up to six gasolines (see Table 16).

All gasolines contain no more than 30 parts per million (ppm) sulfur, on average.

Gasoline properties are weighted to reflect the Class splits assumed in the National Petroleum Council (NPC) study of U.S. Petroleum Refining (NPC, 1993). Class splits account for differences in properties of gasolines produced for consumers in different climatic regions.

Specifications for products other than gasoline are based on the NPC study (NPC, 1993). 
Table 16. Study case design

\begin{tabular}{|c|c|c|c|c|c|c|}
\hline Case & 1 & 2 & 3 & 4 & 5 & 6 \\
\hline General & Reference & $\begin{array}{c}3 \% \text { vol max } \\
\text { MTBE }\end{array}$ & $\begin{array}{c}3 \% \text { vol max } \\
\text { MTBE }\end{array}$ & Reference & Ether Ban & Ether Ban \\
\hline PADD & $\mathrm{I}+\mathrm{III}$ & I+III & I+III & II & II & II \\
\hline Year & 2006 & 2006 & 2006 & 2006 & 2006 & 2006 \\
\hline Season & Sum & Sum & Win & Sum & Sum & Win \\
\hline RFG oxygen wt $\%$,ab & $2.1-2.7$ & $\begin{array}{l}0-3.5(\mathrm{E}) \\
<0.5(\mathrm{M})\end{array}$ & $\begin{array}{l}0-3.5(\mathrm{E}) \\
<0.5(\mathrm{M})\end{array}$ & $2.1-3.5$ & $0-3.5$ & $0-3.5$ \\
\hline CG oxygen wt $\%^{\mathrm{a}}$ & $0-2.7$ & $0-3.5$ & $0-3.5$ & $0-3.5$ & $0-3.5$ & $0-3.5$ \\
\hline Vol\% ethanol in $\mathrm{CG}^{\mathrm{c}}$ & N/A & 10 & 10 & 10 & 10 & 10 \\
\hline Gasoline oxygenate & MTBE & $\begin{array}{c}\text { EtOH } \\
\text { MTBE }\end{array}$ & $\begin{array}{c}\text { EtOH } \\
\text { MTBE }\end{array}$ & $\begin{array}{c}\text { EtOH } \\
\text { MTBE }\end{array}$ & $\mathrm{EtOH}$ & $\mathrm{EtOH}$ \\
\hline $\begin{array}{l}\text { Gasoline } \\
\text { pools }^{\text {b }}\end{array}$ & $\begin{array}{c}\text { CG-M } \\
\text { CG-E } \\
\text { RFG-M-R } \\
\text { RFG-M-P } \\
\text { RFG-E-R } \\
\text { RFG-E-P }\end{array}$ & $\begin{array}{c}\text { CG-M } \\
\text { CG-E } \\
\text { RFG-M-R } \\
\text { RFG-M-P } \\
\text { RFG-E-R } \\
\text { RFG-E-P }\end{array}$ & $\begin{array}{c}\text { CG-M } \\
\text { CG-E } \\
\text { RFG-M-R } \\
\text { RFG-M-P } \\
\text { RFG-E-R } \\
\text { RFG-E-P }\end{array}$ & $\begin{array}{c}\text { CG-M } \\
\text { CG-E } \\
\text { RFG-M-R } \\
\text { RFG-M-P } \\
\text { RFG-E-R } \\
\text { RFG-E-P }\end{array}$ & $\begin{array}{c}\text { CG-N } \\
\text { CG-E } \\
\text { RFG-N-R } \\
\text { RFG-N-P } \\
\text { RFG-E-R } \\
\text { RFG-E-P }\end{array}$ & $\begin{array}{c}\text { CG-N } \\
\text { CG-E } \\
\text { RFG-N-R } \\
\text { RFG-N-P } \\
\text { RFG-E-R } \\
\text { RFG-E-P }\end{array}$ \\
\hline RFG share & \multicolumn{6}{|c|}{ Current } \\
\hline Economic premises & \multicolumn{6}{|c|}{ AEO Reference } \\
\hline Ethanol cost & N/A & Vary & Vary & Vary & Vary & Vary \\
\hline Other & \multicolumn{6}{|c|}{ Ratio-free refinery model/ low sulfur gasoline/ no toxics backsliding } \\
\hline $\begin{array}{l}{ }^{\mathrm{a}} \text { Oxygen content in et } \\
{ }^{\mathrm{b}} \mathrm{R}=\text { regular grade } \mathrm{P}=\mathrm{1} \\
{ }^{\mathrm{c}} \text { With RVP waiver }(\mathrm{a}\end{array}$ & containing & ine is restric & to current ta & $\begin{array}{l}\text { MTBE; } \mathrm{N}=\mathrm{C} \\
\text { MTive lev }\end{array}$ & aining no o & $\begin{array}{l}\text { nate. } \\
\text { ol. }\end{array}$ \\
\hline
\end{tabular}

\subsection{REFINERY RAW MATERIALS}

Refinery inputs of crude oil and raw materials are based on Petroleum Supply Annual 1998 (U.S. DOE, 1999a). Refinery inputs are projected to year 2006 by using the Reference Case growth rates published in the Annual Energy Outlook 1999 (U.S. DOE, 1999b). The crude oil mix is based on the regional mixes reported by the NPC study (NPC, 1993).

\subsection{PRODUCT REVENUE AND RAW MATERIAL COSTS}


Revenues and costs are expressed in 1997 dollars. Raw material and crude oil costs are based on the Annual Energy Outlook 1999 (U.S. DOE, 1999b), the NPC study (NPC, 1993), Petroleum Marketing Annual (U.S. DOE, 1999c), and requested guidance from the Energy Information Administration. Product prices are based on the Annual Energy Outlook 1999 (U.S. DOE, 1999b), Petroleum Marketing Annual (U.S. DOE, 1999c), historical price differentials, price ratios, heating values, estimates reported by the NPC study (NPC, 1993), and requested guidance from the Energy Information Administration. Ethanol price is based on its octane value relative to gasoline, and it is assumed that there is a 0.3 percent increase in ethanol price with a 1 percent increase in volume. The ethanol price response does not affect estimation of the demand curves, which span a wide range of ethanol values. The demand curves will be used by other researchers who will apply more rigorous price elasticities of supply to determine supply/demand balance. This study reports the refiner/blender's net cost of ethanol, which includes allowance for federal tax exemptions.

\subsection{FEDERAL TAX IMPLICATIONS FOR ETHANOL CONCENTRATIONS}

Federal tax incentives that are targeted for motor fuels containing biomass alcohol are (1) a partial exemption from the federal motor fuel excise taxes that are earmarked for the Highway Trust Fund and (2) a set of three credits against income tax. The partial excise tax exemption has been much more important than the income tax credits in terms of the amount of benefits claimed. The size of the partial exemption depends on how much and what type of alcohol is contained in each gallon of fuel. Currently, motor fuels consisting of at least 10 percent biomass-derived ethanol are exempt from 5.4 cents of the per gallon federal excise tax on gasoline, and other motor fuels that are earmarked for the Highway Trust Fund. The exemption is also available for blends containing 5.7 or 7.7 percent ethanol (these blends correspond to the oxygen content standards for gasoline sold in ozone nonattainment and carbon monoxide nonattainment areas under the CAAA). For these three blends, the exemptions provide a subsidy of 54 cents per gallon of ethanol. Smaller subsidies are provided for blends with ethanol contents which are different from 5.7, 7.7 or 10 percent (U.S. GAO, 1997). In this ethanol demand study, it is assumed that the partial excise tax exemption is available for ethanol blended at $5.7,7.7$ or 10 percent.

\subsection{REFINERY CAPACITY}

Refinery capacity is based on in-place capacity and construction as reported in Refinery Capacity Data 1999 (U.S. DOE, 1999d), the NPC study (NPC, 1993), the NPRA survey (NPRA, 1991), the Oil \& Gas Journal (Radler, 1998 and 1999), or the survey report of American Petroleum Institute and NPRA (API/NPRA, 1997). Capacities for reformate splitter, FCC naphtha splitter, and straight run naphtha splitter are set at the greater of 
capacities reported in NPRA (NPRA, 1991) or in the NPC study (NPC, 1993). Refinery capacity for recovery of hydrogen is based on the API/NPRA survey (API/NPRA, 1997).

Process capacity investment is based on a 15 percent discounted cash flow rate of return on investment (ROI), and actual investment cost is based on a 10 percent ROI. For existing capacity, typical investment costs are used for up to 20 percent expansion in capacity. For capacity greater than the defined expansion limit, investment is subject to economies of scale, according to the "six-tenths factor" relationship:

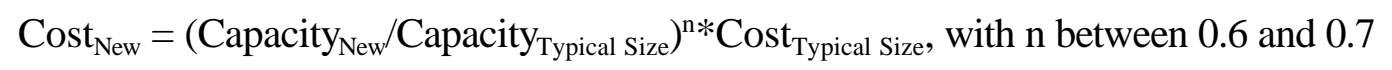

New capacity and expansions are averaged over all refineries in a region. Investment options include long-established and widely used technologies, plus the more recently developed FCC naphtha desulfurization processes, such as CDTECH's CDHydro+CDH2S and the Mobil Oil Octgain 220 process, with performance and costs as reported by process licensors in the fall of 1998.

\subsection{STUDY CASES}

Study cases are summarized in Table 16. These cases estimate refinery demand curves for ethanol in a low sulfur gasoline world; with or without partial or full ether ban; and with or without an oxygen content specification. Only summer reference cases are examined, to estimate impacts for the most stressed season. Winter cases provide estimates of winter ethanol demand rather than impacts relative to a reference case. It is assumed that the 1 pound per square inch (psi) RVP waiver causes all ethanol-containing CG to have 10 percent ethanol.

The Reference Case 1 provides the basis for estimating the PADD I+III refinery process configuration in summer of year 2006, given Phase 2 gasoline and oxygen requirements; with no toxics backsliding relative to 1996; and without an oxygenate ban.

In Case 2, the refinery process configuration determined in Case 1 is used (with further investment allowed) to examine PADD I+III gasoline production in summer of year 2006, given Phase 2 gasoline requirements; with only an upper limit on oxygen content; with no toxics backsliding relative to 1996; and with a maximum allowable 3 volume (vol) percent MTBE in all gasoline.

In Case 3, the refinery process configuration determined in Case 2 is used (with no further investment allowed) to examine PADD I+III gasoline production in winter of year 2006, given Phase 2 gasoline requirements; with no toxics backsliding relative to 1996; and with a maximum allowable 3 vol percent MTBE in all gasoline. 
The Reference Case 4 provides the basis for estimating the PADD II refinery process configuration in summer of year 2006, given Phase 2 gasoline and oxygen requirements; with no toxics backsliding relative to 1996; and without an oxygenate ban.

In Case 5, the refinery process configuration determined in Case 4 is used (with further investment allowed) to examine PADD II gasoline production in summer of year 2006, given Phase 2 gasoline requirements; with only an upper limit on oxygen content; with no toxics backsliding relative to 1996; and with a ban on MTBE.

In Case 6, the refinery process configuration determined in Case 5 is used (with no further investment allowed) to examine PADD II gasoline production in winter of year 2006, given Phase 2 gasoline requirements; with only an upper limit on oxygen content; with no toxics backsliding relative to 1996; and with a ban on MTBE. 


\section{THE DEMAND FOR ETHANOL USED IN U.S. REGIONAL OXYGENATE-LIMITED GASOLINE PRODUCTION IN YEAR 2006}

\subsection{READER GUIDANCE}

This report's seasonal ethanol demand volumes are derived from model analysis of an average day in a particular season. The seasonal demand is multiplied by 365 for a year-based seasonal demand which is plotted in the figures. Annualized demand volumes are derived by weighting the seasonal demand volumes, and expressing as an annual demand which is plotted in the figures. Annualized demand is the best estimate of actual demand for the entire year, taking into account seasonal effects. For example, if the summer season is 5.5 months, then:

Annual demand $=5.5 / 12 *($ Summer demand, year-based $)+6.5 / 12 *($ Winter demand, year based $)$.

The impacts of the winter-summer transition season are difficult to analyze and are not considered in this report.

\subsection{PADD I+III, SUMMER REFERENCE CONDITIONS}

PADD I is a 17 state area in the U.S. East Coast, and PADD III consists of six states, most of which are located on the Gulf Coast. This study assumes that there are 74 operable refineries in these combined regions, which produce 56 percent of all gasoline manufactured in the United States.

The solid line in Fig. 1 shows the ORNL-RYM estimate of the demand curve for ethanol used in PADD I+III gasoline production in year 2006 for summer Reference conditions. Demand curves are produced with a parametric linear programming feature that recomputes a solution with incremental increases in the refiner value of ethanol. With the parametric technique, ethanol blending properties, pollutant emission blending properties, and costs per unit of refinery process investment must be held constant. Nevertheless, past studies have confirmed that individual case study results agree well with parametrically generated demand curves (Hadder, 1998).

The price responsive value of ethanol is an illustrative estimate of the price (and refiner value) of ethanol. It is assumed that the pre-tax price of ethanol increases 0.3 percent for each 1.0 percent increase in volume, relative to the reference price and volume for a given 


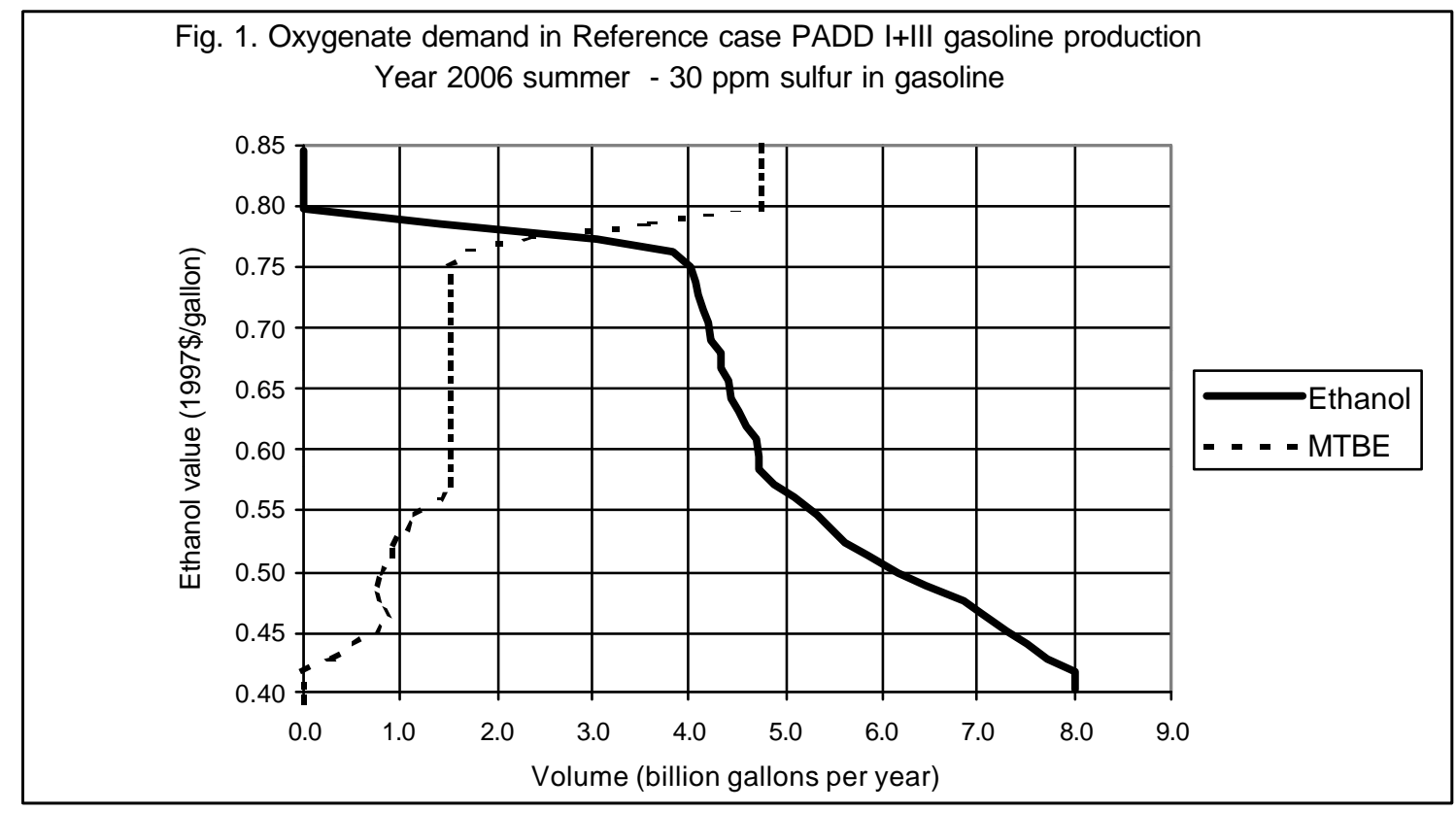

season and region. At $\$ 0.80$ per gallon (the price responsive value), ethanol demand is zero. [Supply/demand crossover analysis is beyond the scope of this study. Such analysis can be done with the Ethanol Industry Evolution Systems Analysis Spreadsheet, a tool to examine the key determinants, costs, and growth characteristics of an evolving ethanol industry in the United States (TMS, 1998).]

At refiner values below $\$ 0.42$ per gallon, ethanol demand is $8.0 \mathrm{BGY}$, and the ethanol concentration in the total gasoline pool is 10 vol percent. Fig. 1 shows how demand for MTBE, at a constant price, decreases as the price of ethanol falls. With an elastic MTBE price, the demand for MTBE would be greater and the demand for ethanol would be lower than shown in Fig. 1, as the value of ethanol falls. Consistent with prior work (Hadder, 1998), marginal cost results show that volatility limits make summer RFG more difficult and expensive to produce with high-RVP oxygenates like ethanol; ethanol's value in CG is enhanced by the 1 psi RVP waiver for 10 vol percent ethanol blends; and the demand for ethanol increases with sulfur reduction in gasoline (given the yield and octane losses premised for the model's gasoline sulfur reduction technologies).

Fig. 2 shows that, for summer Reference conditions, CG is the source of greatest demand for ethanol over the entire range of ethanol values. At maximum ethanol demand, RFG accounts for 25 percent of total demand for ethanol in gasoline blending. The disaggregation of demand in Fig. 2 will be useful in mapping ethanol production into ethanol demand regions, characterized on the basis of ozone non-attainment.

Key results for the summer Reference and all other cases are summarized in Tables 17 through 25 , which show gasoline properties, blendstocks, refinery volume balances, 


\begin{tabular}{|c|c|c|c|}
\hline \multicolumn{4}{|c|}{ Table 17. Gasoline ${ }^{a}$ properties } \\
\hline & \multicolumn{3}{|c|}{$\begin{array}{c}\text { Case 1. Reference/PADD } \\
\text { I+III/Sum } \\
\end{array}$} \\
\hline & \multirow{2}{*}{$\begin{array}{l}\text { CG/ } \\
\text { MTBE }\end{array}$} & \multicolumn{2}{|c|}{ RFG/MTBE } \\
\hline & & Reg & Prem \\
\hline Volume, MBD & 3802 & 879 & 395 \\
\hline Volume, $\%$ & 74.9 & 17.3 & 7.8 \\
\hline Octane, $(\mathrm{R}+\mathrm{M}) / 2$ & 88.7 & 88.2 & 94.2 \\
\hline RVP, psi & 8.2 & 7.3 & 7.3 \\
\hline Aromatics, vol \% & 32.3 & 18.0 & 19.3 \\
\hline Benzene, vol \% & 1.83 & 0.95 & 0.95 \\
\hline Olefins, vol \% & 6.8 & 19.0 & 19.0 \\
\hline Sulfur, ppm & 30 & 30 & 30 \\
\hline $\mathrm{E} 200, \%$ & 55.3 & 59.7 & 59.7 \\
\hline $\mathrm{E} 300, \%$ & 83.1 & 88.8 & 87.7 \\
\hline Oxygen, wt \% & 0.81 & 2.01 & 2.00 \\
\hline Specific gravity & .7464 & .7274 & .7294 \\
\hline $\begin{array}{l}\text { Summer TAP, } \\
\mathrm{mg} / \mathrm{mi}\end{array}$ & $77.3^{\mathrm{b}}$ & 57.4 & 57.9 \\
\hline NOx, mg/mi & 1191 & 1242 & $1249^{b}$ \\
\hline $\mathrm{VOC}, \mathrm{mg} / \mathrm{mi}$ & 1242 & $1026^{\mathrm{b}}$ & $1025^{\mathrm{b}}$ \\
\hline $\begin{array}{l}\text { a Model had option } \\
\text { types. } \\
{ }^{\text {b Binding emissions }}\end{array}$ & $\begin{array}{l}\text { produce a } \\
\text { onstraint. }\end{array}$ & of six & oline \\
\hline
\end{tabular}




\begin{tabular}{|c|c|c|c|c|c|c|}
\hline \multicolumn{7}{|c|}{ Table 17 (Continued). Gasoline properties } \\
\hline & \multicolumn{6}{|c|}{ Case 2. $3 \%$ vol max MTBE/PADD I+III/Sum } \\
\hline & \multicolumn{2}{|c|}{ CG } & \multicolumn{2}{|c|}{ RFG/MTBE } & \multicolumn{2}{|c|}{$\mathrm{RFG/EtOH}$} \\
\hline & $\begin{array}{c}\text { MTB } \\
\text { E }\end{array}$ & $\mathrm{EtOH}$ & Reg & Prem & Reg & Prem \\
\hline Volume, MBD & 3566 & 232 & 637 & 286 & 234 & 106 \\
\hline Volume, $\%$ & 70.4 & 4.6 & 12.6 & 5.6 & 4.7 & 2.1 \\
\hline Octane, $(\mathrm{R}+\mathrm{M}) / 2$ & 88.7 & 88.5 & 88.2 & 94.7 & 87.9 & 93.7 \\
\hline RVP, psi & 8.2 & 9.2 & 6.9 & 7.0 & 7.3 & 7.1 \\
\hline Aromatics, vol \% & 33.4 & 26.0 & 22.5 & 26.3 & 24.3 & 23.8 \\
\hline Benzene, vol \% & 1.71 & 1.76 & 0.65 & 0.91 & 0.95 & 0.73 \\
\hline Olefins, vol \% & 8.0 & 3.8 & 19.0 & 9.5 & 17.7 & 19.0 \\
\hline Sulfur, ppm & 30 & 30 & 30 & 30 & 30 & 29 \\
\hline E200, \% & 54.8 & 59.7 & 44.0 & 60.2 & 59.7 & 46.5 \\
\hline $\mathrm{E} 300, \%$ & 83.5 & 90.6 & 82.0 & 87.3 & 89.3 & 87.8 \\
\hline Oxygen, wt $\%$ & 0.54 & 3.53 & 0.55 & 0.55 & 3.50 & 3.47 \\
\hline Specific gravity & .7449 & .7457 & .7369 & .7360 & .7513 & .7587 \\
\hline $\begin{array}{l}\text { Summer TAP, } \\
\mathrm{mg} / \mathrm{mi}\end{array}$ & $77.3^{\mathrm{a}}$ & $72.4^{\mathrm{a}}$ & $61.6^{\mathrm{a}}$ & $61.7^{\mathrm{a}}$ & $61.6^{\mathrm{a}}$ & $61.4^{\mathrm{a}}$ \\
\hline $\mathrm{NOx}, \mathrm{mg} / \mathrm{mi}$ & 1195 & 1175 & $1249^{a}$ & 1189 & $1249^{\mathrm{a}}$ & $1249^{\mathrm{a}}$ \\
\hline $\mathrm{VOC}, \mathrm{mg} / \mathrm{mi}$ & 1241 & 1418 & $1024^{\mathrm{a}}$ & $1026^{\mathrm{a}}$ & $1025^{\mathrm{a}}$ & $1024^{\mathrm{a}}$ \\
\hline
\end{tabular}




\begin{tabular}{|c|c|c|c|c|c|}
\hline \multicolumn{6}{|c|}{ Table 17 (Continued). Gasoline ${ }^{\mathrm{a}}$ properties } \\
\hline & \multicolumn{5}{|c|}{$\begin{array}{c}\text { Case 3. 3\% vol max MTBE/PADD } \\
\text { I+III/Win }\end{array}$} \\
\hline & \multirow{2}{*}{$\begin{array}{c}\text { CG } \\
\text { MTB } \\
\text { E }\end{array}$} & \multicolumn{2}{|c|}{ RFG/MTBE } & \multicolumn{2}{|c|}{$\mathrm{RFG/EtOH}$} \\
\hline & & $\operatorname{Reg}$ & Prem & Reg & Prem \\
\hline Volume, MBD & 3557 & 279 & 125 & 651 & 292 \\
\hline Volume, \% & 72.5 & 5.7 & 2.6 & 13.3 & 6.0 \\
\hline Octane, $(\mathrm{R}+\mathrm{M}) / 2$ & 88.8 & 88.7 & 94.4 & 87.3 & 93.2 \\
\hline RVP, psi & 12.6 & 12.6 & 12.6 & 13.6 & 13.6 \\
\hline Aromatics, vol \% & 31.7 & 22.2 & 19.3 & 18.6 & 18.0 \\
\hline Benzene, vol \% & 1.81 & 0.77 & 0.92 & 0.95 & 0.86 \\
\hline Olefins, vol \% & 9.6 & 3.8 & 13.8 & 15.0 & 19.0 \\
\hline Sulfur, ppm & 30 & 30 & 30 & 30 & 30 \\
\hline E200, \% & 59.7 & 60.2 & 59.7 & 59.6 & 59.7 \\
\hline $\mathrm{E} 300, \%$ & 83.8 & 85.3 & 88.6 & 88.5 & 89.5 \\
\hline Oxygen, wt $\%$ & 0.44 & 0.12 & 0.56 & 3.60 & 3.62 \\
\hline Specific gravity & .7354 & .7214 & .7201 & .7313 & .7261 \\
\hline $\begin{array}{l}\text { Winter TAP, } \\
\mathrm{mg} / \mathrm{mi}\end{array}$ & $113.4^{\mathrm{b}}$ & $90.6^{\mathrm{b}}$ & $90.4^{\mathrm{b}}$ & $90.6^{\mathrm{b}}$ & $90.4^{\mathrm{b}}$ \\
\hline NOx, mg/mi & 1371 & 1326 & 1359 & 1363 & 1413 \\
\hline
\end{tabular}




\begin{tabular}{|c|c|c|c|c|}
\hline \multicolumn{5}{|c|}{ Table 17 (Continued). Gasoline ${ }^{\mathrm{a}}$ properties } \\
\hline & \multicolumn{4}{|c|}{ Case 4. Reference/PADD II/Sum } \\
\hline & \multicolumn{2}{|c|}{$\mathrm{CG}$} & \multicolumn{2}{|c|}{ RFG/EtOH } \\
\hline & $\begin{array}{c}\text { MTB } \\
\text { E }\end{array}$ & $\mathrm{EtOH}$ & Reg & Prem \\
\hline Volume, MBD & 1264 & 450 & 252 & 113 \\
\hline Volume, \% & 61 & 22 & 12 & 5 \\
\hline Octane, $(\mathrm{R}+\mathrm{M}) / 2$ & 89.3 & 88.4 & 87.6 & 92.6 \\
\hline RVP, psi & 8.5 & 9.5 & 7.2 & 7.4 \\
\hline Aromatics, vol \% & 31.7 & 32.0 & 27.3 & 20.7 \\
\hline Benzene, vol \% & 1.95 & 1.70 & 0.95 & 0.95 \\
\hline Olefins, vol \% & 7.0 & 3.8 & 15.9 & 19.0 \\
\hline Sulfur, ppm & 30 & 30 & 30 & 23 \\
\hline $\mathrm{E} 200, \%$ & 59.7 & 59.7 & 59.7 & 59.7 \\
\hline $\mathrm{E} 300, \%$ & 84.6 & 88.6 & 88.4 & 89.0 \\
\hline Oxygen, wt $\%$ & 0.17 & 3.49 & 3.51 & 3.57 \\
\hline Specific gravity & .7402 & .7545 & .7487 & .7364 \\
\hline $\begin{array}{l}\text { Summer TAP, } \\
\mathrm{mg} / \mathrm{mi}\end{array}$ & $80.2^{\mathrm{b}}$ & $75.5^{\mathrm{b}}$ & 62.6 & 60.5 \\
\hline $\mathrm{NOx}, \mathrm{mg} / \mathrm{mi}$ & 1196 & 1189 & 1238 & 1248 \\
\hline $\mathrm{VOC}, \mathrm{mg} / \mathrm{mi}$ & 1267 & 1476 & $1021^{\mathrm{b}}$ & $1021^{\mathrm{b}}$ \\
\hline
\end{tabular}




\begin{tabular}{|c|c|c|c|c|}
\hline \multicolumn{5}{|c|}{ Table 17 (Continued). Gasoline ${ }^{\mathrm{a}}$ properties } \\
\hline & \multicolumn{4}{|c|}{ Case 5. Ether Ban/PADD II/Sum } \\
\hline & \multicolumn{2}{|c|}{$\mathrm{CG}$} & \multicolumn{2}{|c|}{ RFG/EtOH } \\
\hline & $\begin{array}{c}\text { MTB } \\
\text { E }\end{array}$ & $\mathrm{EtOH}$ & Reg & Prem \\
\hline Volume, MBD & 1235 & 478 & 252 & 113 \\
\hline Volume, \% & 59 & 23 & 12 & 5 \\
\hline Octane, $(\mathrm{R}+\mathrm{M}) / 2$ & 89.4 & 88.4 & 87.6 & 92.0 \\
\hline RVP, psi & 8.5 & 9.5 & 7.2 & 7.0 \\
\hline Aromatics, vol \% & 32.5 & 30.5 & 27.7 & 33.0 \\
\hline Benzene, vol \% & 1.88 & 1.77 & 0.95 & 0.95 \\
\hline Olefins, vol \% & 6.5 & 8.1 & 14.8 & 6.8 \\
\hline Sulfur, ppm & 30 & 30 & 30 & 30 \\
\hline $\mathrm{E} 200, \%$ & 59.7 & 59.7 & 59.2 & 60.2 \\
\hline $\mathrm{E} 300, \%$ & 84.2 & 88.6 & 88.4 & 89.3 \\
\hline Oxygen, wt $\%$ & 0.00 & 3.49 & 3.52 & 3.47 \\
\hline Specific gravity & .7391 & .7545 & .7480 & .7587 \\
\hline $\begin{array}{l}\text { Summer TAP, } \\
\mathrm{mg} / \mathrm{mi}\end{array}$ & $80.2^{\mathrm{b}}$ & $75.6^{\mathrm{b}}$ & 62.6 & 63.9 \\
\hline $\mathrm{NOx}, \mathrm{mg} / \mathrm{mi}$ & 1196 & 1195 & 1226 & 1186 \\
\hline $\mathrm{VOC}, \mathrm{mg} / \mathrm{mi}$ & 1273 & 1463 & $1021^{\mathrm{b}}$ & $1022^{b}$ \\
\hline
\end{tabular}




\begin{tabular}{|c|c|c|c|c|c|c|}
\hline \multicolumn{7}{|c|}{ Table 17 (Continued). Gasoline properties } \\
\hline & \multicolumn{6}{|c|}{ Case 6. Ether Ban/PADD II/Win } \\
\hline & \multicolumn{2}{|c|}{$\mathrm{CG}$} & \multicolumn{2}{|c|}{ RFG/MTBE } & \multicolumn{2}{|c|}{$\mathrm{RFG/EtOH}$} \\
\hline & MTBE & $\mathrm{EtOH}$ & Reg & Prem & Reg & Prem \\
\hline Volume, MBD & 1206 & 566 & 15 & 7 & 221 & 99 \\
\hline Volume, \% & 57 & 27 & 0.7 & 0.3 & 10 & 5 \\
\hline Octane, $(\mathrm{R}+\mathrm{M}) / 2$ & 89.6 & 88.7 & 87.3 & 92.6 & 87.3 & 92.0 \\
\hline RVP, psi & 13.1 & 14.1 & 13.1 & 13.1 & 14.1 & 14.1 \\
\hline Aromatics, vol \% & 30.1 & 24.2 & 23.0 & 27.0 & 26.0 & 26.2 \\
\hline Benzene, vol \% & 2.10 & 2.44 & 0.69 & 0.47 & 0.95 & 0.95 \\
\hline Olefins, vol \% & 5.6 & 6.2 & 19.0 & 19.0 & 15.6 & 6.8 \\
\hline Sulfur, ppm & 30 & 30 & 30 & 30 & 30 & 30 \\
\hline E200, \% & 59.7 & 59.7 & 60.2 & 59.9 & 59.7 & 59.7 \\
\hline $\mathrm{E} 300, \%$ & 84.2 & 91.5 & 82.0 & 85.5 & 91.9 & 86.4 \\
\hline Oxygen, wt $\%$ & 0.00 & 3.56 & 0.00 & 0.00 & 3.60 & 3.56 \\
\hline Specific gravity & .7279 & .7383 & .7271 & .7290 & .7312 & .7379 \\
\hline $\begin{array}{l}\text { Winter TAP, } \\
\mathrm{mg} / \mathrm{mi}\end{array}$ & $117.6^{\mathrm{a}}$ & $110.8^{\mathrm{a}}$ & $94.5^{\mathrm{a}}$ & $94.6^{\mathrm{a}}$ & $94.6^{\mathrm{a}}$ & $94.4^{\mathrm{a}}$ \\
\hline $\mathrm{NOx}, \mathrm{mg} / \mathrm{mi}$ & 1353 & 1328 & 1450 & 1462 & 1401 & 1340 \\
\hline
\end{tabular}




\begin{tabular}{|l||c|c|c|}
\hline \multicolumn{3}{|c|}{ Table 18. Gasoline ${ }^{\mathrm{a}}$ blendstocks } \\
(percent)
\end{tabular}


Table 18 (Continued). Gasoline blendstocks

(percent)

\begin{tabular}{|c|c|c|c|c|c|c|}
\hline & \multicolumn{6}{|c|}{ Case 2. $3 \%$ vol max MTBE/PADD I+III/Sum } \\
\hline & \multicolumn{2}{|c|}{ CG } & \multicolumn{2}{|c|}{ RFG/MTBE } & \multicolumn{2}{|c|}{ RFG/EtOH } \\
\hline & $\begin{array}{c}\text { MTB } \\
\text { E }\end{array}$ & $\mathrm{EtOH}$ & Reg & Prem & Reg & Prem \\
\hline $\mathrm{C} 4 \mathrm{~s}$ & 1.2 & 0.8 & 0.8 & 0.8 & 0.8 & 0.8 \\
\hline Reformate & 33.5 & 28.4 & 17.2 & 32.1 & 28.8 & 32.5 \\
\hline $\begin{array}{l}\text { Straight run } \\
\text { naphtha }\end{array}$ & 2.6 & 1.4 & 1.2 & & 13.2 & 4.0 \\
\hline $\mathrm{C} 5+$ isomerate & 11.8 & 5.0 & & & & \\
\hline FCC naphtha & 6.6 & & 26.3 & 16.6 & 25.1 & 14.1 \\
\hline $\begin{array}{l}\text { Desulfurized } \\
\text { FCC naphtha }\end{array}$ & 24.8 & 23.2 & 23.0 & & 10.0 & 2.5 \\
\hline \multicolumn{7}{|l|}{ Coker naphtha } \\
\hline Hydrocrackate & 8.6 & 28.1 & & & & \\
\hline Alkylate & 7.1 & 1.0 & 28.4 & 47.5 & 15.7 & 29.8 \\
\hline $\begin{array}{l}\text { Polymer } \\
\text { gasolines }\end{array}$ & 0.6 & 2.0 & & & 6.5 & 6.3 \\
\hline Dimate & 0.1 & & & & & \\
\hline MTBE & 3.0 & & 3.0 & 3.0 & & \\
\hline Ethanol & & 10.0 & & & 10.0 & 10.0 \\
\hline Natural gasoline & & & & & & \\
\hline
\end{tabular}


Table 18 (Continued). Gasoline ${ }^{a}$ blendstocks

(percent)

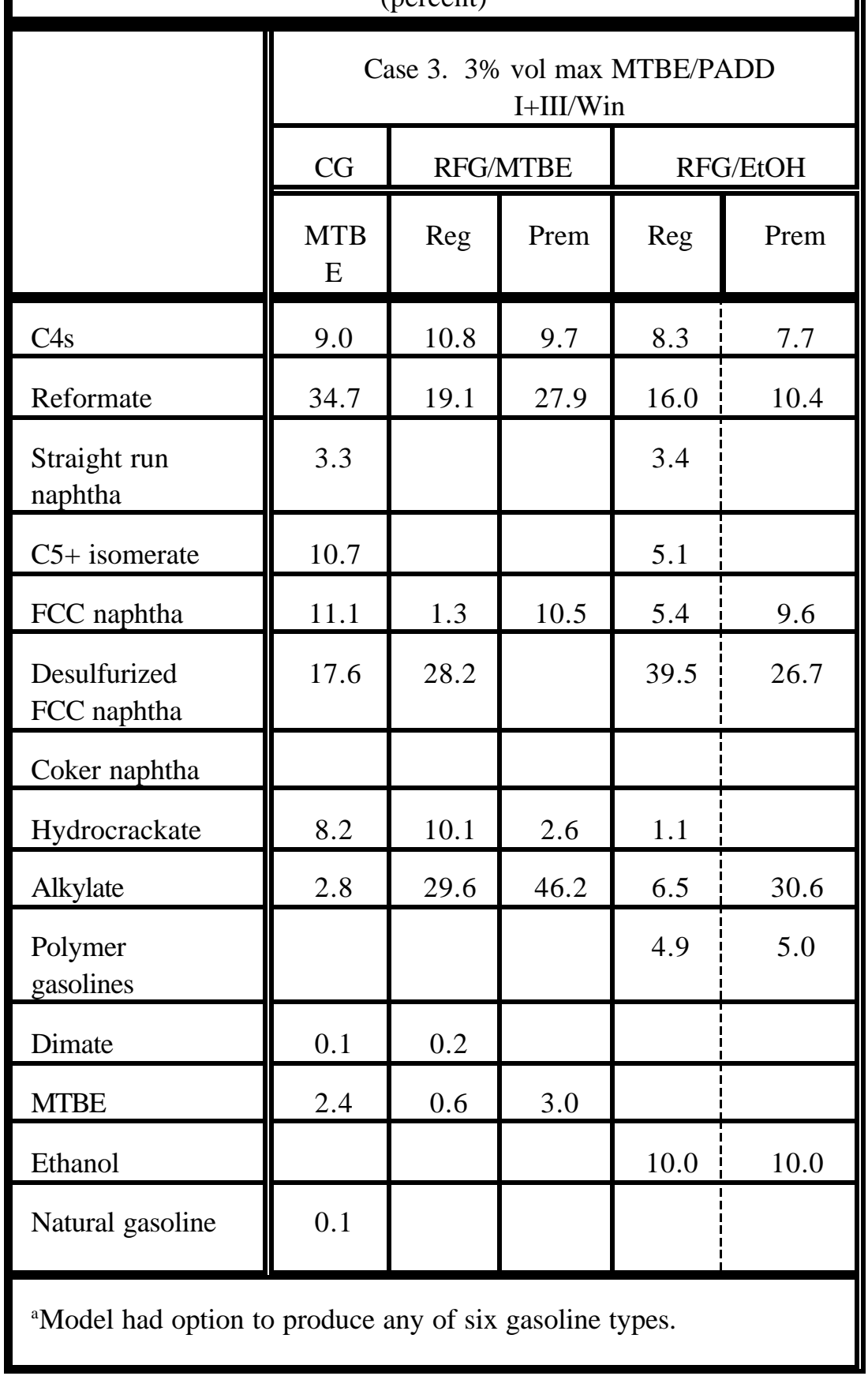


Table 18 (Continued). Gasoline ${ }^{a}$ blendstocks

(percent)

\begin{tabular}{|c|c|c|c|c|}
\hline & \multicolumn{4}{|c|}{ Case 4. Reference/PADD II/Sum } \\
\hline & \multicolumn{2}{|c|}{ CG } & \multicolumn{2}{|c|}{ RFG/EtOH } \\
\hline & $\begin{array}{c}\text { MTB } \\
\text { E }\end{array}$ & $\mathrm{EtOH}$ & Reg & Prem \\
\hline $\mathrm{C} 4 \mathrm{~s}$ & 2.2 & 1.4 & 0.8 & 0.8 \\
\hline Reformate & 36.2 & 34.2 & 19.8 & 15.4 \\
\hline $\begin{array}{l}\text { Straight run } \\
\text { naphtha }\end{array}$ & 3.4 & 5.5 & 3.5 & \\
\hline C5+ isomerate & 8.8 & 13.1 & 16.4 & \\
\hline FCC naphtha & 5.7 & 2.9 & 21.5 & 31.2 \\
\hline $\begin{array}{l}\text { Desulfurized } \\
\text { FCC naphtha }\end{array}$ & 18.7 & 24.5 & 15.6 & \\
\hline Coker naphtha & & & & \\
\hline Hydrocrackate & 7.6 & 6.6 & 9.4 & 2.8 \\
\hline Alkylate & 16.1 & & & 36.6 \\
\hline $\begin{array}{l}\text { Polymer } \\
\text { gasolines }\end{array}$ & & & 3.1 & 3.2 \\
\hline Dimate & 0.3 & & & \\
\hline MTBE & 0.9 & & & \\
\hline Ethanol & & 10.0 & 10.0 & 10.0 \\
\hline Natural gasoline & & 1.7 & & \\
\hline
\end{tabular}

${ }^{a}$ Model had option to produce any of six gasoline types. 
Table 18 (Continued). Gasoline ${ }^{a}$ blendstocks (percent)

\begin{tabular}{|c|c|c|c|c|}
\hline & \multicolumn{4}{|c|}{ Case 5. Ether Ban/PADD II/Sum } \\
\hline & \multicolumn{2}{|c|}{ CG } & \multicolumn{2}{|c|}{ RFG/EtOH } \\
\hline & $\begin{array}{c}\text { MTB } \\
\text { E }\end{array}$ & $\mathrm{EtOH}$ & Reg & Prem \\
\hline $\mathrm{C} 4 \mathrm{~s}$ & 2.0 & 1.6 & 0.8 & 0.8 \\
\hline Reformate & 34.5 & 35.5 & 20.2 & 30.3 \\
\hline $\begin{array}{l}\text { Straight run } \\
\text { naphtha }\end{array}$ & 3.9 & 5.3 & 2.8 & \\
\hline C5+ isomerate & 9.5 & 10.9 & 16.5 & \\
\hline FCC naphtha & 5.8 & 3.5 & 23.5 & 10.8 \\
\hline $\begin{array}{l}\text { Desulfurized } \\
\text { FCC naphtha }\end{array}$ & 20.1 & 21.5 & 13.7 & 16.2 \\
\hline \multicolumn{5}{|l|}{ Coker naphtha } \\
\hline Hydrocrackate & 7.6 & 5.5 & 9.7 & 13.9 \\
\hline Alkylate & 16.6 & 2.0 & & 18.1 \\
\hline $\begin{array}{l}\text { Polymer } \\
\text { gasolines }\end{array}$ & & 0.8 & 2.9 & \\
\hline Dimate & & 0.9 & & \\
\hline \multicolumn{5}{|l|}{ MTBE } \\
\hline Ethanol & & 10 & 10 & 10 \\
\hline Natural gasoline & & 2.5 & & \\
\hline
\end{tabular}

${ }^{a}$ Model had option to produce any of six gasoline types. 
Table 18 (Continued). Gasoline blendstocks

(percent)

\begin{tabular}{|c|c|c|c|c|c|c|}
\hline & \multicolumn{6}{|c|}{ Case 6. Ether Ban/PADD II/Win } \\
\hline & \multicolumn{2}{|c|}{$\mathrm{CG}$} & \multicolumn{2}{|c|}{ RFG/MTBE } & \multicolumn{2}{|c|}{ RFG/EtOH } \\
\hline & $\begin{array}{c}\text { MTB } \\
\text { E }\end{array}$ & $\mathrm{EtOH}$ & Reg & Prem & Reg & Prem \\
\hline $\mathrm{C} 4 \mathrm{~s}$ & 9.6 & 11.7 & 10.3 & 10.1 & 12.0 & 10.9 \\
\hline Reformate & 36.1 & 25.2 & 20.0 & 23.3 & 19.4 & 13.5 \\
\hline $\begin{array}{l}\text { Straight run } \\
\text { naphtha }\end{array}$ & & 2.5 & 4.3 & 8.6 & 10.4 & 0.1 \\
\hline C5+ isomerate & 13.8 & 0.7 & & & 13.5 & \\
\hline FCC naphtha & 7.2 & 0.4 & & 2.7 & 30.5 & 1.7 \\
\hline $\begin{array}{l}\text { Desulfurized } \\
\text { FCC naphtha }\end{array}$ & 14.1 & 29.0 & 39.8 & 14.9 & 2.1 & 40.6 \\
\hline \multicolumn{7}{|l|}{ Coker naphtha } \\
\hline Hydrocrackate & 6.7 & 13.2 & & & 1.7 & \\
\hline Alkylate & 12.4 & 5.4 & 10.8 & 24.5 & & 23.3 \\
\hline $\begin{array}{l}\text { Polymer } \\
\text { gasolines }\end{array}$ & & 1.9 & & & & \\
\hline Dimate & & & 14.8 & 15.8 & 0.4 & \\
\hline \multicolumn{7}{|l|}{ MTBE } \\
\hline Ethanol & & 10.0 & & & 10.0 & 10.0 \\
\hline Natural gasoline & & & & & & \\
\hline
\end{tabular}




\begin{tabular}{|c|c|c|c|}
\hline \multicolumn{4}{|c|}{$\begin{array}{l}\text { Table 19. Pooled gasoline }{ }^{a} \text { blendstocks } \\
\text { (percent) }\end{array}$} \\
\hline \multirow[t]{2}{*}{ Blendstock } & \multicolumn{3}{|c|}{ Case } \\
\hline & $\begin{array}{c}1 . \\
\text { Reference/PADD } \\
\text { I+III/Sum }\end{array}$ & $\begin{array}{c}2 . \\
3 \% \text { vol max MTBE/ } \\
\text { PADD I+III/Sum }\end{array}$ & $\begin{array}{c}3 . \\
\text { 3\% vol max MTBE/ } \\
\text { PADD I+III/Win }\end{array}$ \\
\hline $\mathrm{C} 4 \mathrm{~s}$ & 1.4 & 1.1 & 8.9 \\
\hline Reformate & 31.2 & 30.9 & 29.7 \\
\hline $\begin{array}{l}\text { Straight run } \\
\text { naphtha }\end{array}$ & 2.7 & 2.8 & 2.8 \\
\hline $\mathrm{C} 5+$ isomerate & 8.0 & 8.5 & 8.4 \\
\hline FCC naphtha & 10.1 & 10.4 & 9.7 \\
\hline $\begin{array}{l}\text { Desulfurized FCC } \\
\text { naphtha }\end{array}$ & 20.2 & 21.5 & 21.2 \\
\hline \multicolumn{4}{|l|}{ Coker naphtha } \\
\hline Hydrocrackate & 7.2 & 7.3 & 6.7 \\
\hline Alkylate & 12.1 & 12.6 & 7.6 \\
\hline Polymer gasolines & 1.0 & 1.0 & 0.9 \\
\hline Dimate & 0.1 & 0.1 & 0.1 \\
\hline MTBE & 6.1 & 2.7 & 1.9 \\
\hline Ethanol & & 1.1 & 1.9 \\
\hline Natural gasoline & & & 0.1 \\
\hline
\end{tabular}




\begin{tabular}{|l||c|c||}
\hline \multicolumn{4}{|c|}{ Table 19 (Continued). Pooled gasoline ${ }^{\mathrm{a}}$ blendstocks } \\
(percent)
\end{tabular}


Table 20. Refinery volume balance

(Thousand barrels per day)

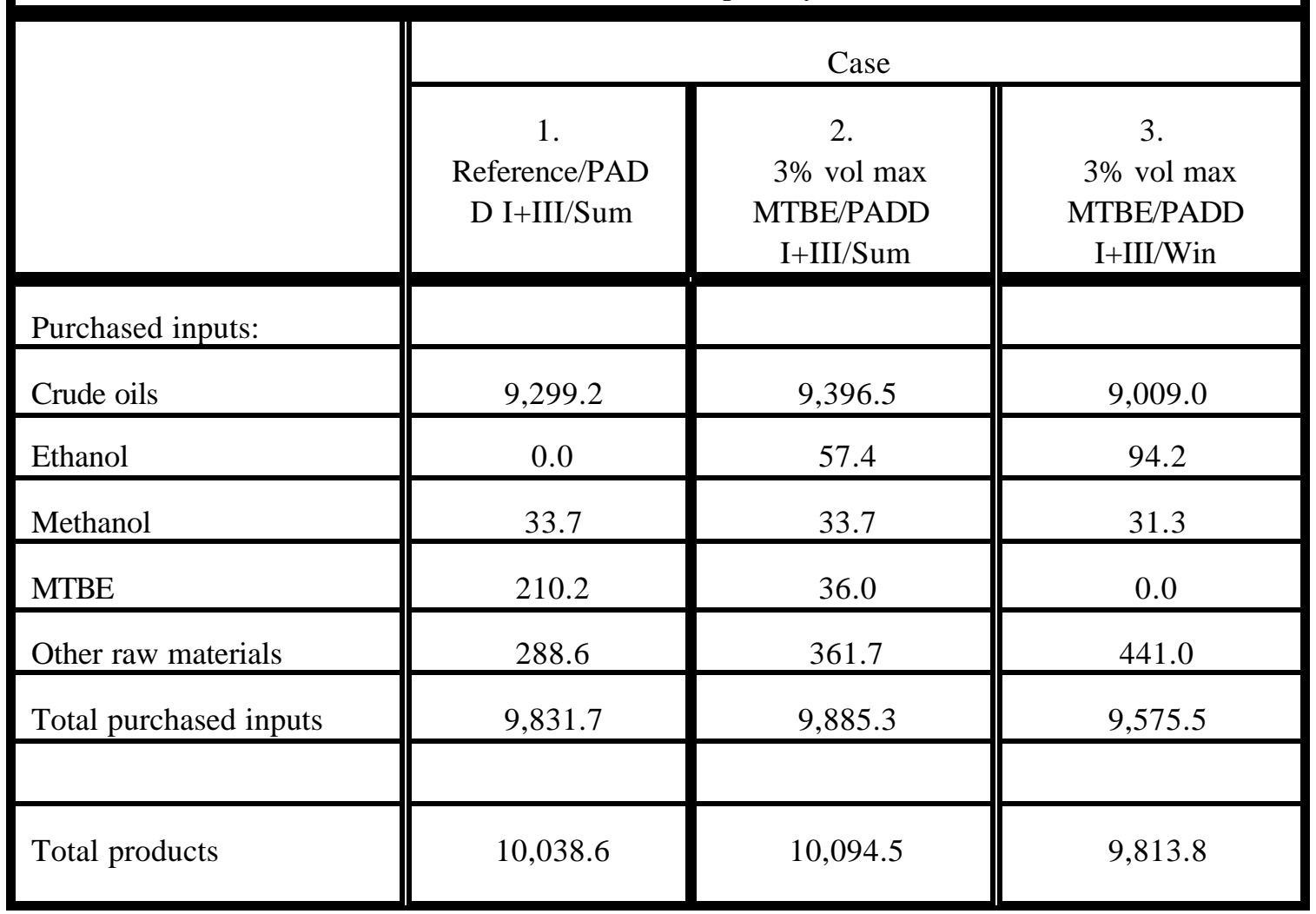


Table 20 (Continued). Refinery volume balance (Thousand barrels per day)

\begin{tabular}{|l||c|c||c|}
\cline { 2 - 4 } & \multicolumn{3}{c|}{ Case } \\
\cline { 2 - 4 } & $\begin{array}{c}4 . \\
\text { Reference/PAD } \\
\text { D II/Sum }\end{array}$ & $\begin{array}{c}\text { S. } \\
\text { Ether Ban/PADD } \\
\text { II/Sum }\end{array}$ & $\begin{array}{c}\text { Ether Ban/PADD } \\
\text { II/Win }\end{array}$ \\
\hline Purchased inputs: & & & \\
\hline Crude oils & $3,688.4$ & $3,702.7$ & $3,621.9$ \\
\hline Ethanol & 81.4 & 84.2 & 88.5 \\
\hline Methanol & 4.0 & 0.0 & 0.0 \\
\hline MTBE & 0.0 & 0.0 & 0.0 \\
\hline Other raw materials & 150.9 & 140.8 & 274.5 \\
\hline Total purchased inputs & $3,924.7$ & $3,927.7$ & $3,984.9$ \\
\hline & & & \\
\hline Total products & $3,986.1$ & $3,994.5$ & $4,065.5$ \\
\hline
\end{tabular}




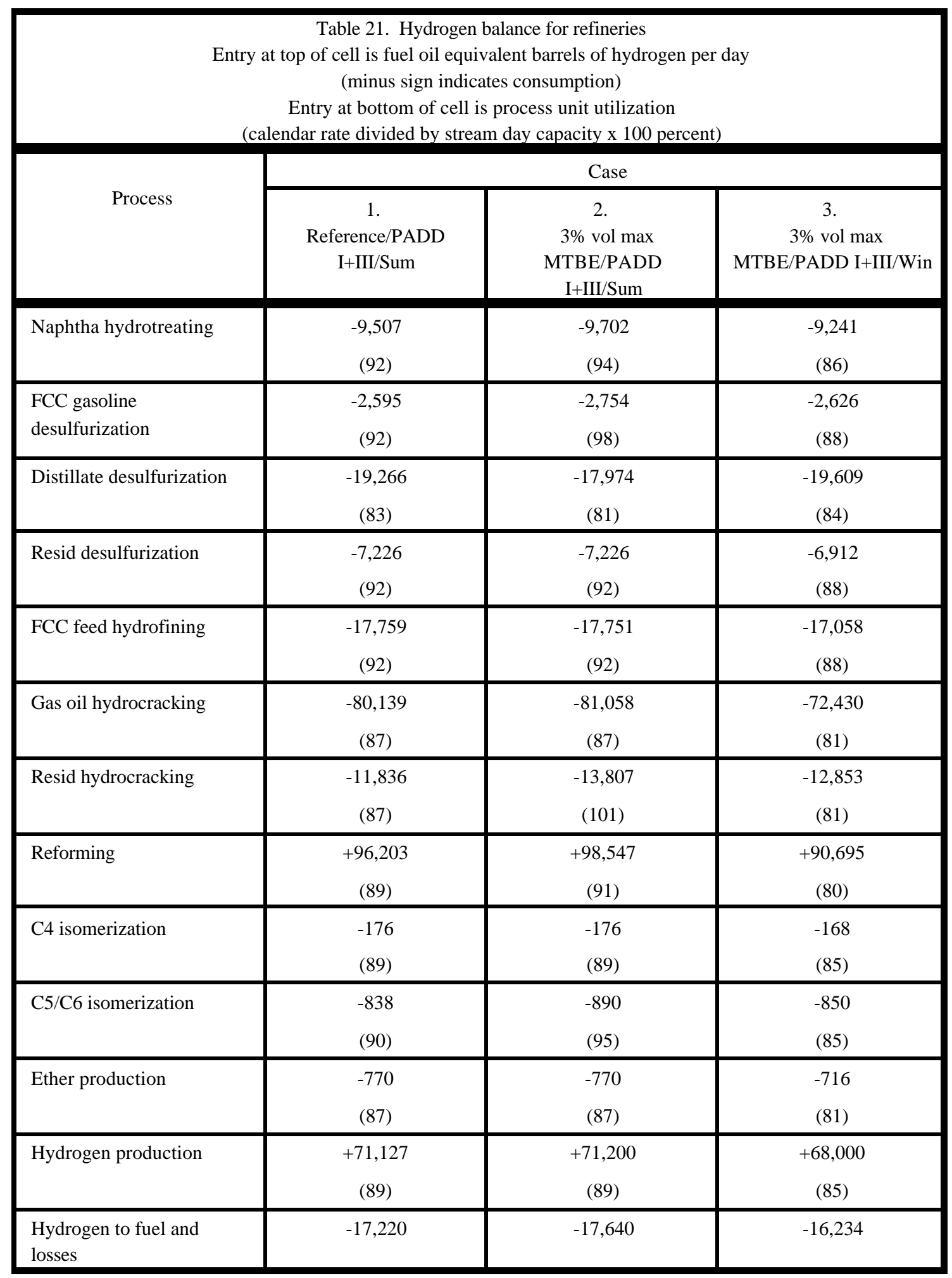




\begin{tabular}{|c|c|c|c|}
\hline \multicolumn{4}{|c|}{$\begin{array}{l}\text { Table } 21 \text { (Continued). Hydrogen balance for refineries } \\
\text { Entry at top of cell is fuel oil equivalent barrels of hydrogen per day } \\
\text { (minus sign indicates consumption) } \\
\text { Entry at bottom of cell is process unit utilization } \\
\text { (calendar rate divided by stream day capacity x } 100 \text { percent) }\end{array}$} \\
\hline \multirow{2}{*}{ Process } & \multicolumn{3}{|c|}{ Case } \\
\hline & $\begin{array}{c}4 . \\
\text { Reference/PADD } \\
\text { II/Sum }\end{array}$ & $\begin{array}{c}5 . \\
\text { Ether Ban/PADD } \\
\text { II/Sum }\end{array}$ & $\begin{array}{c}6 . \\
\text { Ether Ban/PADD II/Win }\end{array}$ \\
\hline Naphtha hydrotreating & $\begin{array}{c}-3,929 \\
(79)\end{array}$ & $\begin{array}{c}-3,954 \\
(80)\end{array}$ & $\begin{array}{c}-3,774 \\
(75)\end{array}$ \\
\hline $\begin{array}{l}\text { FCC gasoline } \\
\text { desulfurization }\end{array}$ & $\begin{array}{l}-995 \\
(87)\end{array}$ & $\begin{array}{c}-1,040 \\
(91)\end{array}$ & $\begin{array}{l}-963 \\
(83)\end{array}$ \\
\hline Distillate desulfurization & $\begin{array}{c}-12,848 \\
(84)\end{array}$ & $\begin{array}{c}-12,843 \\
(84)\end{array}$ & $\begin{array}{c}-13,514 \\
(84)\end{array}$ \\
\hline Resid desulfurization & $\begin{array}{c}-1,569 \\
(87)\end{array}$ & $\begin{array}{r}-1,569 \\
(87)\end{array}$ & $\begin{array}{r}-1,497 \\
(83)\end{array}$ \\
\hline FCC feed hydrofining & $\begin{array}{l}-6,354 \\
(60)^{\mathrm{a}}\end{array}$ & $\begin{array}{c}-5,533 \\
(53)^{\mathrm{a}}\end{array}$ & $\begin{array}{l}-4,326 \\
(42)^{\mathrm{a}}\end{array}$ \\
\hline Gas oil hydrocracking & $\begin{array}{c}-28,347 \\
(72)\end{array}$ & $\begin{array}{c}-29,721 \\
(75)\end{array}$ & $\begin{array}{c}-26,670 \\
(74)\end{array}$ \\
\hline Reforming & $\begin{array}{c}+44,670 \\
(76)\end{array}$ & $\begin{array}{c}+45,424 \\
(87)\end{array}$ & $\begin{array}{c}+41,386 \\
(70)\end{array}$ \\
\hline C4 isomerization & $\begin{array}{l}-38 \\
(84) \\
\end{array}$ & $\begin{array}{l}-38 \\
(84) \\
\end{array}$ & $\begin{array}{l}-36 \\
(80) \\
\end{array}$ \\
\hline $\mathrm{C} 5 / \mathrm{C} 6$ isomerization & $\begin{array}{l}-434 \\
(84)\end{array}$ & $\begin{array}{l}-434 \\
(84)\end{array}$ & $\begin{array}{l}-414 \\
(80) \\
\end{array}$ \\
\hline Ether production & $\begin{array}{l}-90 \\
(84)\end{array}$ & $\begin{array}{l}0 \\
(0)\end{array}$ & $\begin{array}{l}0 \\
(0)\end{array}$ \\
\hline Hydrogen production & $\begin{array}{c}+23,335 \\
(101)\end{array}$ & $\begin{array}{c}+23,335 \\
(84)\end{array}$ & $\begin{array}{c}+22,224 \\
(80)\end{array}$ \\
\hline $\begin{array}{l}\text { Hydrogen to fuel and } \\
\text { losses }\end{array}$ & $-13,401$ & $-13,627$ & $-12,415$ \\
\hline $\begin{array}{l}\text { a In model, process econor } \\
\text { analysis, this results in lo } \\
\text { would otherwise produce }\end{array}$ & $\begin{array}{l}\text { or high sulfur feed t } \\
\text { zation or retirement } \\
\text { llfur FCC naphthas. }\end{array}$ & $\begin{array}{l}\text { ed FCC naphtha des } \\
\text { ss capacity (e.g., FC }\end{array}$ & $\begin{array}{l}\text { zation. In long-run } \\
\text { d hydrofining) which }\end{array}$ \\
\hline
\end{tabular}


Table 22. Process capacity expansions and additions (MBCD) ${ }^{\mathrm{a}}$

Relative to Reference Cases

\begin{tabular}{|c|c|c|c|c|}
\hline \multirow[b]{2}{*}{ Process } & \multicolumn{4}{|c|}{ Case } \\
\hline & $\begin{array}{c}2 . \\
3 \% \text { vol max } \\
\text { MTBE/PADD } \\
\text { I+III/Sum }\end{array}$ & $\begin{array}{c}3 . \\
3 \% \text { vol max } \\
\text { MTBE/PADD } \\
\text { I+III/Win }\end{array}$ & $\begin{array}{c}5 . \\
\text { Ether } \\
\text { Ban/PADD } \\
\text { II/Sum }\end{array}$ & $\begin{array}{c}6 . \\
\text { Ether } \\
\text { Ban/PADD } \\
\text { II/Win }\end{array}$ \\
\hline Crude distillation & 73 & \multirow{11}{*}{ None } & & \multirow{11}{*}{ None } \\
\hline Naphtha hydrotreating & 53 & & & \\
\hline $\begin{array}{l}\text { FCC naphtha } \\
\text { fractionation }\end{array}$ & & & & \\
\hline $\begin{array}{l}\text { FCC naphtha } \\
\text { desulfurization }\end{array}$ & 65 & & 19 & \\
\hline Reforming & 69 & & & \\
\hline Fluid catalytic cracking & 193 & & & \\
\hline Resid cracking & 31 & & & \\
\hline Alkylation & 26 & & & \\
\hline $\mathrm{C} 5 / \mathrm{C} 6$ isomerization & 26 & & & \\
\hline \multicolumn{2}{|l|}{ Hydrogen plant, FOE } & & & \\
\hline Sulfur, tons per day & 0.4 & & & \\
\hline
\end{tabular}


Table 23. Cost of process capacity expansions and additions $(\$ M M)^{\text {a }}$

Relative to Reference Cases

\begin{tabular}{|c|c|c|c|c|}
\hline \multirow{2}{*}{ Process } & \multicolumn{4}{|c|}{ Case } \\
\hline & $\begin{array}{c}2 . \\
3 \% \text { vol max } \\
\text { MTBE/PADD } \\
\text { I+III/Sum }\end{array}$ & $\begin{array}{c}3 . \\
3 \% \text { vol max } \\
\text { MTBE/ } \\
\text { PADD } \\
\text { I+III/Win }\end{array}$ & $\begin{array}{c}5 . \\
\text { Ether } \\
\text { Ban/PADD } \\
\text { II/Sum }\end{array}$ & $\begin{array}{c}6 . \\
\text { Ether } \\
\text { Ban/PADD } \\
\text { II/Win }\end{array}$ \\
\hline Crude distillation & 131 & \multirow{12}{*}{ None } & & \multirow{12}{*}{ None } \\
\hline Naphtha hydrotreating & 75 & & & \\
\hline $\begin{array}{l}\text { FCC naphtha } \\
\text { fractionation }\end{array}$ & & & & \\
\hline $\begin{array}{l}\text { FCC naphtha } \\
\text { desulfurization }\end{array}$ & 93 & & 32 & \\
\hline Reforming & 217 & & & \\
\hline Fluid catalytic cracking & 939 & & & \\
\hline Resid cracking & 426 & & & \\
\hline Alkylation & 182 & & & \\
\hline $\mathrm{C} 5 / \mathrm{C} 6$ isomerization & 142 & & & \\
\hline \multicolumn{2}{|l|}{ Hydrogen plant, FOE } & & & \\
\hline Sulfur, tons per day & 103 & & & \\
\hline $\begin{array}{l}\text { Land, buildings, catalyst, } \\
\text { chemical, spares, } \\
\text { environmental, other }\end{array}$ & 233 & & 3 & \\
\hline Total & 2,541 & 0 & 35 & 0 \\
\hline
\end{tabular}

${ }^{a}$ Investment decisions are based on a 15 percent discounted cash flow return on investment. 
Table 24. Components of refinery cost changes (cents per gallon of RFG)

Relative to Reference Cases

\begin{tabular}{|c|c|c|c|c|}
\hline & \multicolumn{4}{|c|}{ Case } \\
\hline & $\begin{array}{c}2 . \\
3 \% \text { vol max } \\
\text { MTBE/PADD } \\
\text { I+III/Sum }\end{array}$ & $\begin{array}{c}3 . \\
\text { 3\% vol max } \\
\text { MTBE/PADD } \\
\text { I+III/Win }\end{array}$ & $\begin{array}{c}5 . \\
\text { Ether } \\
\text { Ban/PADD } \\
\text { II/Sum }\end{array}$ & $\begin{array}{c}6 . \\
\text { Ether } \\
\text { Ban/PADD } \\
\text { II/Sum }\end{array}$ \\
\hline $\begin{array}{l}\text { Raw material costs and } \\
\text { product revenue } \\
\text { changes }^{\mathrm{a}}\end{array}$ & -1.5 & \multirow{5}{*}{$\begin{array}{c}\text { No Base } \\
\text { Case }\end{array}$} & +1.6 & \multirow{5}{*}{$\begin{array}{c}\text { No Base } \\
\text { Case }\end{array}$} \\
\hline Processing costs & +0.7 & & -1.5 & \\
\hline Capital charges & +2.0 & & +0.1 & \\
\hline Fixed operating costs & +0.7 & & +0.05 & \\
\hline $\begin{array}{l}\text { Total cost change } \\
\text { (10 percent } \mathrm{ROI})\end{array}$ & +1.9 & & +0.3 & \\
\hline
\end{tabular}

Table 25. Quality of crude oil

\begin{tabular}{|c|c|c|c|}
\hline \multirow[t]{2}{*}{ Property } & \multicolumn{3}{|c|}{ Case } \\
\hline & $\begin{array}{c}1 . \\
\text { Reference/PADD } \\
\text { I+III/Sum }\end{array}$ & $\begin{array}{c}2 . \\
3 \% \text { vol max } \\
\text { MTBE/PADD } \\
\text { I+III/Sum }\end{array}$ & $\begin{array}{c}3 . \\
3 \% \text { vol max } \\
\text { MTBE/PADD } \\
\text { I+III/Win }\end{array}$ \\
\hline Sulfur content, wt $\%$ & 1.34 & 1.34 & 1.34 \\
\hline Gravity, ${ }^{\circ} \mathrm{API}$ & 30.9 & 30.9 & 30.9 \\
\hline
\end{tabular}


Table 25 (Continued). Quality of crude oil

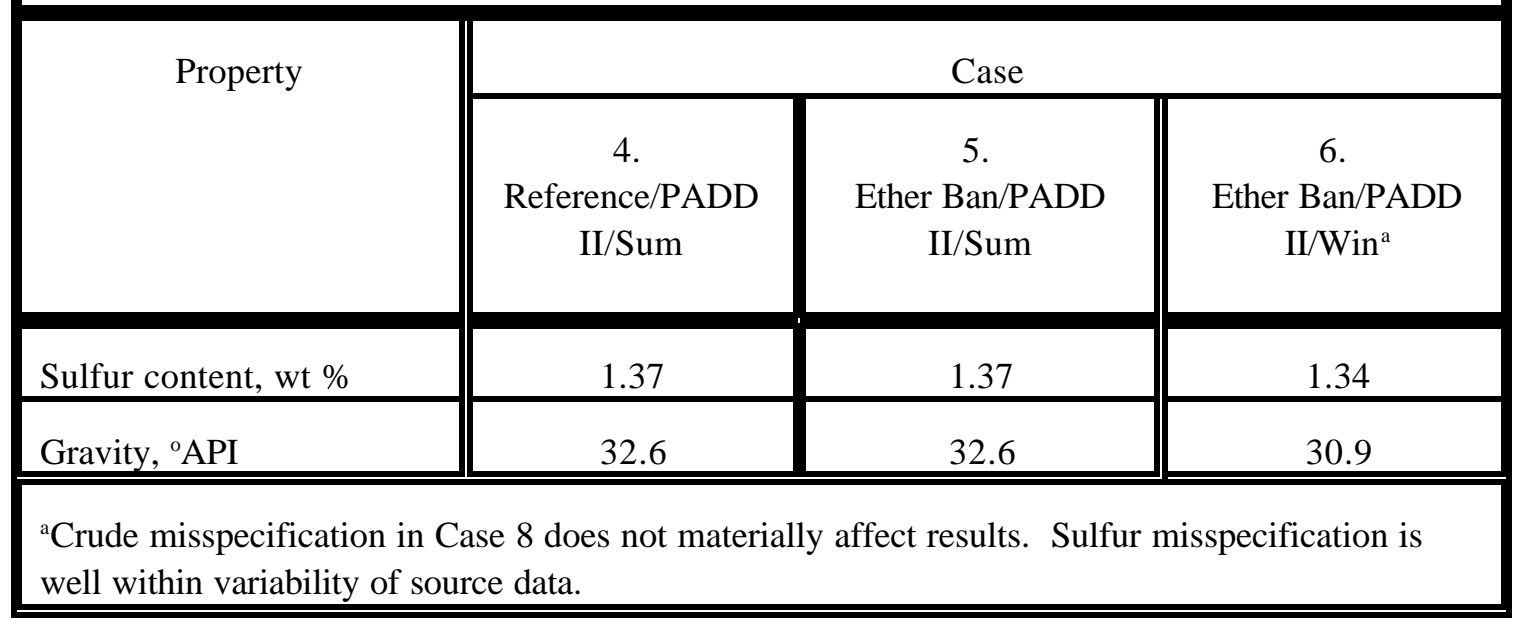

Fig. 2. Ethanol demand in Reference case PADD I+III gasoline type production Year 2006 summer - 30 ppm sulfur in gasoline

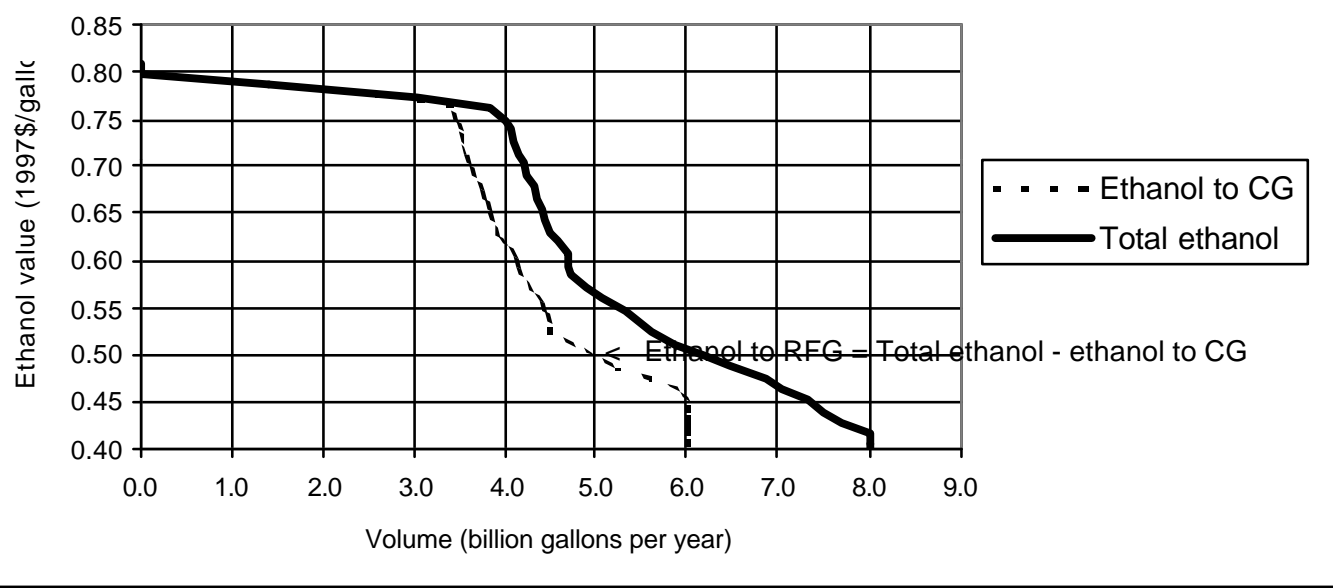

hydrogen balances, example process utilizations, investments, refinery cost changes, and crude oil qualities.

\subsection{PADD I+III, SUMMER WITH 3 PERCENT MAXIMUM MTBE}

MTBE is the dominant oxygenate in RFG produced in PADD I+III refineries. DOE (U.S. DOE, 1994) has shown that, without an oxygen use requirement, refiners would still choose to use a significant amount of oxygen in gasoline. A more recent PADD I study (Hadder, 2000) estimates that MTBE use without an oxygenate requirement would 
not be much less than current use, suggesting that gasoline production has evolved to depend on the attractive octane and volatility characteristics of MTBE. DOE has reported that elimination of MTBE (280,000 thousand barrels per day) is equivalent to a loss of up to 400,000 barrels per day of gasoline production, which is about 5 percent of the U.S. gasoline supply and equivalent to the output of four to five large refineries (Mazur, 2000). A substantial portion of lost gasoline production is due to the octane-yield trade-offs for replacement blendstocks (Hadder, 2000).

Allowing a small percentage of MTBE in gasoline could have significant benefits. A 3 vol percent limit on MTBE would reduce the likelihood for MTBE/water contact; increase the ethanol market; give refiners the option for limited use of MTBE to achieve octane and summer volatility targets and increased flexibility in the transition from winter to summer; and provide greater assurance of adequate gasoline supplies. The solid line in Fig. 3 shows the demand curve for ethanol used in PADD I+III summer gasoline production with 3 vol percent maximum MTBE and no minimum oxygen requirement. At $\$ 1.02$ per gallon (the price responsive value), ethanol demand is $0.9 \mathrm{BGY}$, compared

with zero demand in the summer Reference case. With the limitation on MTBE, ethanol demand is substantially higher than the summer Reference case demand until the ethanol value falls to $\$ 0.76$ per gallon, below which the demand curves are similar.

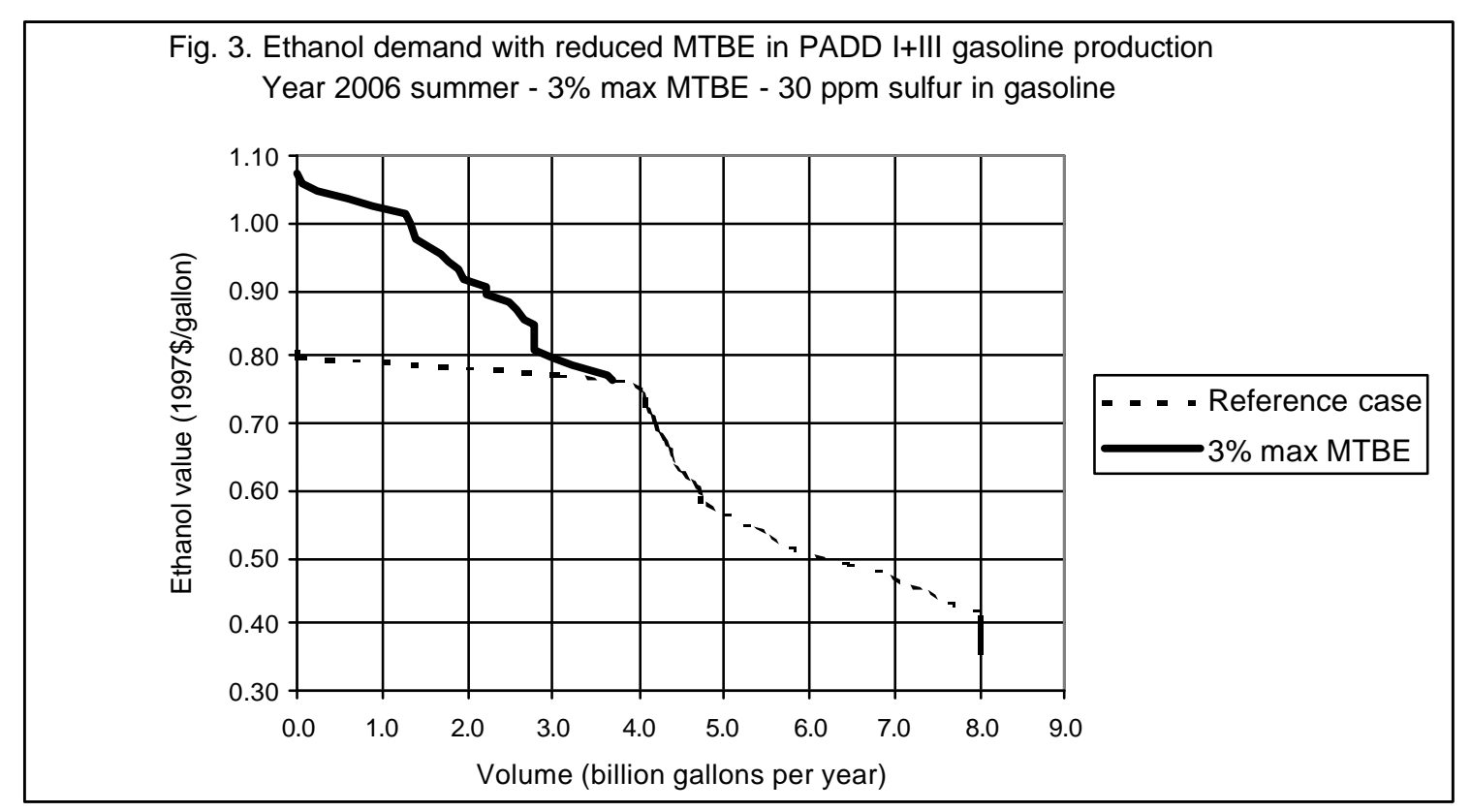

Tables 17 through 22 show key processing and blending impacts. The MTBE volume loss is compensated by increased ethanol blending and increased processing of crude oil and other raw materials, principally purchased gas oil. With increased crude and gas oil processing, there is an increase in FCC naphtha, which has to be desulfurized to satisfy the gasoline sulfur 
specification. The MTBE octane loss is compensated by increased percentages of ethanol, isomerate, and alkylate blended to gasoline. Capacity expansions are required for processes including crude distillation, FCC, FCC naphtha desulfurization, alkylation, isomerization, and sulfur recovery. Reformer expansion increases reformate octane, at some expense of yield. Increased TAP emissions, related to reformate blending, takes up all the summer Reference case slack (in gasolines with some giveaway beyond the no backsliding requirement in the TAP constraints).

The reduction of MTBE results in a cost increase of 1.9 cents per gallon of RFG (Table 24), with investment being the largest component of cost increase. Total investment is $\$ 2.5$ billion, or about $\$ 30$ million per refinery, on average. Compared to a ban, a 3 percent allowance for blending MTBE to gasoline substantially reduces refining costs. Based on marginal costs, the cost of a ban would be at least 3.1 cents per gallon of RFG. For comparison, the MathPro study (MathPro, 2000) estimates the cost of an MTBE ban in PADD I+III, with no TAP backsliding, and with no oxygen requirement, at 3 cents per gallon of summer RFG and oxygenated gasoline.

Marginal costs show that the major contributors to increased costs for reduced use or ban of MTBE are control of octane, volatility, and TAP. For example, Fig. 4 shows how much greater the octane value becomes when the allowable MTBE is reduced to 3 percent.

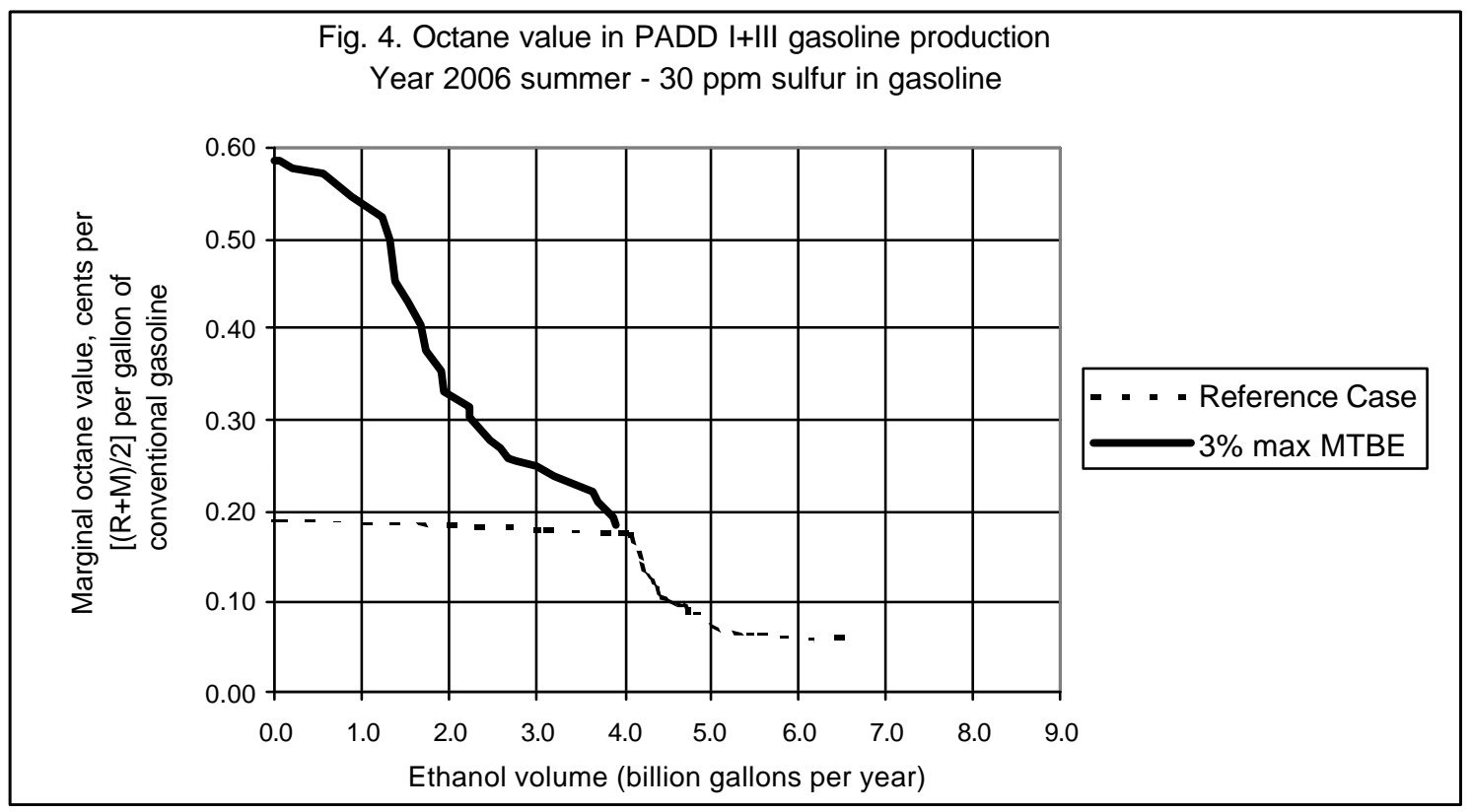

\subsection{PADD I+III, WINTER WITH 3 PERCENT MAXIMUM MTBE}

The solid line in Fig. 5 shows the demand curve for ethanol used in PADD I+III winter gasoline production with 3 vol percent maximum MTBE. At $\$ 0.84$ per gallon (the price 
responsive value), ethanol demand is $0.2 \mathrm{BGY}$, considerably lower than the summer ethanol demand of $0.9 \mathrm{BGY}$ at its price-responsive value of $\$ 1.02$ per gallon. When ethanol value falls below $\$ 0.65$ per gallon, then the winter ethanol demand exceeds summer demand until gasolines are at the maximum allowable limits for ethanol.

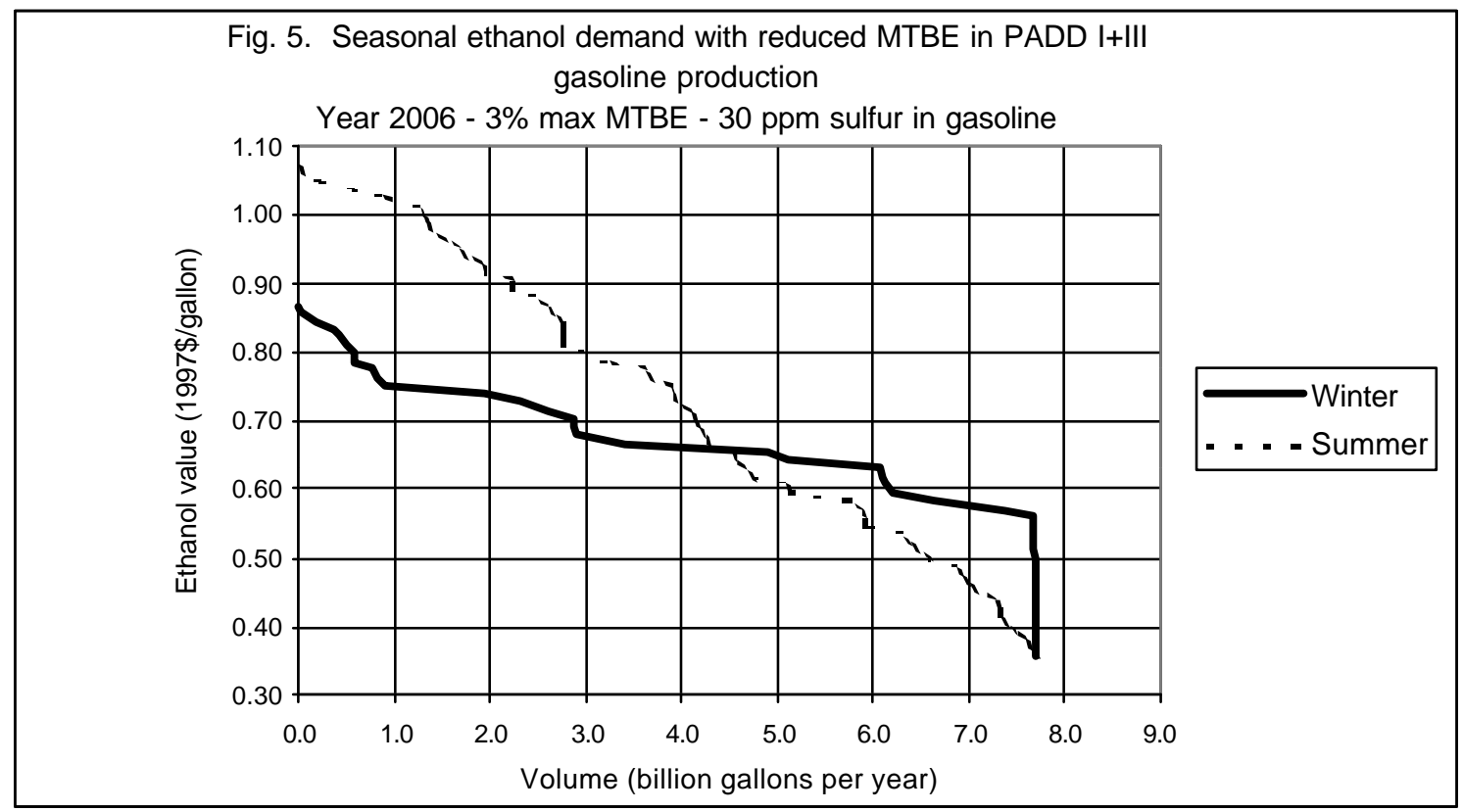

Among the factors that explain the seasonal differences in ethanol demand is the low sulfur requirement for gasoline. Sulfur reduction and octane numbers are more costly in summer than in winter. Winter gasoline blending takes advantage of substantial butane blending to maintain octane and control sulfur. Fig. 6 shows how the seasonal demands change if there is no requirement for low sulfur gasoline. Compared to Fig. 5, the differences in season demand have been significantly reduced at higher ethanol values.

As MTBE is reduced, more $\mathrm{C} 4 \mathrm{~s}$ (butane and related 4-carbon molecules) become available. Because of high vapor pressure, $\mathrm{C} 4 \mathrm{~s}$ can be blended into winter gasoline but not into summer gasoline. Absent conversion of MTBE plants to production technologies that utilize isobutylene, ethanol is the primary substitute for MTBE in the summer.

However, in the winter, ethanol may have to compete with directly-blended C4s. Fig. 7 shows how $\mathrm{C} 4$ blendstocks increase as ethanol value increases. These results suggest that a reduction of MTBE may not have an equivalent increase in ethanol demand in the wintertime. 

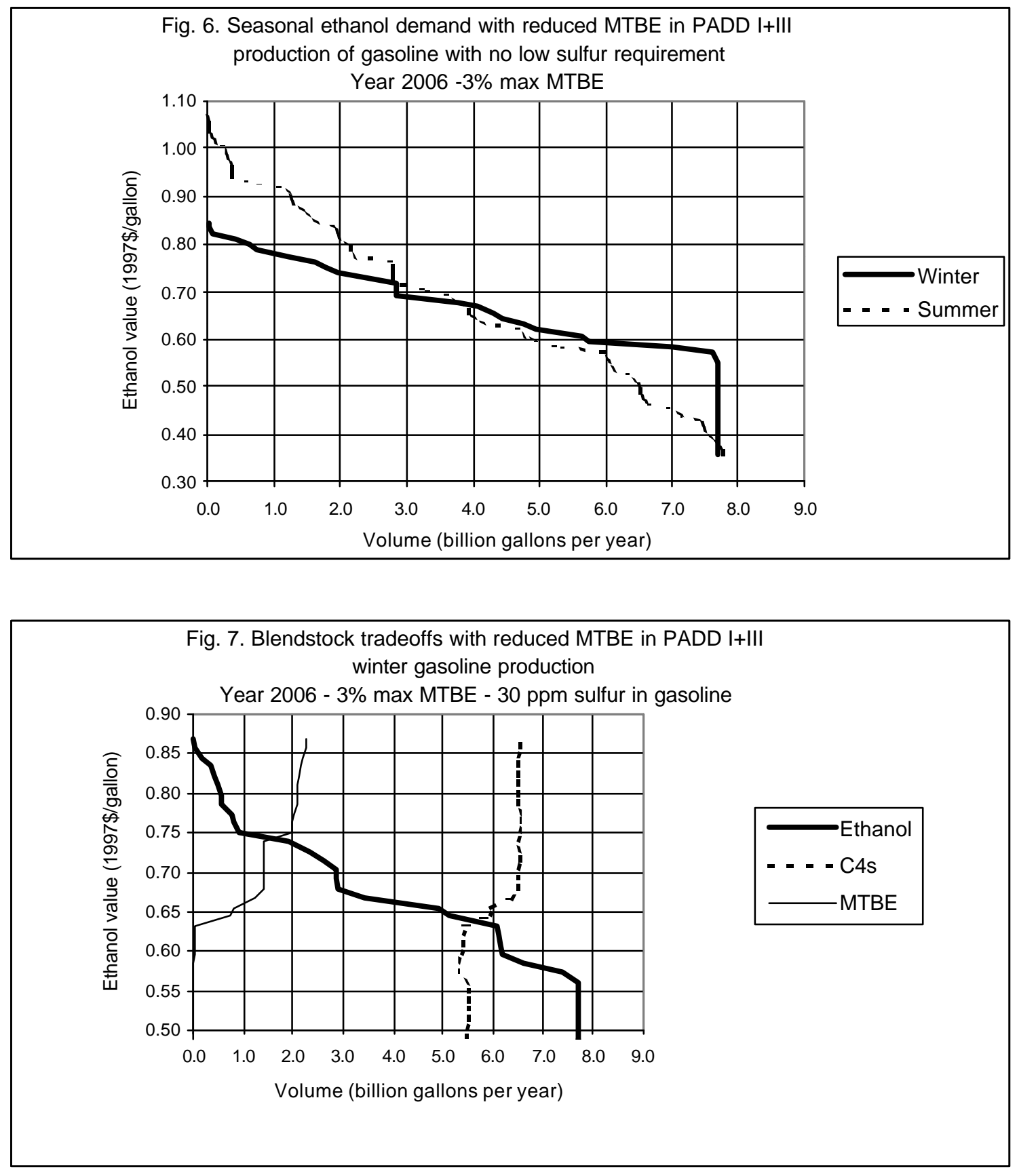

\subsection{PADD I+III, ANNUAL WITH 3 PERCENT MAXIMUM MTBE}

It is assumed that the summer season is 5.5 months long and the winter season is 6.5 months long. With due consideration for different season lengths and different gasoline production within seasons, Fig. 8 shows the annualized demand for ethanol used in PADD I+III gasoline production, with 3 percent maximum MTBE. 


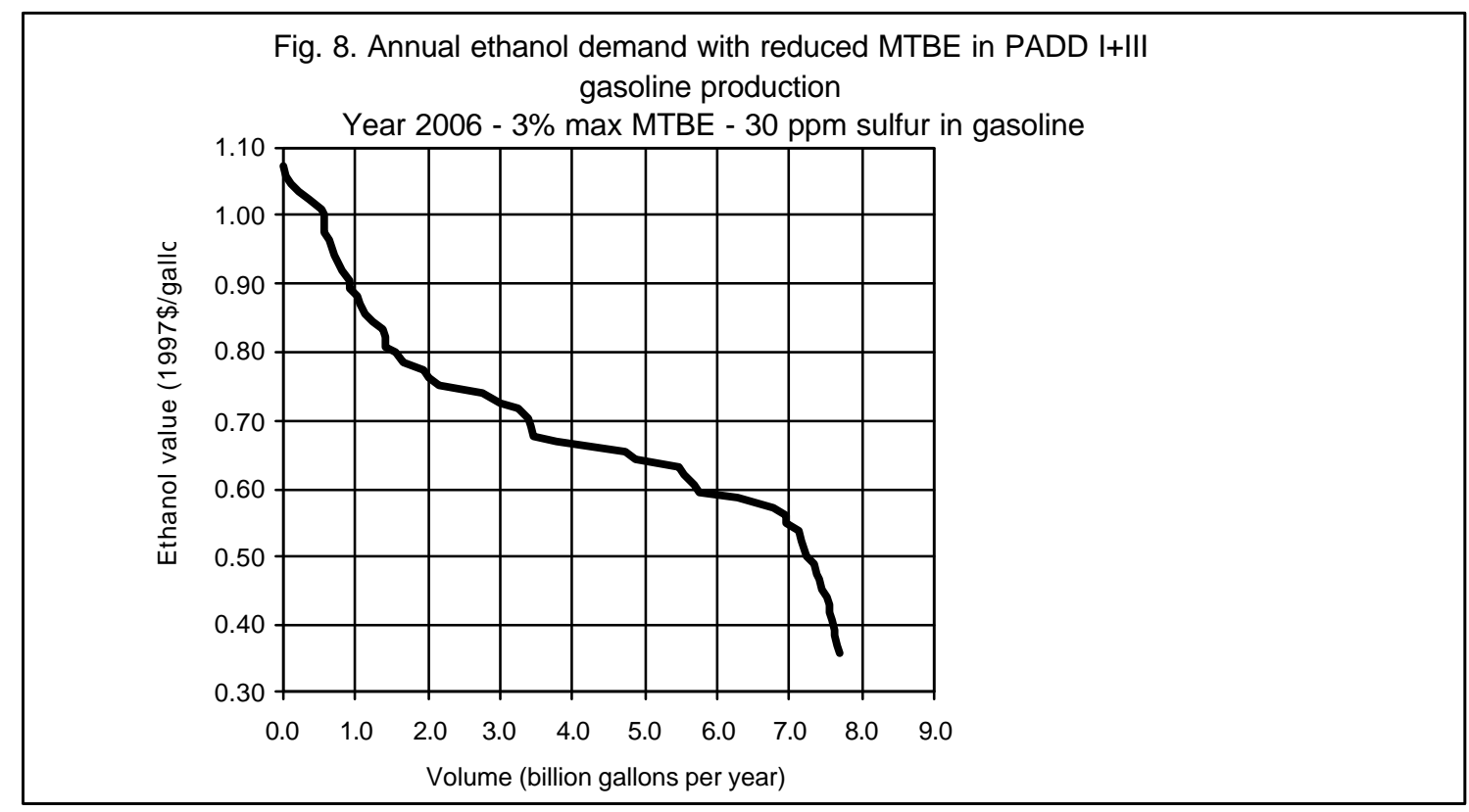

Fig. 9 shows that, with 3 percent maximum MTBE, CG is the source of greater demand for ethanol over the entire range of ethanol values. At $\$ 0.40$ per gallon, with gasolines containing almost the maximum allowable $10 \mathrm{vol}$ percent of ethanol, RFG accounts for 24 percent of total ethanol demand in gasoline blending. The disaggregation of demand in Fig. 9 will be useful in mapping ethanol production into ethanol demand regions, characterized on the basis of ozone non-attainment.

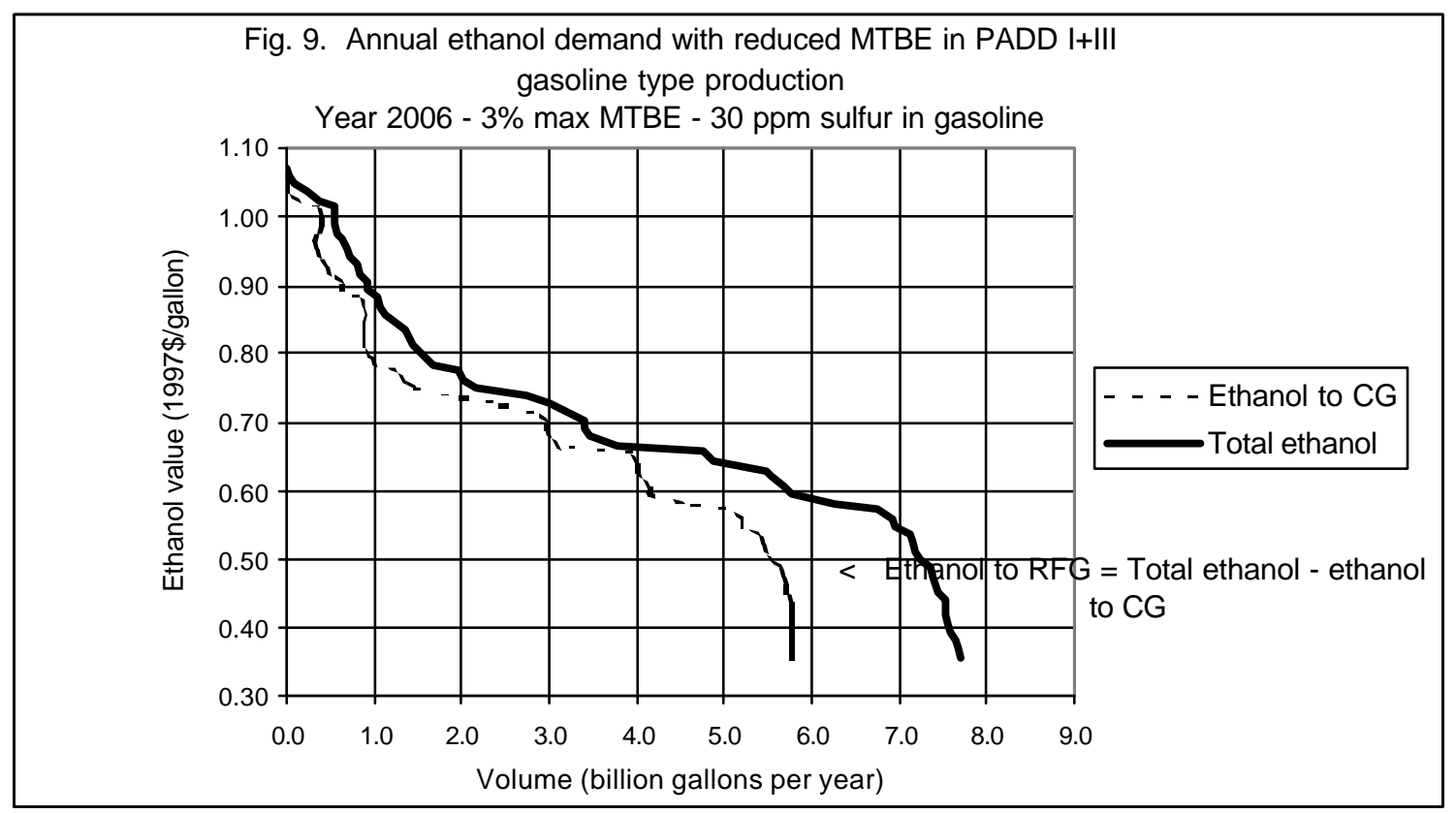




\subsection{PADD II, SUMMER REFERENCE CONDITIONS}

PADD II is a 15 state area in the U.S. Midwest. This study assumes that PADD II has 29 operable refineries which produce 23 percent of all gasoline manufactured in the United States.

The solid line in Fig. 10 shows the ORNL-RYM estimate of the demand curve for ethanol used in PADD II gasoline production in year 2006 for summer reference conditions. At $\$ 0.72$ (the price responsive value), ethanol demand is 1.2 BGY. Ethanol demand is $3.2 \mathrm{BGY}$ at refiner values below $\$ 0.58$ per gallon, and the ethanol concentration in the total gasoline pool is $10 \mathrm{vol}$ percent. Fig. 10 shows how demand for MTBE, at a constant price, decreases as the price of ethanol falls. With an elastic MTBE price, the demand for MTBE would be greater and the demand for ethanol would be lower than shown in Fig. 10, as the value of ethanol falls. Marginal cost results for this PADD II case suggest that volatility limits make summer RFG more difficult to produce with high-RVP oxygenates like ethanol; ethanol's value in CG is enhanced by the 1 psi RVP waiver for 10 vol percent ethanol blends; and the demand for ethanol increases with reductions in allowable sulfur in gasoline (given the yield and octane losses premised for the model's gasoline sulfur reduction technologies).

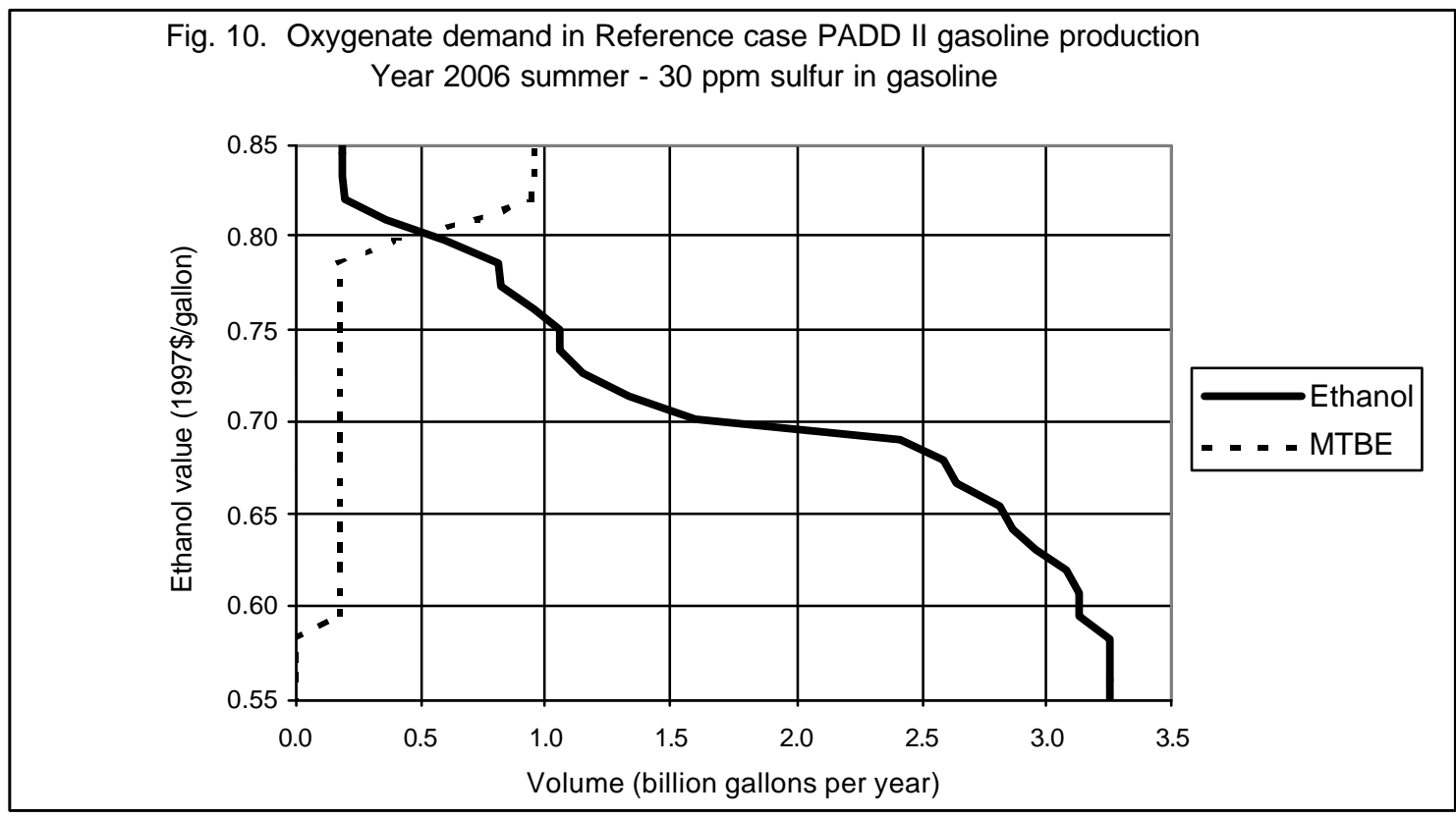

Fig. 11 shows that, for summer Reference conditions, $\mathrm{CG}$ provides the greatest demand potential for ethanol over the entire range of ethanol values. At $\$ 0.58$ per gallon, gasolines contain the maximum allowable $10 \mathrm{vol}$ percent of ethanol, and RFG accounts for 17 percent of total ethanol demand in gasoline blending. The disaggregation of demand in Fig. 11 will be useful in mapping ethanol production into ethanol demand regions, characterized on the basis of ozone non-attainment. 
Fig. 11. Ethanol demand in Reference case PADD II gasoline type production Year 2006 summer - 30 ppm sulfur in gasoline

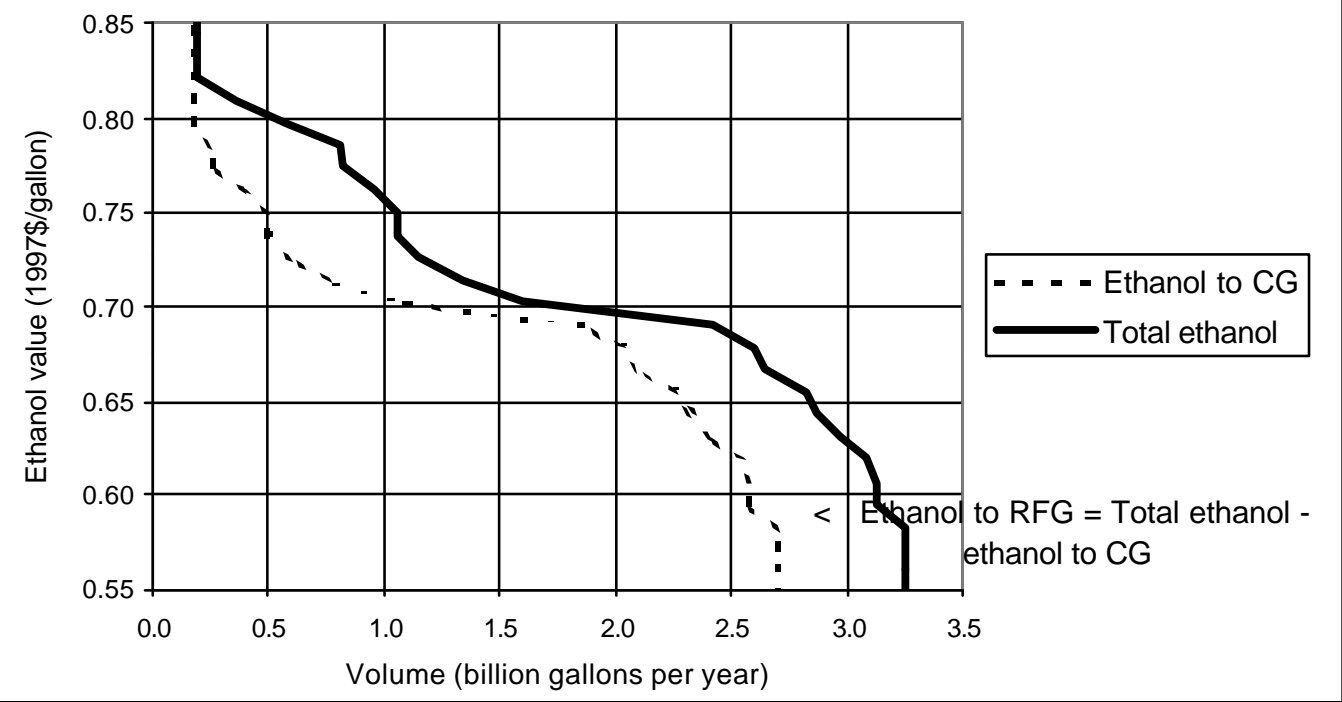

\subsection{PADD II, SUMMER WITH MTBE BAN}

PADD II has the highest regional use of ethanol. Ethanol is at least 90 percent of the total oxygenate volume now blended to gasoline in PADD II. Furthermore, the production share of RFG in PADD II is a relatively low 17 percent. Therefore, over some of ethanol's value range, an MTBE ban should not result in substantially different ethanol demand compared to either the summer Reference case or to a 3 vol percent MTBE case. In fact, in Fig. 10, the Reference case curves below $\$ 0.78$ per gallon are identical to curves for a 3 vol percent maximum MTBE case. Below this value of ethanol in the summer Reference case, MTBE used in any gasoline is less than 3 vol percent.

The dashed line in Fig. 12 shows the demand curve for ethanol used in PADD II summer gasoline production with an MTBE ban. At $\$ 0.73$ per gallon (the price responsive value), ethanol demand is $1.3 \mathrm{BGY}$, compared with 1.2 $\mathrm{BGY}$ at the price responsive value $(\$ 0.72)$ in the summer Reference case. With the MTBE ban, ethanol demand is substantially higher than the summer Reference case demand until the value of ethanol falls below $\$ 0.72$ per gallon, where the ethanol volume in the ban is slightly higher until its concentration reaches $10 \mathrm{vol}$ percent. The demand curve at or below the price responsive value suggests that there will be little difference in ethanol demand in a 3 vol percent MTBE case and an MTBE ban case.

Tables 17 through 22 show key processing and blending impacts. The MTBE volume loss is compensated by increased processing of crude oils and increased ethanol blending. The MTBE octane loss is compensated by increased percentages of ethanol and by higher-octane reformate blended to gasoline. The severity of reformer operation has 


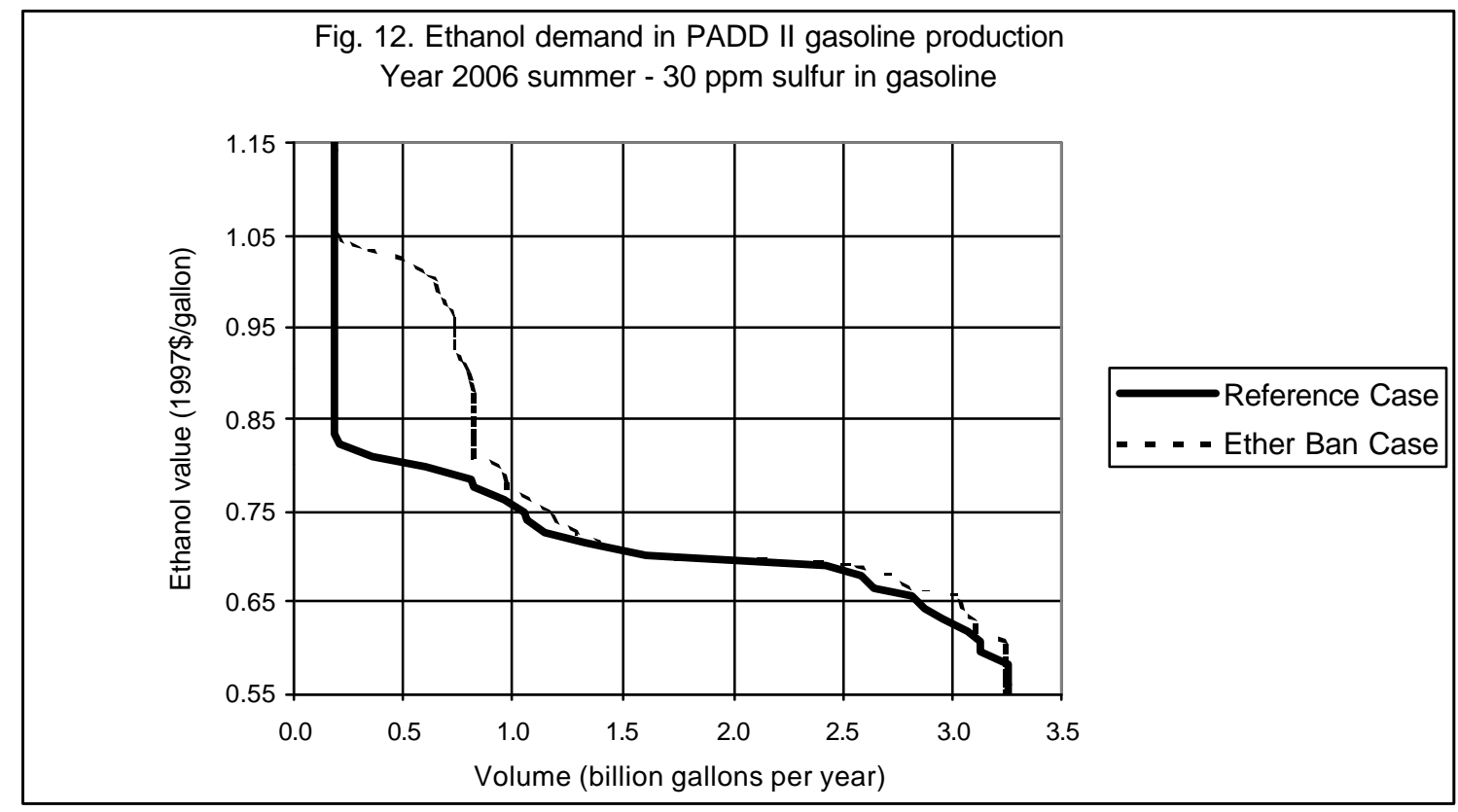

increased, with a 2 percent increase in pool Research Octane Number, and a 1 percent increase in pool aromatics. Reformate has lower vapor pressure and sulfur content compared with alkylate. There is a substantial increase, compared to the summer Reference case, in reformate blended to RFG premium with ethanol; the TAP property of this gasoline has headroom to accommodate additional reformate, which has higher TAP emissions than alkylate. Isobutylene is diverted from the shut-down ether plant to alkylation. Nevertheless, because of the strategy to maintain octane with reformate (taking advantage of vapor pressure and sulfur benefits), there is a slight reduction in alkylate blended to the gasoline pool, and a substantial reduction of alkylate blended to RFG premium with ethanol. Lastly, with the increase in crude oil processing, a small capacity expansion is required for FCC naphtha desulfurization.

At the price-responsive cost, the MTBE ban results in a cost increase of 0.3 cents per gallon of RFG (Table 24), with raw materials being the largest component of cost increase. For a 3 vol percent MTBE case, there would be no cost increase since the case would be identical to the Reference case.

\subsection{PADD II, WINTER WITH MTBE BAN}

The solid line in Fig. 13 shows the demand curve for ethanol used in PADD II winter gasoline production with an MTBE ban. At $\$ 0.71$ per gallon (the price responsive value), ethanol demand is 1.4 BGY, compared with summer demand of $1.3 \mathrm{BGY}$ at $\$ 0.73$ per gallon. As discussed in Section 5.2, as MTBE is reduced, more C4s become available. Because of high vapor pressure, $\mathrm{C} 4 \mathrm{~s}$ can be blended into winter gasoline but not into summer gasoline. In the 
summer, the primary substitute for MTBE is ethanol. However, in the winter there are two substitutes for MTBE: C4s and ethanol. As previously noted, a reduction of MTBE may not have an equivalent increase in ethanol demand in the wintertime.

With a sufficiently low refiner value, ethanol should be preferred over $\mathrm{C} 4 \mathrm{~s}$ in winter, and one would expect winter demand for ethanol to be higher than summer demand. However, Fig. 13 shows that demand for ethanol is lower in the winter than in the summer, even at low ethanol values. Among the factors that explain the seasonal differences in ethanol demand is the low sulfur requirement for gasoline. Sulfur reduction and octane numbers are more costly in the summer, and less costly in the winter. Among other factors, winter blending takes advantage of significant butane blending to maintain octane and control sulfur. Fig. 14 shows how the relative seasonal demands change if there is no requirement for low sulfur gasoline. Compared to Fig. 13 , the differences in seasonal demand have been greatly reduced, with reversed seasonal importance in some parts of the demand curves.

Fig. 13. Ethanol demand with MTBE ban in PADD II gasoline production Year 2006 - 30 ppm sulfur in gasoline

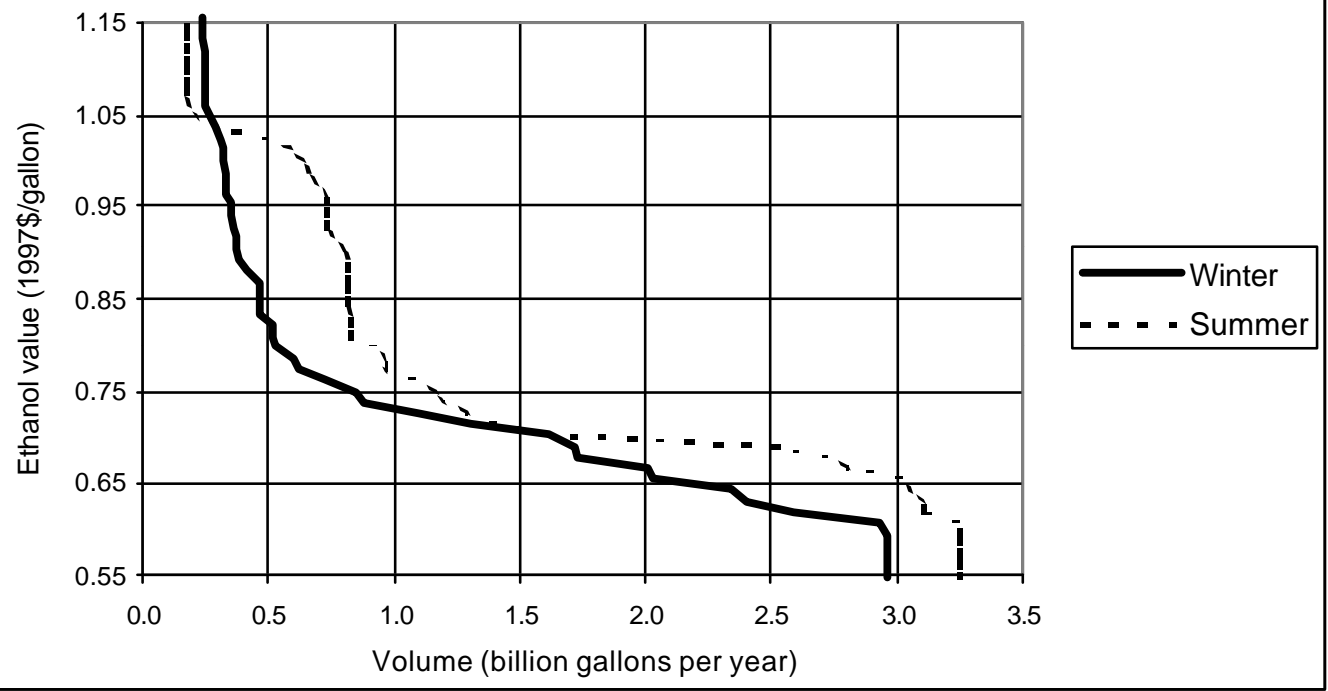

\subsection{PADD II, ANNUAL WITH MTBE BAN}

It is assumed that the summer season is 5.5 months long and the winter season is 6.5 months long. With due consideration for different season lengths and different gasoline production within seasons, Fig. 15 shows the annualized demand for ethanol used in PADD II gasoline production in year 2006 with an MTBE ban. CG is the greater source of demand for ethanol at values below $\$ 0.75$ per gallon and above $\$ 1.02$ per gallon. In the $\$ 0.75$ to $\$ 1.02$ per gallon range, RFG is the source of greater demand for ethanol. At an ethanol value of $\$ 0.35$ per gallon, with gasolines containing the maximum 
Fig. 14. Seasonal ethanol demand with MTBE ban in PADD II gasoline production Year 2006 - no low sulfur requirement for gasoline

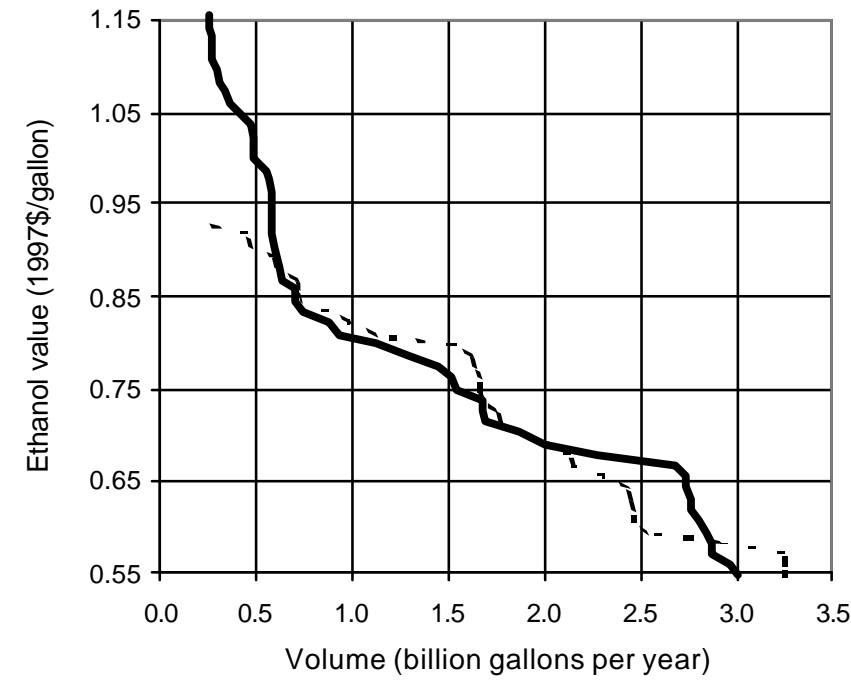

Winter ethanol demand - - - - Summer ethanol demand

Fig. 15. Annual ethanol demand with MTBE ban in PADD II gasoline production Year 2006 - 30 ppm sulfur in gasoline

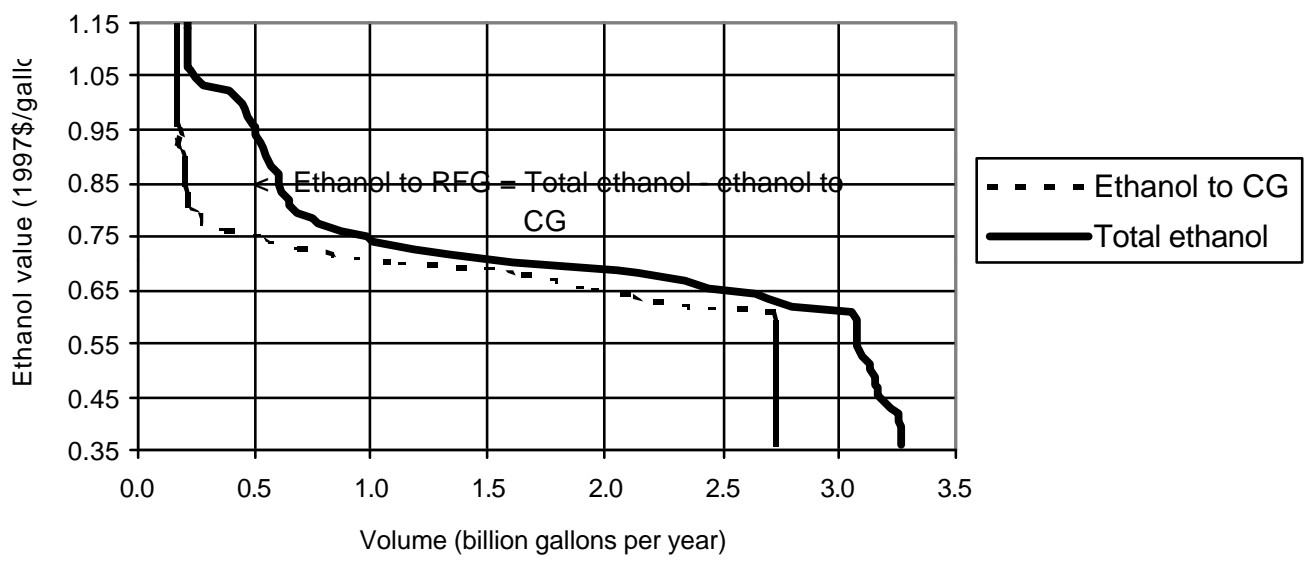

allowable 10 vol percent of ethanol, RFG accounts for 17 percent of total ethanol demand in gasoline blending. The disaggregation of demand in Fig. 15 will be useful in mapping ethanol production into ethanol demand regions, characterized on the basis of ozone non-attainment. 


\section{CONCLUSIONS}

Ethanol competes with MTBE to satisfy oxygen, octane, and volume requirements of certain gasolines. However, the water quality problems caused by MTBE appear to have expanded the market opportunities for ethanol. The use of MTBE in the RFG program has resulted in growing detections of MTBE in drinking water, with between 5 percent and 10 percent of community drinking water supplies in high oxygenate use areas showing at least detectable amounts of MTBE. There have been important debates about the air quality benefits and water quality problems of MTBE. In November, 1998, the U.S. EPA Administrator appointed a Blue Ribbon Panel to investigate the air quality benefits and water quality concerns associated with oxygenates in gasoline, and to provide advice and recommendations on ways to maintain air quality while protecting water quality. Given the Panel recommendations, the EPA Administrator announced that "We must begin to significantly reduce the use of MTBE in gasoline as quickly as possible without sacrificing the gains we've made in achieving cleaner air."

Reduction or elimination of the use of MTBE would increase the costs of gasoline production and possibly reduce the gasoline output of U.S. refineries. MTBE is the dominant oxygenate in RFG, and gasoline production has evolved to depend on the attractive octane and volatility characteristics of MTBE. DOE has reported that elimination of MTBE is equivalent to a loss of up to 5 percent of the U.S. gasoline supply.

The potential gasoline supply problems of an MTBE ban could be mitigated by allowing a modest 3 vol percent maximum MTBE in all gasoline. Compared to a ban, the 3 vol percent MTBE option results in costs that are 40 percent less than an MTBE ban in PADD I+III. Major contributors to costs for a ban of MTBE are control of octane, volatility, and prevention of TAP backsliding.

The winter demand for ethanol may not be as high as expected with a reduction of MTBE use. Absent conversion of MTBE plants to production technologies that utilize isobutylene, ethanol is the primary substitute for MTBE in the summer. However, in the winter, ethanol may have to compete with directly-blended $\mathrm{C} 4 \mathrm{~s}$.

In a region with already high use of ethanol, an MTBE ban might have minimal effect on the ethanol demand curve, unless gasoline producers in other regions bid away the local supply of ethanol. PADD II has the highest regional use of ethanol, which provides at least 90 percent of the total oxygenate volume now blended to gasoline in PADD II. Furthermore, the production share of RFG in PADD II is relatively low. Consequently, a reduction in MTBE does not 
substantially change ethanol demand in PADD II. An MTBE ban in PADD II results in a cost increase of only 0.3 cents per gallon of RFG.

The ethanol/MTBE issue gained momentum in March 2000 when the Clinton Administration released a "legislative framework to encourage immediate Congressional action to reduce or eliminate MTBE and promote renewable fuels like ethanol. The legislative framework being sent to Congress includes the following three recommendations, which taken together as a single package, provide an environmentally sound and cost effective approach: First, Congress should amend the Clean Air Act to provide the authority to significantly reduce or eliminate the use of MTBE. This step is necessary to protect America's drinking water supplies. Second, as MTBE use is reduced or eliminated, Congress must ensure that air quality gains are not diminished. The Clinton-Gore Administration is deeply committed to providing Americans with clean air and clean water. Third, Congress should replace the existing oxygenate requirement in the Clean Air Act with a renewable fuel standard for all gasoline. By preserving and promoting continued growth in renewable fuels, particularly ethanol, this step will increase farm income, create jobs in rural America, improve our energy security, and help protect the environment (U.S. EPA, 2000)."

While the case studies described in this report were performed prior to March 2000, the study premises are consistent with the Administration announcement, and the ethanol demand curve estimates of this study can be used to evaluate the impact of the Administration principles and related policy initiatives. 


\section{REFERENCES}

(API/NPRA) American Petroleum Institute and National Petroleum Refiners Association. (1997). 1996 American Petroleum Institute/National Petroleum Refiners Association Survey of Refining Operations and Product Quality, API Publishing Services, $1220 \mathrm{~L}$. Street, N.W., Washington, DC, July.

Anderson, R.C., T.J. Lareau, and R.D. Wollstadt. (1988). The Economics of Gasoline Ethanol Blends, Research Study \#045, American Petroleum Institute, Washington, DC, November.

Andress, David and Gerald R. Hadder. (1999). Ethanol Demand in U.S. Gasoline Production, Office of Fuels Development, U.S. Department of Energy, http://www.ott.doe.gov/pdfs/lowble 1.pdf, May.

Hadder, Jerry. (2000). "MTBE Removal Is Equivalent to Loss of Five+ Average US Refineries," memorandum to Barry McNutt of U.S. Department of Energy Office of Policy, Oak Ridge National Laboratory, Oak Ridge, TN, February 24.

Hadder, G.R. (1998). Ethanol Demand in United States Gasoline Production, ORNL6926, Oak Ridge National Laboratory, Oak Ridge, TN, November 24.

Korotney, D. (1993). Revised Complex Model for Conventional and Reformulated Gasoline, EPA Air Docket A-92-12, Environmental Protection Agency, Fuels and Standards Branch, Ann Arbor, MI.

MathPro. (2000). Refining Economics of MTBE Ban and 1200 DI Standards, P.O. Box 34404, West Bethesda, MD, March 15.

Mazur, Mark J. (2000). Statement Before Committee on Agriculture, Nutrition and Forestry, United States Senate, April 11.

(NPC) National Petroleum Council. (1993). U.S. Petroleum Refining, Washington, DC, August.

(NPRA) National Petroleum Refiners Association. (1991). NPRA Survey of U.S. Gasoline Quality and U.S. Refining Industry Capacity to Produce Reformulated Gasolines, Part A, Suite 1000, 1899 L Street, NW, Washington, DC, January. 
(NESCAUM) Northeast States for Coordinated Air Use Management. (1999). RFG/MTBE Findings \& Recommendations, http://www.nescaum.org/pdf/MTBE_PH2/Ph2summ.pdf, August.

Oil \& Gas Journal. (1999). "Panel urges less MTBE use in gasoline," PennWell Publishing Company, Tulsa, OK, p. 35, August 2.

O'Keefe, B. (1999). Panel Calls for Action to Protect Water Quality While Maintaining Air Benefits from National Clean Burning Gas, The Blue Ribbon Panel on Oxygenates in Gasoline, http://www.epa.gov/OMS/consumer/fuels/oxypanel/blueribb.htm, July 27.

Radler, Marilyn. (1998). "1997 Worldwide Refining Survey," Oil \& Gas Journal, December.

Radler, Marilyn. (1999). "Worldwide Construction," Oil \& Gas Journal, April 19.

Tallett, M.R., and D.N. Dunbar. (1988). Enhancement of EIA Refinery Yield Model:

Extension and Demonstration on Gasoline and Diesel Quality Issues, Oak Ridge National Laboratory Contract No. DE-AC05-840R21400, EnSys Energy \& Systems, Inc., Flemington, NJ, August.

Tallett, M.R., D.N. Dunbar, and J. Leather. (1992). Summary Documentation of Oak Ridge Refinery Yield Model Reformulated Gasoline Update, EnSys Energy \& Systems, Inc., Flemington, NJ, March 16.

(TMS) Technology \& Management Services, Inc. (1998). Ethanol Industry Evolution Systems Analysis Spreadsheet (ESAS), Documentation and User's Manual, Gaithersburg, MD, December 1.

(U.S. DOE) U.S. Department of Energy (DOE), Energy Information Administration. (1999a). Petroleum Supply Annual 1998, DOE/EIA-0340(99)/1 and 2, http://www.eia.doe.gov/oil_gas/petroleum/pet_frame.html, Washington, DC.

(U.S. DOE) U.S. Department of Energy, Energy Information Administration. (1999b). Annual Energy Outlook 1999, DOE/EIA-0383(99), http://www.eia.doe.gov/oiaf/aeo99/aeo99tables/aeo99b.pdf, Washington, DC.

(U.S. DOE) U.S. Department of Energy (DOE), Energy Information Administration. (1999c). Petroleum Marketing Annual, DOE/EIA-0380(98), http://www.eia.doe.gov/oil_gas/petroleum/pet_frame.html, Washington, DC.

(U.S. DOE) U.S. Department of Energy (DOE), Energy Information Administration. (1999d). Refinery Capacity Data, DBF file containing petroleum refinery capacity data by refinery. Energy Information Administration (EIA), Form EIA-820, "Biennial Refinery Report," 
http://www.eia.doe.gov/oil_gas/petroleum/data_publications/refinery_capacity_data/refcapacity .html.

(U.S. DOE) U.S. Department of Energy. (1994). Estimating the Costs and Effects of Reformulated Gasolines, DOE/PO-0030, Washington, DC, December.

(U.S. DOE) U.S. Department of Energy. (1984a). Refinery Evaluation Modeling System (REMS) Documentation, DOE/EIA-0460, Energy Information Administration, Washington, DC, October.

(U.S. DOE) U.S. Department of Energy. (1984b). Refinery Evaluation Modeling System (REMS) Documentation, DOE/EIA-0461, Energy Information Administration, Washington, $\mathrm{DC}$, October.

(U.S. EPA) U.S. Environmental Protection Agency. (2000). Headquarters Press Release, "Clinton-Gore Administration Acts to Eliminate MTBE, Boost Ethanol," http://yosemite.epa.gov/opa/admpress.nsf/b1ab9f485b098972852562e7004dc686/2054b28bf 155afaa852568a80066c805?OpenDocument, Washington, DC, March 20.

(U.S. EPA) U.S. Environmental Protection Agency. (1999). Achieving Clean Air and Clean Water: The Report of the Blue Ribbon Panel on Oxygenates in Gasoline, EPA420-R-99021, http://www.epa.gov/OMS/consumer/fuels/oxypanel/blueribb.htm\#Recommendation, September 15 .

(U.S. EPA) U.S. Environmental Protection Agency. (1994). "Regulation of Fuel and Fuel Additives: Standards for Reformulated Gasoline: Final Rulemaking," Federal Register, 7716-7878, February 16.

(U.S. GAO) U.S. General Accounting Office. (1997). Effects of the Alcohol Fuels Tax Incentives, GAO/GGD-97-41, Washington, DC, March. 


\section{INTERNAL DISTRIBUTION}

1. G.E. Courville

2. T.R. Curlee

3. J. H. Cushman

4. M.E. Downing

5. A. R. Ehrenshaft

6. R. L. Graham

7. D.L. Greene

8-32. G. R. Hadder

33. P. S. Hu

34. P. Leiby
35. S. B. McLaughlin

36. C.I. Moser

37. R. D. Perlack

38. R.B. Shelton

39. M.E. Walsh

40. L.L. Wright

41-43. Central Research Library

44. Document Reference Section

45-47. Laboratory Records

48. Laboratory Records--RC

\section{EXTERNAL DISTRIBUTION}

49. L. A. Abron, President, PEER Consultants, P.C., 1460 Gulf Blvd., $11^{\text {th }}$ Floor, Clearwater, Florida 34630

50. S. L. Cutter, Director, Hazards Research Lab, Department of Geography, University of South Carolina, Columbia, SC 29208

51. S. G. Hildebrand, Director, Environmental Sciences Division, Oak Ridge National Laboratory, Post Office Box 2008, Oak Ridge, Tennessee 37831-6037

52. P. R. Rittelmann, FAIA, Executive Vice President, Burt Hill Kosar Rittelmann Associates, 400 Morgan Center, Butler, Pennsylvania 16001-5977

53. S. F. Tierney, The Economic Resource Group, Inc., One Mifflin Place, Cambridge, Massachusetts 02138

54. C. M. Walton, Ernest H. Cockrell Centennial Chair in Engineering and Chairman, Department of Civil Engineering, University of Texas at Austin,E Cockrell, Jr. Hall I, Suite 4210, Austin, Texas 78712-1075

55-64. OSTI, U.S. Department of Energy, P.O. Box 62, Oak Ridge, Tennessee 37831

65. D. Andress, David Andress \& Associates, Inc., 11008 Harriet Lane, Kensington, Maryland 20895

66. J. E. Ferrell, EE-31, U.S. Department of Energy, Forrestal Building, 1000 Independence Avenue, S.W., Washington, DC 20585

67. J.R. Hettenhaus, CEA, Inc., 3211 Trefoil Drive, Charlotte, North Carolina 28226.

68. R.W. King, Director, Environmental Fuels Technology, Sun Company, Inc., 10 Penn Center, 1801 Market Street, Philadelphia, Pennsylvania 19103-1699

69. R. LeGassie, Technology \& Management Services, Inc., 18757 North Frederick Road, Gaithersburg, Maryland 20879

70. M. Leister, Marathon Ashland Petroleum LLC, Fuels Technology, 539 Main Street, Findlay, Ohio 45840 
71. B. McNutt, PO-62, Room 7H-021, U.S. Department of Energy, Forrestal Building, 1000 Independence Avenue, S.W., Washington, DC 20585

72. T.D. Nguyen, EE-31, U.S. Department of Energy, Forrestal Building, 1000

Independence Avenue, S.W., Washington, DC 20585

73. C. Prakash, 24 Hyde park Way, Nepean, Ontario K2G 5R4, Canada

74. R.E. Reynolds, Downstream Alternatives, Inc., P.O. Box 2587, South Bend, Indiana 46614

75. D. Santini, Argonne National Laboratory, Center for Transportation Research, Building 362 2B, 9700 S. Cass Avenue, Argonne, Illinois 60439

76. G. Santos-Leon, EE-31, U.S. Department of Energy, Forrestal Building, 1000 Independence Avenue, S.W., Washington, DC 20585

77. J. Sheehan, National Renewable Energy Laboratory, 1617 Cole Boulevard, Golden Colorado 80401

78. M. Singh, Argonne National Laboratory, 955 L'Enfant Plaza, SW, Suite 6000, Washington, DC 20024-2168

79. K.S. Tyson, National Renewable Energy Laboratory, 1617 Cole Boulevard, Golden Colorado 80401

80. M. Q. Wang, Argonne National Laboratory, 9700 S. Cass Avenue, Argonne, Illinois 60439

81. R. Wooley, National Renewable Energy Laboratory, 1617 Cole Boulevard, Golden Colorado 80401

82. S. Zukor, Technology \& Management Services, Inc., 18757 North Frederick Road, Gaithersburg, Maryland 20879 